ROSE MARA GOZZI

\title{
Oficina de Informação: conhecimento e cultura na Educação Infantil
}

Dissertação apresentada à Área de Concentração: Ciência da Informação e Documentação, da Escola de Comunicações e Artes da Universidade de São Paulo, como exigência parcial para a obtenção do Título de Mestre em Ciências da Comunicação, sob a orientação do Prof. Dr. Edmir Perrotti 
ROSE MARA GOZZI

\section{Oficina de Informação: conhecimento e cultura na Educação Infantil}

Dissertação apresentada à Área de Concentração: Ciência da Informação e Documentação, da Escola de Comunicações e Artes da Universidade de São Paulo, como exigência parcial para a obtenção do Título de Mestre em Ciências da Comunicação, sob a orientação do Prof. Dr. Edmir Perrotti

\section{São Paulo}

2005 
Oficina de Informação: conhecimento e cultura na Educação Infantil

Candidata: Rose Mara Gozzi

Orientador: Prof. Dr. Edmir Perrotti

Banca

Defendida em de de 2005. 
À minha filha Bia e meus sobrinhos, Tiago e Felipe.

Aos educadores, pesquisadores e profissionais de diversos setores que lutam para garantir o direito à cidadania plena das crianças.

A todas as crianças que têm o direito de se apropriar dos dispositivos de informação. 
Ao Nelson, meu pai, que me ensinou a importância da responsabilidade e do compromisso com o trabalho. A ele, também, o reconhecimento por financiar uma grande parte dos meus estudos, mesmo não compreendendo o seu significado na minha vida profissional.

À Dalva, minha mãe, que me ensinou a brincar com as pessoas através das palavras inventadas na sua infância, e pela sua sensibilidade em acolher a mim e a Bia, no momento em que mais precisei.

Ao Florindo, meu avô, que me ensinou a ser transparente nas relações humanas.

À Alessandra, minha irmã querida, e meu cunhado Airton, que sempre estiveram ao meu lado, proporcionando infra-estrutura para sonhos se realizarem, entre eles, esta dissertação.

À Bia, minha filha, que, com grande sabedoria $e$ pouca idade, compreendeu minha ausência em alguns momentos de sua vida. Foi de sua existência, Bia, que ganhei forças para lutar pela vida. 


\section{Agradecimentos}

Ao Prof. Edmir, orientador firme, rigoroso e, ao mesmo tempo, generoso, que me ensinou, além do conhecimento acadêmico, a acreditar na parceria entre pesquisa e serviço. Com você, Mestre, aprendi a arte de buscar significado na vida, seja qual for a idade.

Às professoras Emília Cipriano e Marina Célia Dias, pelo carinho e sugestões feitas no exame de qualificação.

À Iara Mattos, vice-Coordenadora da COSEAS, por apostar num projeto de parceria entre serviço e pesquisa, fundamental à realização deste trabalho.

À Maria Clotilde, Tuta, Diretora da Divisão de Creches, cuja atuação profissional representa um incentivo à inovação e aos estudos, minha admiração pela implantação, na USP, de um Projeto inovador de Creches e pelo estímulo à formação de técnicos, possibilitando vínculos com espaços acadêmicos. Sua generosidade transcende a vida profissional, e esteve sempre ao meu lado, lendo, relendo e corrigindo os meus inúmeros textos.

À Maria Claudia, amiga, parceira de coordenação da Creche/Pré Escola Oeste, que dividiu comigo as angústias, dúvidas, receios e alegrias de elaborar um trabalho acadêmico. Você, Cacau, ensinou-me que a vida deve ser vivida intensamente.

À Claire, amiga, parceira de coordenação da Creche/Pré Escola Oeste, pela escuta atenta e carinhosa das minhas lamentações em momentos de 
dificuldades; juntas, colhemos os frutos de sementes plantadas a várias mãos.

À Célia Serrão, amiga, colega de trabalho no curso de pedagogia, pela grande generosidade, carinho, socorro e acolhida nos momentos de crise, mostrando caminhos possíveis para essa produção acadêmica. Você, Célia, ensinou-me a lutar por uma Educação Infantil de qualidade, além dos muros da Universidade.

À Denise, amiga, companheira de reflexões, por mostrar a existência de outras possibilidades na minha vida.

À Mariana, amiga prestativa que sempre esteve presente, acolhendo-me nos momentos de dificuldades.

Aos estudantes do curso de Pedagogia da FAAC, pela paciência e carinho.

À Stela, amiga que incentivou e contribuiu para meu ingresso no mestrado, pela dedicação e competência nas correções realizadas e observações relevantes sugeridas na revisão deste trabalho.

À Kamila, pela sua generosidade e dedicação nos momentos de elaboração final desta dissertação, auxiliando-me com sua competência na área de informática.,

À Toninha, pela cuidado nas relações humanas e disponibilidade na revisão desta dissertação. 
Aos redatores dos depoimentos: pesquisadores da Equipe do PROESI, mães, adolescentes, educadores e funcionários da Creche/Pré Escola Oeste, pela disponibilidade e tempo empregado.

Às bolsistas: Toninha, Cíntia, Bia, Adriana, Cris, Adriana Dias, Eva Carolina e às educadoras: Valéria, Samantha, Marionice e Ana Helena, pela energia que colocaram na realização do projeto, e pelas marcas deixadas na Oficina de Informação.

Aos protagonistas que atuaram e atuam na Creche/Pré Oeste: equipes da cozinha, limpeza, enfermagem, zeladoria, secretaria, coordenação, educadores, pais e, principalmente, às crianças, que contribuíram de várias formas, mostrando caminhos para a construção de um dispositivo de informação, em Educação Infantil. 


\section{Resumo}

Este trabalho tem como objetivo refletir sobre a importância de dispositivos de informação, nos processos educativos de Educação Infantil.

O estudo foi realizado na Oficina de Informação, dispositivo informacional implantado na Creche/Pré Escola Oeste, localizada no campus da USP, na cidade de São Paulo, em parceria da COSEAS/Divisão de Creches com o PROESI - Programa Serviços de Informação em Educação, da ECA/USP.

A experiência vivida como coordenadora pedagógica na Creche/ Pré Escola Oeste, assim como a pesquisa, possibilitaram a constatação da importância da criação de novos dispositivos informacionais na Educação Infantil contemporânea, proporcionando um novo olhar sobre a pedagogia da infância e a conviç̧ão de que esse tipo de dispositivo de informação não é "um luxo", mas uma necessidade dos novos tempos.

Palavras-chave: dispositivo de informação; formação; Educação; Cultura, desconfinamento; biblioteca; infância. 


\section{ABSTRACT}

This piece of work has the objective of a reflective thinking about the information devices, in educational processes of Infant \& Kindergarten Education.

The study was performed at the Information Workshop, informational device implemented at the Day Care Center/Preschool Oeste, located at the campus of USP, in the City of São Paulo, with the partnership of COSEAS/ Day Care Center Division and ECA/USP'S PROESI - Education Information Services Program.

The experience lived as pedagogic coordinator at the Day Care Center/Preschoo Oeste, as well as the research, have made possible the confirmation of the importance of creating new informational devices in the Infant \& Kindergarten Contemporary Education; providing a new look over Chilhood Pedagogy and the conviction that this type of information device is not a "luxury", but a necessity of the new times.

Key-words: information device; formation; Education; Culture; release; library; childhood. 


\section{SUMÁRIO}

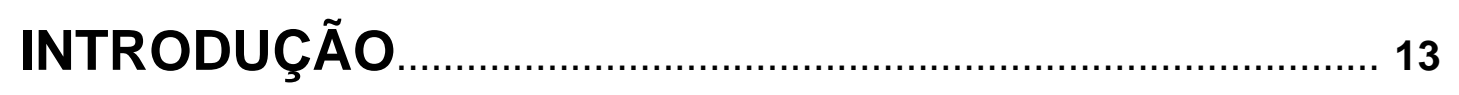

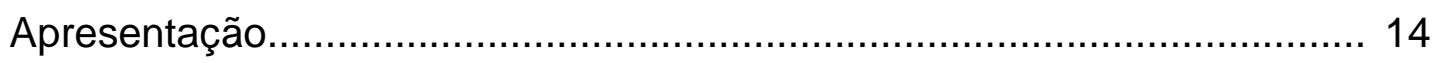

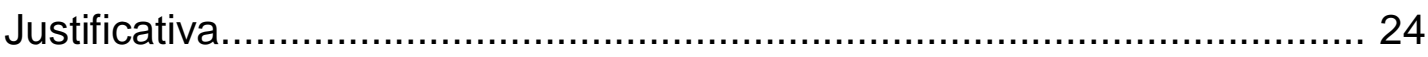

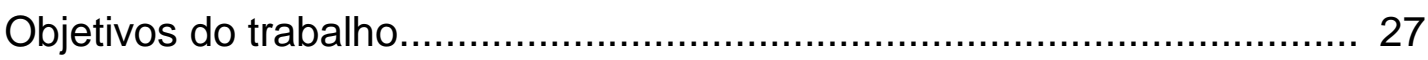

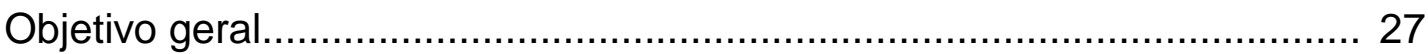

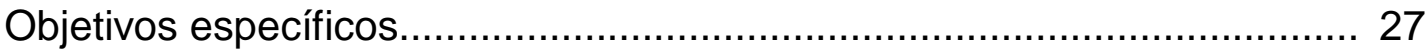

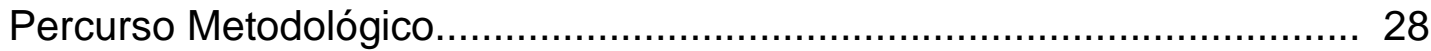

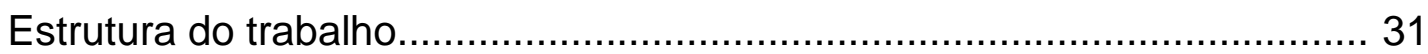

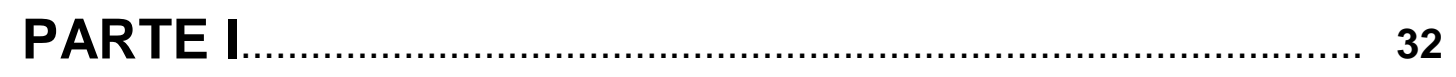

1 - Informação, Educação, Cultura e Infância: possíveis relações............... 33

1.1 - Dispositivos de informação ........................................

1.2 - Oficina de Informação: mediação e apropriação cultural................. 36

1.3 - Novas relações entre Informação e Educação Infantil................... 38

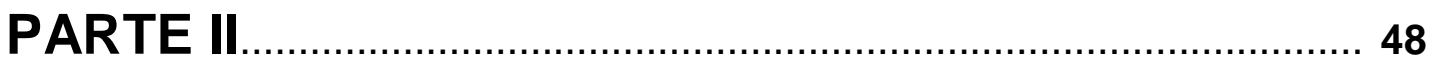

2 - O contexto da pesquisa.................................................................. 49

2.1 - Creches da Universidade de São Paulo: breve histórico................ 49

2.2 - A Creche/Pré Escola Oeste.......................................................... 51

2.3 - Implicações no Espaço Físico da Creche/Pré Escola Oeste........... 52

2.4 - Proposta Pedagógica da Creche/Pré Escola Oeste........................ 57

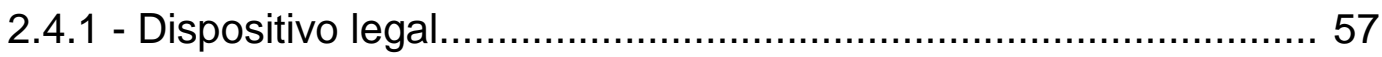

2.4.2 - Concepção da Creche/ Pré Escola Oeste............................... 58

2.4.3 - Estrutura / Funcionamento................................................... 59

2.4.4 - Projetos que envolvem os diversos grupos de crianças........ 66

2.4.5 - Recursos Humanos............................................................. 70

2.5 - Dispositivos de Informação da Creche/Pré Escola Oeste.............. 77

2.5.1 - A primeira Biblioteca da Creche/Pré Escola Oeste................ 77

2.5.2 - Descrevendo o objeto de pesquisa: Oficina de Informação... 80 
2.5.3 - Mudanças na Oficina de Informação...................................... 98

2.5.4 - Assumindo a Oficina de Informação...................................... 103

2.5.5 - A Creche/Pré Escola Oeste responsabilizando-se integralmente pela Oficina de Informação.................................................. 106

2.5.6 - Pastas-memória: exemplo de resultados............................... 108

2.5.7 - Ampliação do atendimento.................................................. 111

2.5.8 - Dez anos de Oficina de Informação....................................... 124

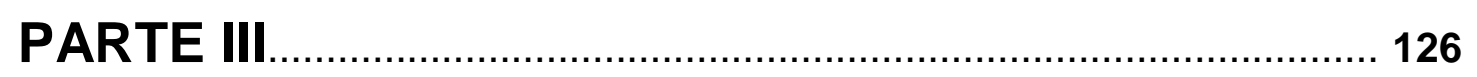

3 - Diálogo com os depoimentos......................................................... 127

3.1 - Depoimentos de Usuários........................................................... 128

3.2 - Depoimentos de pesquisadores.................................................. 143

3.3 - Depoimentos de Funcionários.................................................... 175

PARTE IV

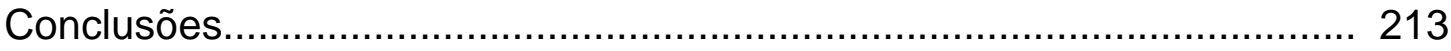

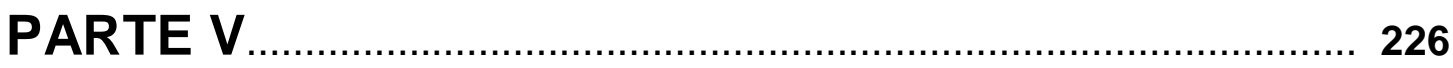

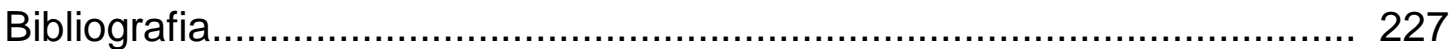




\section{Lista de llustração}

FIGURA 1 - (1974) Os perigos de um turno integral pleno na escola

FIGURA 2 - Personagens da história "A galinha ruiva" para colorir

FIGURA 3 - Boletim informativo "Ofinforma"

FIGURA 4 - Cartão produzido pelas crianças da Escola Alô-Alô 
INTRODUÇÃO 


\title{
Apresentação
}

\begin{abstract}
Falar das próprias experiências formadoras é, pois, de certa maneira, contar a si mesmo a própria história, as suas qualidades pessoais e socioculturais,

o valor que se atribui ao que é "vivido" na continuidade temporal do nosso ser psicossomático. Contudo, é também um modo de dizermos que, neste continuum temporal, algumas vivências têm uma intensidade particular que se impõe à nossa consciência e dela extrairemos as informaçôes úteis às nossas transações conosco próprio el ou com o nosso ambiente humano e natural.
\end{abstract}

Marie-Christine Josso

Eu havia terminado o colegial. Não sabia como continuar os meus estudos. Tampouco qual seria a minha profissão, como milhares de jovens que vivem esse dilema no Brasil. Minha mãe, acompanhando a indecisão, sugeriu uma profissão: o magistério. Não aceitei sua sugestão, talvez só para contrariá-la. Ela insistia com coisas do tipo: "Professora é a melhor profissão para mulher. Após o casamento poderá continuar trabalhando, é possível conciliar os afazeres domésticos e os cuidados com os filhos". E mais acrescentou, a partir de sua experiência como aluna: "as professoras têm a possibilidade de realizar trabalhos manuais, como tricô, na própria sala de aula, quando os alunos estiverem copiando os pontos na lousa; é uma profissão impar". Mas, apesar de tantas "vantagens", eu ainda não estava convencida.

Como Dona Dalva, minha mãe, seu Nelson, meu pai, que se orgulhava por possuir um salário digno, sem ao menos ter terminado o primário, dizia: "Prá que servem 
os estudos? O que importa é dinheiro no bolso". Essa frase ouvi por toda a minha meninice.

Diante do quadro, resolvi buscar o meu primeiro emprego, em "escolinhas" de Educação Infantil. Acreditava que, para isso, não havia necessidade de habilitação e, talvez, àquela altura, estivesse certa.

Depois de enviar o meu currículo para todas as escolas do bairro, fui chamada para trabalhar em uma delas; fiquei responsável por uma sala com 10 crianças de 5 anos. Comentei com a dona da escola que não sabia por onde começar e ela tranqüilizou-me, dizendo: "Não precisa se preocupar; aqui trabalhamos com apostilas que você precisa somente aplicar, e passar alguns desenhos no mimeógrafo que as crianças somente colorirão." Pensei: desenhos mimeografados conheço bem, pois passei vários anos da minha vida escolar pintando-os. Uma das boas lembranças que tenho do Ensino Fundamental, na época do denominado primário, eram as datas comemorativas. Nada de reflexão sobre qualquer assunto, mas de praxe tínhamos que colorir as famosas folhas mimeografadas. E mais, as melhores pinturas iam para o quadro de honra. E lá estavam sempre os meus trabalhos, que me custavam uma grande dor no dedo e bons calos.

Já nos primeiros dias de trabalho, durante o recreio, tive a possibilidade de conversar com algumas professoras e percebi que elas tinham um conhecimento específico sobre assuntos da Educação Infantil. A convivência com as crianças foi me encantando cada vez mais e, nesse processo, fui me dando conta de que precisava de mais formação. Resolvi, então, me matricular no magistério, apesar de já ter terminado o colegial. Como dizia minha mãe, eu era realmente teimosa. Só que, dessa vez, eu desejava fazer o curso.

Nos primeiros dias de aula, fui tocada especialmente por disciplinas como: Filosofia, Sociologia, História da Educação, Metodologia e Didática. Comecei a me 
destacar no colégio como nunca havia acontecido antes. A aluna que, na primeira série, teve dificuldades com alguns conteúdos escolares, reverteu essa situação.

A professora Sueli, percebendo meu interesse pela Educação e meu empenho nas aulas, incentivava-me oferecendo livros com dedicatórias que eu achava encantadoras e ensinava-me a arte de escrever. Eu enfrentava os desafios da leitura e da escrita, encarando a sensação de "fracasso" que me acompanhava desde a $1^{\underline{a}}$ série (com as pesquisas da Emília Ferreiro pude compreender o que explicava o "fracasso" em processo de alfabetização). Parecia que tinha encontrado o meu caminho e ao mesmo tempo a possibilidade de ressignificar momentos vividos no sistema público de ensino.

Trabalhei, em seguida, em uma "escolinha" um pouco maior. Já com alguns conhecimentos sobre Educação, resolvi questionar o Projeto Educacional da Escola, fazendo observações e críticas. No final do ano fui despedida.

Descobri, então, que na USP, muito próximo da minha casa, havia uma creche selecionando educadores. Resolvi me inscrever, junto com a minha amiga Claudina. Em fevereiro de 1988, lá estava eu com um grupo de crianças de 2 anos, na Creche Central, sem nunca ter trocado antes uma fralda de bebê, muito menos planejado atividades para as crianças. Justamente eu, que era contra planejamentos pré - estabelecidos. Estava com medo.

Na época, não havia ainda uma rotina de horário estabelecida na Creche capaz de proporcionar alguma segurança. As novas professoras ficavam sob o ritmo, a orientação e as modulações das educadoras mais antigas, que se revoltavam pela substituição de suas colegas demitidas, por questões políticas da última greve. A formação das educadoras da Creche Central também era diferente das professoras que eu havia encontrado nas escolinhas e no magistério. Eram estudantes de história, filosofia, psicologia, ciências sociais, entre outras 
faculdades da USP. Era tudo muito diferente pra mim, a começar pelos vestuários e até posturas adotadas pelas educadoras.

Diante da situação encontrada, depois de dois dias, havia decidido não ir mais à Creche e procurei a professora Sueli para compartilhar essa decisão. Ela me disse: "Dois dias é muito pouco para decidir algo, você precisa experimentar mais um pouco".

O que realmente estava por detrás dessa decisão? Acredito que estava angustiada com os valores que circulavam pelos espaços da Creche. Pais, educadores, crianças relacionavam-se com o mundo de uma forma que me surpreendia criticar livremente, buscando os seus direitos de cidadãos. Tudo aquilo em que eu acreditava estava bem diante de mim, mas para desfrutar precisava ter coragem.

Para completar, um dia eu estava fazendo uma troca de fraldas, junto com o único educador da Creche, Leonardo - o que para mim já era super complicado, um homem naquele espaço - quando adentrou um garotinha loura de 6 anos perguntando: "Ei, você namora com ele e transa?" Não consigo me lembrar quem respondeu a ela. Só sei que fiquei espantada, pensando como uma criança tão pequena sabia formular perguntas sobre sexo.

Pensava em quais propostas desenvolver com as crianças. Tive a idéia de buscar na minha própria infância e comecei a fazer castelos de areia que soltavam fumaça de verdade pela chaminé, a representar papéis como da bruxa da história de "Branca de Neve e os Sete Anões", etc. Lembro-me de dois momentos da minha interpretação quando tinha 5 anos. O primeiro, da minha fala: "Espelho, espelho meu, existe mulher mais bela do que eu." Outro, após a resposta que dei com grande fúria ao espelho: "Maldita, eu me vingarei."

Com 40 dias de trabalho na Creche, deparei-me com uma grande greve. E lá estava eu, aderindo ao movimento junto com os companheiros. Meus pais ficaram 
indignados com a minha decisão. Que contradição estava vivendo, da doutrina religiosa em que fora criada, ao sindicato dos trabalhadores da USP! Ficava perplexa com as discussões que ocorriam nas assembléias, sentia muito medo de ser novamente despedida, mas, ao mesmo tempo, estava muito orgulhosa de estar lutando por melhores condições de trabalho. Até hoje, ao ouvir o carro de som do sindicato circulando pela USP, revivo aqueles momentos.

Depois de dois anos trabalhando na Creche Central, resolvi cursar Pedagogia. Nesse período, tive a oportunidade de estagiar em uma escola de educação infantil chamada Te-Arte, extremamente diferente dos modelos curriculares brasileiros. As crianças permaneciam na escola somente meio período; tinham a possibilidade de escolher entre diversos ateliês para desenvolver seus trabalhos ou, simplesmente, correr ao redor da escola, ou contemplar os animais: patos, galinhas, cabras. $\mathrm{Na}$ Te-Arte, a brincadeira era considerada o trabalho mais importante da criança.

Achava muito interessante a forma como os educadores faziam as intervenções e, também, como as crianças maiores auxiliavam as menores a subirem e descerem barrancos da escola. A atitude de respeito à criança pequena estava bem perto de mim e era nisso que eu acreditava.

Uma das situações marcantes que vivi na Te-Arte foi o ritual da pinhata, prática aprendida com uma criança mexicana matriculada na escola. Em toda celebração importante, Terezita, a dona da escola, não hesitava em confeccionar junto com as crianças uma pinhata (uma figura oca, feita com estrutura de arame e recoberta com papéis colados) carregada de várias surpresas. Para romper a pinhata, as crianças faziam uma grande roda num "tapete" gramado e cantavam a seguinte música: 
Bate, bate, bate, Não perca a cabeça

Porque se a perde

Perde o caminho

Não quero ouro, não quero prata O que eu quero é romper a pinhata

Que ela rompa!

Depois de alguns meses, a dona da escola me convidou para fazer parte do quadro de professores. Eu, então, tinha que escolher entre a Creche Central e a Te Arte. Optei pela Creche Central, em virtude do vínculo empregatício, e do fato de ali existir, também, liberdade de expressão, permitindo que os educadores construíssem as práticas pedagógicas.

A Creche Central estava passando por mudanças, principalmente no Projeto Educacional coordenado pela nova pedagoga, Rosana. Ela assumia um grande compromisso com a formação dos educadores da época, e havia percebido o meu interesse pela área de Artes Visuais. Quando fui trabalhar com crianças de 4 a 6 anos, fiquei responsável pelo ateliê de artes. Queria compreender como se ensinava e se aprendia artes visuais na Educação Infantil, pois os subsídios teóricos aprendidos no Magistério e na Faculdade de Pedagogia não eram suficientes para o pleno desenvolvimento do trabalho, na prática. Sabia que os desenhos mimeografados não poderiam fazer parte do trabalho, pois desrespeitavam a inteligência e a sensibilidade das crianças.

Tive a oportunidade de conhecer Maria Christina Rizzi e Marina Célia Moraes Dias, educadoras do Museu de Arte Contemporânea da Universidade de São Paulo, que mostraram alguns caminhos para minha formação de arte-educadora. Fui estudar um pouco da História da Arte e encontrei os artistas e seus estilos. Passei a visitar museus e a valorizá-los. A frase: "Isso é Arte? Até eu consigo fazer!" transformou-se em: "O que o artista quer dizer?" De que forma essa obra de arte mexeu comigo?" 
Vivi momentos significativos com as crianças nos ateliês da Creche Central e com os grupos de educadores. Até há pouco tempo atrás, havia algumas marcas dos nossos trabalhos no espaço do módulo III. Ainda guardo os meus seis cadernos de registros sobre os trabalhos desenvolvidos com os grupos. Agora as folhas já estão amareladas, mas guardam histórias de uma jovem educadora de crianças pequenas.

Estava trabalhando há seis anos na Creche Central como educadora, quando foi aberta a seleção para o cargo de pedagoga da Creche Oeste e eu resolvi me inscrever. E passei.

Em novembro de 1993, com 26 anos, sem experiência na função, estava coordenando um grupo de educadoras. Brinco até hoje, que me inscrevi por um impulso, pois, talvez, não teria feito isso se tivesse parado para pensar.

O desafio estava posto - construir uma Proposta Pedagógica com toda a equipe. Que desafio!. trabalhar com um grupo que, no momento, tinha várias questões de relacionamento com a direção da Creche, dentre elas a falta de confiança.

A busca de qualidade na Creche Oeste tornou-se uma meta na minha vida profissional, a qual compartilhei com a nova diretora, Marie Claire. Por onde começar esse trabalho com tantas questões, que iam desde a construção da minha identidade de coordenadora pedagógica, até problemas herdados da gestão anterior. Tive que buscar princípios de honestidade, justiça e transparência que aprendi no âmbito familiar. Esses ingredientes contribuíram para formar minha identidade profissional.

Entre as novidades e questionamentos na nova função, um desafio foi proposto: participar da criação da Oficina de Informação, concebida pela equipe do PROESI (Programa Serviços de Informação em Educação) da ECA/USP (Escola de 
Comunicações e Artes). O projeto consistia na implantação de um espaço de informação e cultura na Creche, com atuação de várias práticas que foram objetos de pesquisas, observações e críticas por parte dos próprios usuários, crianças, pais e funcionários.

Atualmente, a Oficina de Informação é um dispositivo informacional incorporado às práticas e processos da Creche/Pré Escola Oeste. Neste percurso ocorreram várias conquistas. Atualmente estamos colhendo os frutos da parceria.

Em meio a várias demandas, era necessário construir um vínculo de confiança com as equipes da Creche e transformar a imagem negativa que circulava no campus da Universidade e na FEUSP (Faculdade de Educação) acerca da Creche Oeste. Claire e eu, diante de qualquer convite para contar sobre o trabalho da Creche, não hesitávamos, passávamos horas organizando imagens da rotina.

Continuei investindo na minha formação e resolvi fazer um curso de especialização em Artes, na Eca, para organizar os conhecimentos que havia construído nos vários cursos e leituras sobre a área de Artes Visuais.

Lembro-me do primeiro convite, em 1998, para ministrar um curso, no Estado do Ceará, sobre Artes Visuais na Educação Infantil. Eu, que até então não havia saído do entorno de São Paulo, teria que partir para outro Estado. Quase desisti! Mas amigos e as educadoras da Creche incentivaram-me, ajudando a organizar materiais e até confeccionaram um cartão gigantesco desejando sucesso, que me acompanhou na viagem. Depois, recebi uma proposta para organizar uma apostila sobre Artes Visuais para professores leigos do estado do Ceará, fruto das oficinas que havia realizado. Convidei uma grande amiga para escrever comigo, a Andréa, que conheci nos tempos da Creche Central.

No ano de 1997, tive a oportunidade de cursar uma outra especialização, na área de Educação Infantil, oferecida pela FEUSP. Conhecer, então, a abordagem de 
Reggio Emilia contribuiu significativamente para transformar os projetos de trabalho da Creche Oeste.

Participei de várias disciplinas da pós-graduação como aluna ouvinte, mas sempre com o compromisso moral de desenvolver trabalhos de conclusão. Um dia, Francisco, meu companheiro na época, percebendo o meu esforço, falou-me que já estava na hora de preparar um projeto de pós-graduação. Hesitei, mas depois de alguns meses comecei a elaborar essa idéia.

No ano de 2002, fui aceita no Departamento de Biblioteconomia, na ECA para cursar a pós-graduação, agora como aluna regular. Essa entrada no curso de pósgraduação me fez reavivar um momento muito especial da minha infância, um jogo que acontecia entre mim e meu pai. Minha mãe sempre foi evangélica, desde sua infância, e preocupava-se em ensinar a doutrina religiosa dizendo: "Não podemos acreditar nessas mentiras de Coelho da Páscoa e Papai Noel. Mesmo assim, quando encontrava meu pai, eu perguntava: "Pai, foi você que colocou o ovo no meu berço?" Ele dizia: "Eu não". Sentia-me satisfeita com aquela resposta, pois eu queria sonhar, que dentre as várias crianças do mundo, o coelho havia me escolhido para visitar. Agora o sonho acontecia novamente - dentre vários candidatos, eu havia sido escolhida para o curso de pós-graduação. Mas não era sonho: era realidade!

A entrada no mestrado abriu outras portas: ministrar uma disciplina no curso de Pedagogia da FAAC (Faculdade Associada de Cotia), na habilitação de Educação Infantil, onde busquei construir uma metodologia que envolvesse as estudantes de período noturno. Que desafio! Pois, além de estudantes, muitas eram trabalhadoras, donas de casa e mães. No ano de 2005, um grupo de estudantes me convidou, junto à professora Célia, para orientar o TCC (Trabalho de Conclusão de Curso) referente à biblioteca na Educação Infantil. 
No $2^{0}$ semestre de 2004, quase terminando o mestrado, assumo a Direção da Creche/Pré-Escola Oeste, com objetivo de continuar a gestão participativa junto à comunidade. Agora estava bem mais perto das equipes de oito horas (limpeza, cozinha, zeladoria, secretária, enfermagem) e tentando compreender os procedimentos burocráticos na Universidade de São Paulo.

Considerando que o trabalho na Creche Oeste me levou de volta à academia, continuava acreditando em uma Educação Infantil carregada de significado. Dentre os vários projetos desenvolvidos na Creche/Pré Escola Oeste, resolvi investigar a relação da Oficina de Informação com a proposta pedagógica, pois acreditava na existência de algo que necessitava ser compreendido por diversos segmentos da sociedade, inclusive na própria Instituição: políticas públicas, gestores e coordenadores de Educação Infantil, educadores de infância, pais e crianças.

Assim, a possibilidade de acompanhar a Oficina de Informação, desde sua implantação na Creche/Pré Escola Oeste, pela equipe do PROESI, permitiu-me sistematizar questões, na trajetória de dez anos de existência, o que possivelmente contribuirá para a compreensão da importância de dispositivos de informação em ambientes de Educação Infantil. 


\section{Justificativa}

No ano de 1993, o Professor Dr. Edmir Perrotti, do Departamento de Biblioteconomia e Documentação da Escola de Comunicações e Artes da USP foi procurado por Pedra Margarete Siqueira, que era funcionária da Creche/Pré Escola Central da USP, e aluna do curso de Biblioteconomia, com a intenção de solicitar algum tipo de parceria para o trabalho com a informação, nas Creches da USP.

O Professor propôs à diretora da Divisão de Creches da COSEAS/USP, lara Mattos, um projeto piloto de serviço de biblioteca para a primeira infância. Foi estabelecida, então, a parceria entre o PROESI - Programa Serviços de Informação em Educação, coordenado pelo Professor Perrotti e a Divisão de Creches. Pela primeira vez, na história das Creches da USP, configurou-se esse tipo de vínculo entre pesquisa e serviço, destinado a desenvolver novos conceitos e novas configurações de dispositivos informacionais. A Creche, geralmente, utilizada pelos pesquisadores como campo de pesquisa, seria agora parceira de reflexão, diferença fundamental desse projeto que estava se constituindo. Instituiuse não apenas um novo serviço de biblioteca, mas um novo modo de produção de conhecimento para profissionais de Creches e pesquisadores.

Dentre as quatro Creches pertencentes à COSEAS, a Creche/Pré Escola Oeste, localizada no campus da Cidade Universitária de São Paulo foi a escolhida para a implantação do projeto, pela diretora da Divisão de Creches. Dois foram os motivos: O primeiro, porque na capital de São Paulo, a Creche/Pré Escola Oeste era a única que possuía um espaço destinado à biblioteca e, o segundo, porque ela precisava de um projeto que a diferenciasse das demais e motivasse o grupo, em momentos difíceis. 
No ano de 1994, portanto, foi implantado um projeto piloto, elaborado pela equipe do PROESI, ouvida a equipe da Creche e intitulado "Oficina de Informação". Nesse mesmo ano, consta no Relatório de Atividades da Divisão de Creches ${ }^{1}$ que a Oficina de Informação terá, entre outras, as seguintes características:

- espaço de produção e recepção de informação e cultura pela criança;

- espaço de construção e experimentação de novos instrumentos informacionais em educação infantil;

- espaço de encontro entre criadores de cultura em geral e crianças;

- espaço de apoio a educadores;

- espaço de difusão de conhecimentos científicos e tecnológicos, visando ao desenvolvimento do espírito científico na criança;

- espaço de difusão de conhecimentos artísticos, visando ao desenvolvimento da sensibilidade estética e da imaginação da criança;

- espaço de registro e difusão da memória cultural da comunidade a que serve.

Vislumbrava-se um novo paradigma de ambiente informacional, que buscava estabelecer relações entre os sujeitos, a informação e a cultura no contexto institucional. O projeto demandou transformações na Creche Pré/Escola Oeste, entre elas, a reorganização do espaço, propiciando um ambiente em que os sujeitos pudessem criar e recriar cultura nas várias linguagens expressivas.

Acompanhei este projeto piloto da Oficina de Informação, desde a sua implantação e, depois de 8 anos, nasceu a vontade e a necessidade de sistematizar questões que foram sendo tecidas a várias mãos.

A propósito, vale relatar um dos diversos episódios ilustrativos que me moveu a refletir sobre aspectos da Oficina de Informação e da parceria entre pesquisadores da Ciência da Informação e da Educação Infantil. A Creche/Pré Escola Oeste recebe visitas para conhecer os espaços e a proposta pedagógica, principalmente de estudantes e profissionais relacionados à Educação Infantil. Dentre as várias visitas, uma educadora, ao contemplar o espaço da Oficina de Informação,

1 Relatório de atividades é um documento elaborado pelas creches para a Divisão de Creches, que registra e analisa o que foi realizado no ano. 
afirmou: "Na educação infantil esse tipo de espaço é um verdadeiro luxo, diante da realidade existente".

A afirmação me instigou. De que luxo se tratava? Daquele ostentado, destinado a causar impacto e impressionar públicos que só conhecem penúrias? O luxo como forma de poder, manifestação de força, discriminação? Ou seria outro luxo? Um luxo de fineza de espírito, de cuidado com a educação das crianças pequenas, o luxo da poesia, da imaginação, da beleza e do respeito à infância? Acredito, não poderia a educadora estar se referindo ao luxo material, já que a "Oficina" não ostenta recursos excepcionais. Quanto aos outros tipos, seria efetivamente luxo? Ou necessidade dos novos tempos.

Há uma nova realidade cultural atingindo o fazer educativo, que necessita ser definida e compreendida em sua extensão completa, incluindo a Educação Infantil. Por isso, a história da implantação da Oficina de Informação na Creche/Pré Escola Oeste e suas relações com contextos sociais e culturais poderão contribuir para a compreensão desse dispositivo de mediação na construção de conhecimento, em um mundo cada vez mais repleto de informação e com diversos recursos tecnológicos.

Assim, a oportunidade de acompanhar a implantação da Oficina Informação, a percepção de que uma ocorrência educacional nova e relevante se apresentava, levaram-me ao interesse em documentar e refletir sobre o papel desse dispositivo no processo educativo da Creche Pré/Escola Oeste, bem como na Educação Infantil em geral. 


\section{Objetivos do trabalho}

\section{Objetivo geral}

A partir de análise de aspectos da implantação e desenvolvimento da Oficina de Informação na Creche/Pré-Escola Oeste COSEAS/USP, sistematizar referências conceituais e metodológicas que possam contribuir para a definição desse dispositivo nos processos da Educação Infantil.

\section{Objetivos específicos}

- Refletir sobre o significado educacional, social e cultural da construção da Oficina de Informação na Creche/Pré Escola Oeste;

- Identificar e analisar a apropriação dessa proposta pelas crianças, pais e funcionários;

- Refletir sobre o papel da Oficina de Informação como elo entre grupos de diferentes origens socioculturais;

- Fornecer elementos que possam servir de inspiração a outras Instituições de Educação Infantil. 


\section{Percurso Metodológico}

Realizar uma pesquisa acadêmica, tendo como campo de estudo o cotidiano de uma instituição de Educação Infantil, requer alguns esforços. Como aponta Azanha:

no fundo, o que queremos frisar é que o estudo do cotidiano só será interessante se for possível partir dele para um esforço de construção de uma ciência do homem. Sem essa possibilidade, o estudo do cotidiano não superará o nível do registro de trivialidade (1992, p.72).

Para não correr o risco dos registros triviais, escolhi percursos próprios da pesquisa etnográfica, que considera a importância de resgatar aspectos da história particular da Instituição e suas relações com contextos sociais e culturais. Assim, nossa abordagem do cotidiano escolar conceberá o "presente" na perspectiva de (SATO E SOUZA, 2001)

isto é, um presente em que se reconheçam os vestígios e as contradições de múltiplos processos de construção histórica e não um presente que suponha a coerência de um sistema social ou cultural acabado. Para conseguir isto, é necessário integrar a informação histórico local (documento e oral) e geral com a análise etnográfica (Apud Charlot 1992;p.73).

Tendo como principal objetivo analisar a relação entre Educação e Informação na Educação Infantil e o significado do dispositivo de informação na apropriação de conhecimento, busquei a Oficina de Informação inserida Creche/Pré Escola Oeste para coletar os dados necessários para pesquisa.

Para iniciar a primeira parte da coleta de dados foi necessário contextualizar o espaço em que a Oficina de Informação está inserida, a Creche/Pré Escola Oeste. Para relatar a proposta pedagógica busquei um material intitulado: "Caderno de 
Apresentação" em que a equipe de coordenação expõe as elaborações iniciais que apresentam a Creche Pré/Escola Oeste para as famílias.

Em seguida, recorri à minha memória e aos registros pessoais em cadernos de reuniões sobre o processo da Oficina de Informação. Também foi realizado levantamento da documentação que a Creche/Pré Escola Oeste possui sobre essa história, bem como de Relatórios Anuais da Divisão de Creches e Creche/Pré Escola Oeste e boletins produzidos pelas bolsistas do PROESI. Esse último material marca o investimento da equipe do PROESI em integrar a Oficina de Informação na proposta pedagógica, possibilitando que todos os segmentos da Creche (crianças, educadores, pais, funcionários, pesquisadores, bolsistas) tivessem vez e voz na apropriação da Oficina de Informação, na medida em que estavam representados no boletim.

$\mathrm{Na}$ segunda parte da coleta de dados, busquei depoimentos de pessoas (adolescentes, pais, pesquisadores, educadores e funcionários de outros segmentos da Creche) que contribuíram para a implantação da Oficina de Informação, bem como de outras que participaram do projeto até os dias de hoje. Além disso, entrei em contato com educadores, pesquisadores, pais e adolescentes que não faziam mais parte da convivência diária na Creche, de diversas formas: por telefone, e-mail e pessoalmente.

Em uma das formações continuadas realizadas pela Creche/Pré Escola Oeste, abri a possibilidade de obter depoimentos escritos por aqueles que estivessem interessados em fazê-lo, participando do meu processo de pesquisa e coleta de dados.

Consegui um conjunto de 24 depoimentos: adolescentes 2, pais 4, pesquisadores do PROESI 6, funcionário da área de limpeza 1, funcionária da cozinha 1 , educadores 8, profissionais da equipe de coordenação 2. Destes 24 depoimentos, 20 chegaram via e-mail, 4 foram entregues em mãos. 
Esses depoimentos foram analisados junto com o percurso do projeto, ao longo dos 10 anos de sua existência na Creche/Pré Escola Oeste. Nesse corpus do trabalho, a função dos depoimentos não é reconstruir a história da Oficina de Informação, pois a memória, como diz o dito popular, falha. Podemos observar essa ocorrência em um dos depoimentos, em que a mesma pessoa recupera momentos vividos de uma forma e escreve em um documento, de outra. Se tivéssemos optado por esse caminho historiográfico, a pesquisa deveria ter um tratamento investigativo e tomaria outros rumos.

A opção de dialogar com os depoimentos não tem a intenção de buscar verdades, mentiras, coerências ou incoerências sobre o processo de implantação da Oficina de Informação na Creche/Pré Escola Oeste, pois são registros de memórias: "O que se pode dizer, e que é meio óbvio, é que ela (memória) pode produzir ao mesmo tempo verdades e mentiras" (CAMARGO, 1994:83). Mas não é isso que nos interessa nesse trabalho.

Nessa dissertação, a análise dos depoimentos dos funcionários e, principalmente, das crianças tem o intuito de buscar o significado do dispositivo de informação no processo educativo, e não recuperar, passo a passo, a história da produção da Oficina, sua implantação. O objetivo é situar o sentido do dispositivo nos processos da Educação Infantil.

Não posso deixar de registrar o contexto no qual recebi o primeiro depoimento. Poucos dias após a reunião de formação continuada em que convidei a todos para escrever um depoimento, eu estava sentada defronte ao computador, quando uma das funcionárias da limpeza, Elenilza, tirou do seu bolso um papel dobradinho, escrito à mão. Em poucas palavras, a funcionária conseguiu traduzir o significado da Oficina de Informação para a Creche e para formação dos seus filhos que, por um período de suas vidas, freqüentaram o ambiente. A partir desse dia, compartilhei quase todos os depoimentos com a Elenilza, lendo-os junto com ela. 
Não pudemos conter as lágrimas de alegria e saudades, das pessoas que, um dia, fizeram parte da nossa história. Ao mesmo tempo, percebemos o quanto a experiência na Creche, em particular na Oficina de Informação, marcou essas pessoas. Nascia em nós uma grande esperança: que todas pudessem multiplicar essas vivências e contribuir para a construção de uma educação sensível e de melhor qualidade, conectada com a vida na sua totalidade. Nos depoimentos e em contatos informais, foi possível vislumbrar esse movimento nos diferentes locais onde, atualmente, essas pessoas estão trabalhando.

\section{Estrutura do trabalho}

Este trabalho está organizado em 5 partes, apresentadas a seguir, com o conteúdo desenvolvido.

Parte I - quadro teórico relativo ao significado de dispositivos de informação no mundo contemporâneo, em espaços de Educação Infantil;

Parte II - o contexto e discrição do objeto de pesquisa;

Parte III - diálogo com os depoimentos;

Parte IV - Conclusões;

Parte $\mathrm{V}$ - Bibliografia utilizada e referência bibliográfica. 
PARTE I 


\title{
1 - Informação, Educação, Cultura e Infância: possíveis relações
}

\author{
A educação do futuro exige um esforço \\ transdisciplinar que seja capaz de rejuntar \\ ciências e humanidades e romper com a \\ oposição entre natureza e cultura.
}

Edgard de Assis Carvalho

\section{1 - Dispositivos de Informação}

O avanço tecnológico e questões ligadas à informação (seu volume, o modo de produção, circulação e recepção) colocam em xeque as relações tradicionais entre informação e educação. Além disso, se no passado a comunicação face a face era privilegiada nas relações sociais, hoje, é cada vez mais mediada por "dispositivos tecno-semiopragmáticos ${ }^{2 "}$ (TSP), de natureza complexa, que possibilitam ao homem contemporâneo ultrapassar barreiras de tempo e espaço, permitindo novas experiências e interações com o mundo. Por conseguinte, vivemos, hoje, uma nova realidade cultural com o surgimento de uma ocorrência definida por Lévy como ciberespaço. Segundo ele,

ciberespaço é o novo meio de comunicação que surge da interconexão mundial dos computadores. O termo especifica não apenas a infra-estrutura material da comunicação digital, mas também o universo oceânico de informações que ela abriga, assim

\footnotetext{
${ }^{2}$ De acordo com Peraya, a definição de dispositivos tecno-semiopragmáticos seria "um conjunto de interações promovidas por toda mídia, toda máquina de comunicar, toda tecnologia da informação e da comunicação entre os universos técnico, semiótico e ainda social ou relacional". (2002, p.30).
} 
como os seres humanos que navegam e alimentam esse universo (1999, p.17).

Tal definição leva-nos a inferir que o ciberespaço não pode ser limitado ao mero espaço tecnológico de transmissão de conhecimento e busca de informação, na qual o sujeito se posiciona de forma passiva, mas abrange uma nova forma de liberdade de comunicação e expressão, a "Cibercultura" (LÉVY,1999). A oportunidade de acessar e dialogar com diversos tipos de textos e imagens no mundo inteiro, sem passar pelo crivo de especialistas como críticos ou editores, demonstra uma nova possibilidade de liberdade de expressão e de democratização das informações. Além disso, essa nova forma de conceber a informação gera, por exemplo, outras possibilidades de formação, como a autoformação, que muitas vezes está à margem das instituições educativas. Em nossa época, portanto, há possibilidade de escolha para formas diferenciadas de formação, independentemente da escola.

Navegar num oceano repleto de informação requer, contudo, capacidades, sociabilidades, competências e criticidade dos sujeitos envolvidos no processo, pois muitas vezes não se sabe nem atuar nos dispositivos, nem avaliar a qualidade das fontes e dos materiais utilizados.

Novas relações entre informação e educação decorrem, assim, dessa situação apontada. Esta implica em considerar novas formas de relações pedagógicas possíveis no ato de ensino-aprendizagem. Se antes essas comunicações eram somente realizadas face a face, agora, com o avanço tecnológico há novas possibilidades, como por exemplo, a comunicação midiatizada ${ }^{3}$.

Quando entramos em algumas Escolas ou mesmo Universidades podemos constatar que, no ato de ensinar, o professor, muitas vezes, utiliza-se da

\footnotetext{
${ }^{3}$ Entende-se por comunicação midiatizada a que se apóia em artefatos tecnológicos. De acordo com Peraya, as mídias pedagógicas dizem respeito "às formas de comunicação educativa, sistemas de representação particulares ou, ainda, sistemas semiocognitivos organizados em gêneros de texto e em tipos de discursos específicos" (2002, p.27).
} 
exposição oral e de recursos como retro-projetor, slides, filmes, etc. para dialogar com o grupo. Assim, possibilita uma composição de comunicação alternada, ora utilizando a oralidade, ora a mídia, com a possibilidade de utilização dos artefatos mais simples aos mais sofisticados: impressos, fita cassete, televisão, software e internet.

Deste modo, o desenvolvimento dos dispositivos técnicos, possibilitaram, por exemplo, a formação à distância (inclusive a autoformação) e a ocorrência de situações novas e específicas na comunicação pedagógica. Essa verdadeira revolução marca um momento especial da história da Educação. Segundo Peraya, presenciamos "dissociação dos atos de ensino e de aprendizagem, a ruptura da simultaneidade de presença dos atores da comunicação pedagógica" (2002, p.27).

Fruto dessas transformações, temos o exemplo do Programa de Formação Universitária da Universidade de São Paulo PEC/USP, que vem desenvolvendo propostas para os professores da rede Estadual e Municipal de São Paulo. Por meio dessa nova relação entre Educação e Informação, um número significativo de professores está tendo a oportunidade de freqüentar o curso superior. Muitos desses educadores, ao dialogarem com os textos propostos pela bibliografia básica do PEC, com os professores que realizam as vídeoconferências, com as tutoras $^{4}$ que acompanham o grupo diariamente e com seus pares, puderam transformar suas práticas, na busca de uma educação de qualidade para as crianças da rede pública de ensino.

Há uma nova realidade cultural afetando o fazer educativo e que necessita ser definida e compreendida em sua extensão completa, levando-nos a inferir que o processo ensino-aprendizagem, principalmente nas escolas, deve tomar outros caminhos. A forma de conceber a relação com o conhecimento, somente centrada no educador, torna-se uma verdadeira contradição, num mundo repleto de informação e equipamentos tecnológicos. Os sujeitos, hoje, têm cada vez mais a

\footnotetext{
${ }^{4}$ Nome atribuído ao profissional que acompanha cada grupo de educadores .
} 
possibilidade de buscar formação e informação nos diversos dispositivos bem como são por eles afetados, desde os mais antigos como livros, jornais, até os mais contemporâneos, como a rede internet, a Web.

\section{2 - Oficina de Informação: mediação e apropriação cultural}

Como afirmamos anteriormente, as constantes mudanças da chamada "Sociedade da Informação" trouxeram possibilidades novas para o sujeito que vive na contemporaneidade. Estas vão, desde a possibilidade de acessar diversas informações, até a liberdade de difundi-las em escala universal, via Web. Esse fato é inegável, mesmo sendo preciso considerar que nem todos os cidadãos têm condições para obter as informações, utilizando dispositivos de última geração, seja pelo custo dos equipamentos, seja por não possuírem conhecimento sobre seu modo de utilização, ou falta de acesso a espaços públicos prestadores de tais serviços.

Como o acesso à informação não significa, obrigatoriamente, a apropriação de informação, um dos caminhos possíveis para incluir, efetivamente, os cidadãos na cultura da contemporaneidade é a instituição educativa, adotando tais práticas que garantam a possibilidade de todos os segmentos das instituições (crianças, pais, educadores e funcionários) produzirem e participarem da cultura e não, apenas, consumi-la. Para tal, segundo Perrotti,

novas abordagens teórico-metodológicas são necessárias para a compreensão e o enfrentamento das complexas inter-relações entre informação e educação nos tempos presentes. Um campo epistemológico se vislumbra, de natureza interdisciplinar infoeducação (2004, p.1).

Visando essas novas conexões entre informação e educação, o espaço da biblioteca escolar pode funcionar como dispositivo de mediação nas instituições 
educativas, buscando não só acesso, mas apropriação dos recursos e conteúdos diversos, bem como das competências necessárias para tanto.

Para isso, há portanto necessidade de uma nova concepção de serviço de informação e cultura, capaz de atuar na mudança das relações atuais existentes entre biblioteca, sociedade e editoras no Brasil (PERROTTI,1999).

As bibliotecas escolares, muitas vezes, trazem resquícios de concepções das primeiras bibliotecas constituídas no mundo, que não condizem com as realidades contemporâneas. Considerando as lógicas da Antigüidade e da Idade Média, a Biblioteca, assim como a apropriação da leitura e da escrita, restringiam-se somente a alguns segmentos da sociedade, como o poder público, religioso e técnico. Tais bibliotecas traduzem um paradigma de conservação cultural e não de circulação e apropriação. Segundo Amaro (1998, p. 23) "as linguagens constróem representações concretas e simbólicas do silêncio e da escuridão, da reserva do saber que deve se manter intacto, a salvo de todos; de um lugar onde se depositam livros para não se ler e para se preservar".

As transformações no final do século XVIII foram marcadas pela Revolução Industrial e Revolução Francesa, por necessidades de diversas ordens: política, econômica e social. Em 1450, a invenção da imprensa por Gutenberg proporcionou a produção de livros em larga escala, gerando um mercado livreiro e um crescente número de bibliotecas particulares. Também na Europa, em meados de 1500, de acordo com Amaro (1998, p.25), surgem "as bibliotecas com características administrativas, organizacionais e funcionais semelhantes à grande parte das bibliotecas que temos hoje. "Essas transformações propiciaram uma nova forma de conceber as instituições bibliotecárias. Se na Idade Média as bibliotecas eram espaços de conservação, nesse período, paulatinamente, passam a ser concebidas como espaços de difusão cultural. Essa concepção prevalece durante toda a época moderna, de tal modo que, nas escolas de Ensino Fundamental, as bibliotecas, quando existem, apresentam freqüentemente essa 
concepção de difusão que corresponde aos ideais iluministas de democratização do conhecimento e da cultura.

O problema de tal concepção está, contudo, no fato de que o público das bibliotecas é visto como mero receptor dos produtos, tanto culturais como informacionais. Desse modo, de instituições de conservação, as bibliotecas modernas passaram a instituições de difusão cultural, concepção que pretenderia estender às massas a cultura das elites, tomada essa como a verdadeira cultura.

As pesquisas realizadas pelo PROESI visam, assim, a construção de um novo paradigma, a "biblioteca interativa", que busca estabelecer relações entre o sujeito, a informação e a cultura, considerando o sujeito como produtor cultural (AMARO,1998). Sendo assim, as bibliotecas escolares devem constituir-se em uma das possibilidades de apropriação das informações e de diálogo com a cultura e não, simplesmente, em espaço de acesso às informações. Enquanto espaço de apropriação cultural, a biblioteca interativa ultrapassa o simples acesso, a simples difusão e reconhece a atividade cognitiva e os repertórios dos atores como condição da participação no conhecimento e na cultura.

\section{3 - Novas relações entre Informação e Educação Infantil}

Para refletirmos a respeito das relações entre as pesquisas do PROESI e os processos de Educação Infantil, é necessário compreender como transcorreu o percurso de constituição do atendimento à criança pequena.

Primeiramente, este atendimento veio atender a uma exigência criada pela inserção, cada vez maior, das mulheres no mercado de trabalho, seja pela sua emancipação social ou pela necessidade de aumentar a renda familiar, diferentemente do que ocorria há trinta ou quarenta anos atrás. Nesse passado, elas permaneciam em casa, responsáveis pelos afazeres domésticos e educação 
dos filhos. Caso a mãe tivesse um vínculo empregatício, os filhos ficavam sob os cuidados das avós, empregados ou vizinhas. Nesse período, as crianças entravam na instituição educativa com 7 anos (idade oficial para escolaridade obrigatória).

As transformações sociais criaram novas demandas e a sociedade brasileira avançou no que diz respeito aos dispositivos legais que buscam garantir os direitos das crianças. Dentre os vários documentos, destacamos a Constituição Federal promulgada em 1988 e o Estatuto da Criança e do Adolescente, conhecido como ECA. O primeiro dispositivo legal insere a criança no mundo dos direitos humanos:

\footnotetext{
É dever da família, da sociedade e do Estado assegurar à criança $\mathrm{e}$ ao adolescente, com absoluta prioridade, o direito à vida, à saúde, à alimentação, à educação, ao lazer, à profissionalização, à cultura, à dignidade, ao respeito, à liberdade e à convivência familiar e comunitária, além de colocá-los a salvo de toda forma de negligência, discriminação, exploração, violência, crueldade e opressão (artigo 227).
}

O ECA, aprovado em 1990, reitera a criança como sujeito de direitos. Direito ao afeto, direito de brincar, direito de querer, direito de não querer, direito de não conhecer, direito de sonhar e de opinar (LEITE FILHO, 2001). Se, antes, a categoria da Infância era vista como responsabilidade única da família, após esses dispositivos legais os cuidados das crianças passam a ser compartilhados com o Estado e com os diversos segmentos da sociedade. Esse reconhecimento das crianças como sujeitos de direitos e membros plenos da sociedade promoveu a formulação de uma nova concepção de infância. Agora, é sabido que, independentemente das famílias e adultos, as crianças têm desejos, vontades, necessidades e interesses.

Se do ponto de vista legal, constatamos que os direitos das crianças estão assegurados, reportagens, documentários, estudos e pesquisas (ARROYO, 1999, PINTO e SARMENTO,1997) denunciam a realidade de diversas crianças que, independentemente da classe social, não têm efetivamente, o direito de desfrutar 
a infância, seja trabalhando (como vendedoras, ou braços nas colheitas), seja inseridas em instituições assistencialistas ou, até mesmo, cumprindo agendas carregadas de cursos extracurriculares. De um lado, as crianças tentam sobreviver no presente, de outro, preparam-se para um futuro longínqüo, perdendo o direito à infância.

Manifestações da sociedade civil e de órgãos governamentais foram relevantes para o reconhecimento de um atendimento específico para a faixa etária de 0 a 6 anos. Essa luta culminou na Constituição Federal de 1988, no artigo 208, inciso IV, firmando que a Educação Infantil em creches e pré-escolas é um dever do Estado e um direito da criança. Legitimando essas mudanças, a lei de Diretrizes e Bases da Educação Nacional, Lei no 9.394, promulgada em dezembro de 1996, estabelece um elo entre o cuidado e a educação para crianças entre zero a seis anos. No intuito de somar esforços ao atendimento de qualidade à criança pequena, as Diretrizes Curriculares Nacionais para a Educação Infantil de 1998, define que as Propostas Pedagógicas devem promover a integração entre os aspectos físicos, emocionais, afetivos, cognitivos/lingüísticos e sociais. Dessa forma, compreende-se as meninas e os meninos como sujeitos únicos, completos e indivisíveis. Assim, do ponto de vista legal, tivemos um avanço significativo para o atendimento à criança pequena. Porém, no que diz respeito à quantidade de vagas e à qualidade do atendimento, ainda existe muito por fazer.

Focando a qualidade do atendimento encontramos, em muitas instituições de educação infantil, propostas pedagógicas que revelam certo desrespeito ao potencial humano e possibilidades de expressão nesta faixa de idade, pois proporcionam rotinas rígidas, com objetivo de preparar as crianças para o ensino fundamental, o que demonstra desconhecimento do desenvolvimento infantil ou, até mesmo, atuam de forma compensatória. Segundo Oliveira,

sob o nome de "educação compensatória", foram sendo elaboradas propostas de trabalho para as creches e pré-escolas que atendiam a população de baixa renda. Tais propostas visavam 
à estimulação precoce e ao preparo para alfabetização, mantendo, no entanto, as práticas educativas geradas por uma visão assistencialista de educação e do ensino (2002, p.109).

Tais concepções podem criar rotinas estressantes, cansativas, repetitivas e sem significado, pois não consideram o tempo biológico e nem mesmo o contexto histórico em que as crianças vivem. Pesquisas revelam que, muitas vezes, crianças menores de 6 anos são obrigadas a manter certas posturas corporais e situações de concentração por muito tempo, a fim de realizarem as atividades propostas. (GALVÃO,1996). Essa exigência demonstra um desconhecimento sobre a capacidade de controle do sujeito sobre suas próprias ações. Segundo Wallon "essa capacidade está ligada ao amadurecimento dos centros de inibição e discriminação situados no córtex cerebral, que se dá por volta dos seis, sete anos" (apud GALVÃO 1995, p.78). Desta forma, as crianças menores de 7 anos têm pouco controle sobre suas ações e acabam manifestando dificuldades de permanecerem, por muito tempo, na mesma posição e concentradas, gerando inquietações que, muitas vezes, são interpretadas como indisciplina.

Em oposição a essa realidade, o dia-a-dia nos ambientes de Educação Infantil deve proporcionar rotinas dinâmicas, mutáveis de acordo com as condições, necessidades e interesses das crianças; assim, serão seus movimentos, gestos e expressões que darão "pistas" para possíveis alterações.

Segundo O Referencial Curricular Nacional para Educação Infantil (BRASII/MEC/SEF, 1998, p.73, v. I), a rotina deve ser facilitadora, ou seja, deve proporcionar dinamização da aprendizagem. Essa rotina necessita ser clara para todos pois, ao mesmo tempo em que propicia segurança às crianças, também garante uma compreensão sobre o tempo e espaço na instituição educativa. A organização didática do tempo, muitas vezes, traz marcas de concepções elaboradas por um momento histórico que não condiz com uma Educação Infantil pautada em qualidade e sensibilidade. 
Tonucci (p. 127, 1997) critica certas rotinas de período integral, expressando sua indignação da seguinte forma:

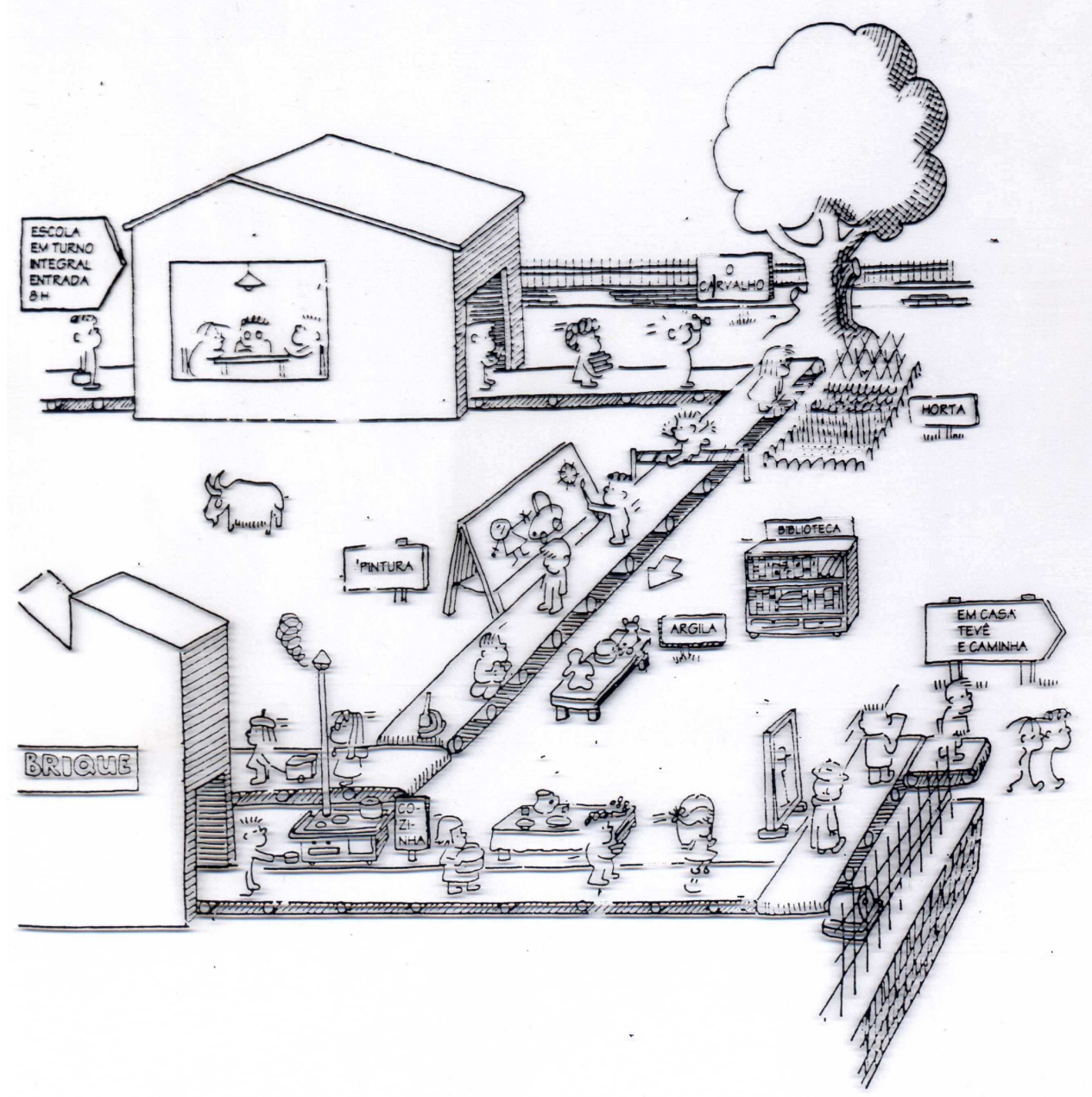

Figura 1 - [1974] Os perigos de um turno integral pleno na escola

Essa representação de rotina, inspirada no funcionamento de uma fábrica, demonstra algo rígido, inflexível, com movimentos repetitivos, que pouco contempla a expressão da infância, nos ambientes educacionais. Acredita-se que o tempo didático da rotina de período integral deva ser organizado de acordo com o ritmo do grupo e de cada membro que o forma, garantidos os cuidados, as brincadeiras e atividades dirigidas, assim como a livre expressão e o respeito e valorização dos momentos de ociosidade; caso as crianças sintam vontade e/ou 
necessidade de estar só, sabem que têm o "direito de ir e vir", não são obrigadas a seguir o curso da "esteira ", que Tonucci denuncia em sua charge.

Além de planejar o tempo didático na Instituição de Educação Infantil, a organização do espaço é outro elemento fundamental na estruturação da rotina. De acordo com Forneiro (1998, p 229) "o tema dos espaços é uma novidade na Educação", especialmente na Educação Infantil. Ao consultar o dicionário, encontram-se algumas definições de espaço, dentre elas: "extensão limitada" e "distância linear entre duas coisas, objetos etc."

Tais definições remetem-nos à idéia de que o espaço é algo mais do que um local físico, ocupado por objetos. Compreende-se o espaço, tanto para crianças como para os adultos, como algo que transcende uma delimitação física, um espaço de vida com tudo aquilo que nele tem participação: a sua extensão, os móveis, as decorações, os objetos, as cores, os cheiros, os sons, as pessoas, as relações, as memórias (GOZZI; SEKKEL, 2003).

Discutindo sobre os espaços na Educação Infantil, Forneiro faz uma distinção entre os termos espaço e ambiente, embora se reconheça existir um interrelacionamento entre eles:

O termo espaço refere-se ao espaço físico, ou seja, aos locais para a atividade caracterizados pelos objetos, pelos materiais didáticos, pelo mobiliário e pela decoração. Já, o termo ambiente refere-se ao conjunto do espaço físico e às relações que se estabelecem no mesmo (os, afetos, as relações interpessoais entre as crianças, entre crianças e adultos, entre crianças e sociedade em seu conjunto) (1988, p 232e 233)

Do ponto de vista educacional, deve-se compreender o ambiente como um "conteúdo" essencial na formação das crianças e adultos inseridos na instituição. Esse ambiente deve ser planejado pelos educadores, que se transforma em seu parceiro, propiciando interação entre as crianças de idades próximas e diferentes, 
convidando para utilização de materiais e brinquedos, dialogando com a cultura nos vários dispositivos de informação e formação, criando situações de participação e de cooperação entre os participantes do grupo. Os ambientes devem ser planejados à luz de alguns princípios tais como: estruturação e polivalência, autonomia, segurança e estética (FORNEIRO, 1998).

Em relação à estruturação, deve-se considerar as condições físicas do prédio, suas possibilidades de uso, tanto dentro da instituição, quanto no âmbito da própria cidade. O desafio é utilizar outros ambientes da Instituição Educativa, além da sala de atividade, proporcionando novas experiências e sensações e ampliando-as, com a visitação a espaços públicos como teatros, cinemas, museus, centros culturais, galerias, praças, bibliotecas, etc. Além disso, acrescenta-se a possibilidade de buscar informações virtualmente, visando ampliar a leitura de mundo por parte das crianças.

Quanto à autonomia, aspecto fundamental para o desenvolvimento do sujeito que vive numa sociedade democrática, deve ser construída desde a Educação Infantil. Kamii (1989, p. 103) faz uma distinção entre autonomia e heteronomia, definindoas: "Autonomia significa ser governado por si próprio. É o contrário de heteronomia, que significa ser governado por outrem". Os bebês humanos nascem extremamente dependentes dos adultos, mas na relação com o meio vão se tornando independentes e autônomos. Para tal, os ambientes devem ser transformados de acordo com o desenvolvimento e possibilidades das crianças, promovendo desafios e escolhas.

A segurança também é fundamental nos cuidados aos ambientes de Educação Infantil, buscando garantir na estrutura do prédio e nos materiais, a salubridade e higienização. É importante verificar se os móveis estão estáveis e não apresentam arestas, assim como outros materiais que circulam ou fazem parte do ambiente. Dessa forma, alguns acidentes poderão ser evitados. 
Um outro princípio a ser considerado é a presença da sensibilidade estética, que deve permear todos os ambientes da Instituição Educativa. O ambiente precisa estar limpo, arejado, colorido, agradável e belo, decorado com as expressões artísticas das próprias crianças e reproduções de artistas pesquisados nos projetos; os materiais devem ser apresentados de forma cuidadosa e atraente. Compreende-se que educar para sensibilidade estética possibilita às crianças o desenvolvimento da dimensão estética na vida (GOZZI; SEKKEL, 2003).

Nessa perspectiva, busca-se um ambiente em que as crianças possam sonhar, imaginar e jogar com a realidade, ambientes em que elas possam se expressar nas várias linguagens, ambientes em que elas aprendam a se apropriar, ambientes em que se sintam acolhidas e seguras, em que expressem a cultura da infância e do mundo contemporâneo.

\begin{abstract}
A casa é o nosso canto do mundo. Ela é, como se diz amiúde, o nosso primeiro universo. É um verdadeiro cosmos. Um cosmos em toda a acepção do termo. (...) Qual o benefício mais precioso da casa, diríamos: a casa abriga o devaneio, a casa protege o sonho, a casa permite sonhar em paz. Só os pensamentos e as experiências sancionam os valores humanos. Ao devaneio pertencem valores que marcam o homem em sua profundidade. $O$ devaneio tem mesmo um privilégio de autovalorização. Ele usufrui diretamente de seu ser. Então, os lugares onde se viveu o devaneio reconstituem-se por si mesmos num novo devaneio. É exatamente porque as lembranças das antigas moradas são revividas como devaneios que as moradas do passado são imperecíveis dentro de nós (BACHELARD, 2000, p.24 e 26).
\end{abstract}

Essa afirmação do autor nos faz pensar que a escola de Educação Infantil necessita consolidar-se como mais um ambiente significativo para as crianças pequenas, já que elas passam boa parte do tempo nas instituições. Nesse ambiente, o saber cuidar, principalmente para os pequenos, deve ter destaque nas relações. Segundo Boff (2002, p 32), "cuidar é mais que um ato; é uma atitude. Portanto, abrange mais que um momento de atenção, de zelo e de desvelo. Representa uma atitude de ocupação, preocupação, de responsabilização e de envolvimento afetivo com o outro." 
Essa atitude de cuidar das crianças, em instituições educativas, deve também permear as relações com as famílias, educadores, funcionários, repercutindo nas questões sociais e ecológicas do mundo. Desenvolver essa atitude de cuidar pressupõe que o indivíduo se preocupe com o outro, com suas necessidades, dificuldades, sofrimentos, com suas buscas, conquistas, enfim, com sua vida.

Um ambiente institucional que cuida das relações das crianças pequenas com seus pares, com os adultos, com 0 ato de conhecer, necessita cuidar dos protagonistas que atuam diretamente com elas - os educadores e as educadoras. Hoje, em algumas instituições educativas, os educadores e as educadoras, apesar de estarem juntos, vivem situações de isolamento quando necessitam expor seus medos, angústias, inquietações, dificuldades e até mesmo trocar suas experiências, para servir de inspiração a outros trabalhos. O ambiente da instituição deve proporcionar aos protagonistas, espaços em que possam se expressar, ser ouvidos, demonstrando assim, verdadeiramente, a atitude de cuidar para com todos.

No âmbito de tais questões inserem-se as preocupações com novos ambientes de informação e cultura na Educação Infantil, projeto levado a cabo pela Oficina de Informação. A cultura contemporânea exige novos espaços e ambientes nas instituições de Educação Infantil possibilitadores de novas relações com 0 conhecimento e a cultura.

As pesquisas do PROESI vinham nessa direção de construção de referências teóricas e metodológicas, indispensável na criação de novos ambientes de informação e cultura nos processos educativos.

Fruto da pesquisa do PROESI e da parceria com a Divisão de Creches da COSEAS/USP, surge assim, a primeira biblioteca interativa na Educação Infantil, batizada de "Oficina de Informação", situada na Creche/Pré Escola Oeste onde se elaborou e experimentou um novo conceito de ambiente cultural para a infância, 
concebido e organizado a partir de algumas definições indicadas por Amaro (1998) :

a) espaço de produção e recepção de informações destinado a educandos e educadores da Creche;

b) espaço de produção de informação e de construção de novos instrumentos informacionais, sob forma cooperativa, envolvendo educadores, educandos, seus familiares e a comunidade em que a Creche está integrada;

c) espaço de encontro entre produtores de cultura, educando e educadores;

d) espaço aglutinador e orientador das demandas informacionais da instituição (apud PERROTTI,1996).

Essas definições elaboradas pela equipe do PROESI, demonstram a importância de incluir, não só as crianças, mas todos os segmentos da Instituição Educativa nos ambientes informacionais, postura diferente da assumida pelo Referencial Curricular para Educação Infantil - RCNEI, que tem grande preocupação em incluir, nos espaços de leituras, somente as crianças ${ }^{5}$.

\footnotetext{
${ }^{5}$ Ver a respeito no RCNI, p156. vol 3 ).
} 
PARTE II 


\section{2 - O CONTEXTO DA PESQUISA}

Cada creche e cada pré-escola tem seu próprio passado e evolução, suas próprias camadas de experiência e sua mescla peculiar de estilos e níveis culturais. Jamais houve, de nossa parte, qualquer desejo de torná-las todas iguais.

Loris Malaguzzi

\section{1 - Creches da Universidade de São Paulo: breve histórico}

A Creche/Pré-Escola Oeste mantém estreitas relações com a comunidade em que está inserida, desde a sua origem. A história das Creches na Universidade da qual é parte integrante, data de 1965, quando a comunidade começou a buscar um espaço para seus filhos.

De acordo com o Relatório de Atividades da Divisão de Creches $^{6}$, a primeira reivindicação de Creche, de que se tem registro na Universidade de São Paulo, data de 1965. Nessa ocasião, um grupo de funcionários da Reitoria, encaminhou um pedido formal ao Reitor, solicitando "um espaço para deixar seus filhos, durante a jornada de trabalho“. Não conseguiu ser atendido, mas despertou, na comunidade, principalmente entre as mulheres, a necessidade da luta por uma creche. No início dos anos 70, um abaixo assinado com cerca de 3.000 assinaturas, foi encaminhado ao Reitor, solicitando providências para a construção de um equipamento para crianças pequenas, filhas de funcionários. Esta reivindicação mostra que, nessa época, não se pensava no direito das crianças à

\footnotetext{
${ }^{6}$ O Relatório de Atividades da Divisão de Creches foi elaborado pela diretora lara Mattos
} 
educação infantil, apenas num espaço de guarda para as mães deixarem seus filhos e poderem trabalhar.

Em 1975, uma famosa e histórica passeata de bebês, em frente ao prédio da Reitoria, organizada por um grupo de mães da comunidade, culminou na implantação da $1^{\text {a }}$ creche do campus, após 10 anos de luta.

No texto intitulado "O movimento de mulheres e a abertura política no Brasil - $O$ caso da Creche", Rosemberg (1989, p.96-97) faz menção a essa passeata: "Pela primeira vez na cidade, uma manifestação pública de impacto, organizada em torno da reivindicação por creche: é o movimento de funcionários, alunos e professores da Universidade de São Paulo".

Após esse fato, a COSEAS contratou dois psicólogos para a elaboração de um projeto de instalação de uma creche dentro da Universidade. O projeto foi iniciado, mas sofre diversas interrupções, por questões de ordem interna da COSEAS e por falta de verbas. Finalmente, entre 1979/1980, o projeto foi retomado e culminou com a construção da primeira creche da COSEAS.

No segundo semestre de 1981, foi feita, pela equipe encarregada do projeto, uma pesquisa no campus de São Paulo, envolvendo todo o universo das mulheres da Universidade (docentes, servidoras e alunas), com o objetivo de levantar a demanda existente, investigar a expectativa em relação à creche e estabelecer parâmetros para os critérios de seleção, proporcionalidade de vagas entre as três categorias (funcionários, docentes e estudante), horários de funcionamento, etc.

Foram distribuídos 19.359 questionários (2820 funcionários, 15.685 alunas e 854 docentes), com um retorno de 5.583 (28,8\%) questionários válidos, concentrado na categoria das funcionárias (81\%). O resultado dessa pesquisa respaldou as principais diretrizes da equipe de planejamento, na distribuição de vagas e critérios de seleção das crianças (MATTOS,1990, p.4). 
O projeto da primeira creche (hoje denominada Creche/Pré Escola Central) foi pensado com a perspectiva de atender 250 crianças. A Creche Central começou a funcionar em julho de 1982, atendendo filhos de alunos, docentes e funcionários da Universidade.

Dessa data para cá, o serviço de creches da COSEAS foi ampliado e hoje atende a 550 crianças, distribuídas em 4 creches: em São Paulo: Creche/Pré Escola Central, Creche/Pré Escola Oeste e Creche/Pré Escola Saúde, e no campus de Ribeirão Preto, a Creche e Pré Escola Carochinha.

\section{2 - A Creche/Pré Escola Oeste}

A conquista pelo espaço da Creche/Pré Escola Oeste no campus da Universidade também se deu após diversas reivindicações dos funcionários da Prefeitura. Em abril de 1986, a COSEAS inicia o atendimento exclusivo a 25 crianças, filhos desses trabalhadores. O espaço, uma pequena "casa" ao lado da Unidade, chamada de Creche PCO (Prefeitura da Cidade Universitária). Essa casa fazia parte do protótipo de urbanização da favela São Remo, que previa construção de moradia a baixo custo e de ágil execução.

A Creche PCO era muito pequena e sem estrutura para atender a uma demanda maior. Além disso, não foi concebida para ser creche e tinha alguns problemas, como uma cozinha muito pequena, por exemplo. No ano de 1990, a Creche ganha um novo prédio composto por três segmentos: prédio administrativo com mezanino, módulo I e módulo II, para atender 110 crianças, dependentes de funcionários (85\%), docentes (5\%) e estudantes (10\%) de todas as unidades da Universidade. Nesse momento passa a se chamar "Creche Oeste". No seu terreno, foi conservada parte da pequena construção da antiga Creche, por solicitação da Faculdade de Arquitetura e Urbanismo. Esse pedido deu-se em 
função do tipo de tijolos utilizados, produzidos a partir de uma técnica chamada solo-cimento, não mais praticada. Como marca dessa história é, atualmente, utilizada como sala-ambiente para os bebês.

\section{3 - Implicações no Espaço Físico da Creche/Pré Escola Oeste}

Inaugurada a Creche/Pré Escola Oeste ${ }^{7}$, e iniciadas suas atividades, começaram a se evidenciar inadequações entre estruturas do prédio e seu uso como equipamento educativo para crianças; um exemplo foi o emprego de elementos vazados. Construída uma parede com tais materiais para evitar circulação ao redor do módulo II, ela passou a servir de escada para os meninos maiores subirem ao telhado, gerando inúmeros riscos e vigília atenta por parte dos educadores. Por isso, no ano de 1994, o muro foi derrubado. Atualmente, as crianças circulam no espaço de braços dados, olhando por trás das caixilharias, procurando insetos, escondendo-se de amigos e adultos, ou apenas deitados no gramado, como diz o ditado popular: de papo para o ar, enfim descobrindo cada pedaço do terreno, como se estivessem numa floresta secreta.

Nos corredores e refeitórios da Creche, por outro lado, se os elementos vazados também foram uma forma bastante interessante de aproveitar a luminosidade natural e propiciar um ambiente agradável, no que diz respeito ao conforto térmico, deixavam muito a desejar: extremamente frios no inverno e super quentes no verão. Nos corredores os elementos vazados eram portas de entrada para felinos e roedores. Os problemas apresentados exigiam busca de soluções. Segundo o Plano de Trabalho da Divisão de Creches de 1994 a 1997:

A solução definitiva para os problemas que os elementos vazados trazem seria a colocação de vidros, mas, em função do custo, arquitetos e engenheiros da PCO propuseram 0 plantio de

\footnotetext{
${ }^{7}$ Após a LDB a Creche Oeste passou a ser chamada de Creche/ Pré Escola Oeste, pois atende crianças de 0 a 3 anos e de 4 a 6 anos.
} 
arbustos para minimizar as dificuldades. O departamento de Zoonose desaconselhou tal medida e foi providenciado recentemente, como alternativa, a colocação de telas.

Uma outra providência foi tomada para afastar os ratos: a colocação de um aparelho similador de terremotos. Até os dias de hoje, a Creche utiliza esse aparelho Sismontron e as telas, evitando a entrada desses animais. Em relação ao desconforto térmico causado no inverno, educadores e crianças, na tentativa de resolverem o problema, passaram a preencher os elementos vazados com bolas de jornais. Se, por um lado, veda-se o frio, por outro, a técnica gera um grande acumulo de poeira, que pode ser prejudicial à saúde das crianças e adultos, principalmente para aquelas com problemas respiratórios.

No intuito de solucionar esse problema, uma arquiteta que na época tinha seu filhos na Creche, sugeriu substituir os elementos vazados por caixilho maximoar, acompanhando o projeto arquitetônico original da Creche. No ano de 1995, esses elementos vazados foram trocados por caixilho basculante, devido o baixo custo desse material. Do ponto de vista estético, esse caixilho distou do projeto original da Creche; já do ponto de vista climático, o ambiente no inverno ficou mais aquecido, porém no verão o calor continuou ardente.

O Projeto Anual da Divisão de Creches de 1994 a 1996 menciona: "O prédio é localizado numa área que, de acordo com sua inclinação, em épocas de chuvas tem suas dependências inundadas..." Esse fato produziu inúmeras infiltrações em diversos espaços da Creche: refeitório, corredores, salas de atividades e até na Oficina de Informação, causando riscos para as pessoas que circulavam nos espaços, pois o piso ficava escorregadio. O problema das infiltrações na Oficina de Informação apresentava um agravante: a água da chuva escorria pelas paredes, danificando diversos livros de literatura infantil e encharcando diversas almofadas de pano. Na tentativa de evitar as diversas perdas, as equipes, tanto da Creche como do PROESI, em todos os finais de tarde e de semana, recolhiam os livros dos expositores e afastavam caixas e materiais das paredes 
e do chão. Esse procedimento jamais poderia ser esquecido pelos adultos, se não haveria prejuízo na certa, caso chovesse.

A situação chegou a tal extremo, que o professor coordenador do projeto da Oficina de Informação, Professor Dr. Edmir Perrotti, procurou o coordenador da COSEAS, na época, Professor Dr. Hamilton Correia, solicitando providências em relação às infiltrações. Algumas soluções foram encontradas por especialistas; uma delas, talvez a mais simples, era retirar as folhas das árvores que caíam sobre o telhado com mais freqüência. Essa solução resolveu parcialmente o problema.

Após 10 anos de intensas infiltrações nos dias de chuva, um arquiteto avaliou que o problema das infiltrações nas dependências da Creche era devido ao fato de os rufos serem estreitos, não comportando a quantidade da água da chuva, escorrendo pela parede. Além disso, os rufos não estavam afixados com cola de silicone, material adequado para o local. Em janeiro de 2005, conseguimos junto à Divisão de Creches trocar e afixar os rufos adequadamente, chumbando-os na parede e, até o momento, as infiltrações foram solucionadas.

Outro problema que a Creche enfrentou refere-se às dimensões dos espaços. $O$ Plano anual revela que a Creche foi projetada para ocupar um terreno bem maior. A diminuição alterou o projeto original reduzindo em $20 \mathrm{~m}^{2}$ o espaço destinado ao berçário. Além disso, foi necessário construir um mezanino para compor todas as dependências necessárias para o funcionamento do equipamento.

Quando o módulo II começou a ser povoado pelas crianças, o grupo de adultos foi identificando diversos problemas. As paredes conservavam a cor original dos tijolos, que escurecia todas as dependências do módulo; nem mesmo a luz artificial dava conta de clarear o ambiente. As dimensões dos refeitórios não comportavam a quantidade de crianças, o que dificultava a locomoção e gerava ruídos desagradáveis. Na tentativa de propiciar um ambiente agradável, os adultos 
organizaram horários escalonados por grupos, para evitar os grandes ruídos e a possibilidade de circulação entre as mesas; mesmo assim, as dificuldades continuaram nesses momentos. Na busca de soluções, cogitou-se um outro espaço para uso como refeitório, entre o módulo I e módulo II, contudo, sua localização e exposição a ventos, poeiras, chuvas, ruídos de automóveis, impediam a utilização, principalmente, para esse fim. Atualmente, as crianças utilizam esse espaço como pátio coberto para suas diversas brincadeiras. Desde 2002, a Divisão de Creches comprou toldos para colocar nas laterais do galpão, evitando a entrada dos ventos fortes e dos pingos de chuvas transversais.

Outro grave problema, no módulo II, foi a dimensão dos espaços das salas de atividade. Segundo as regras para credenciamento e funcionamento de instituições de Educação Infantil, deliberado em maio de 1998, capitulo V, art. 15, parágrafo único diz: "Recomenda-se que a área coberta mínima para as salas de atividade das crianças seja de $1,50 \mathrm{~m}^{2}$ por crianças atendidas". A Creche atendia, em cada sala de $16 \mathrm{~m}^{2}$, cerca de 18 a 20 crianças, quantidade extremamente inadequada para algumas atividades. As educadoras, principalmente as do Pré, tentavam utilizar o espaço externo, para que as crianças pudessem fazer suas atividades, confortavelmente, levando até mesmo lousa portátil. Contudo, o barulho dos automóveis, impedia o diálogo entre crianças e adultos. Diante disso, a coordenação teve que reduzir o atendimento para 15 crianças. Mas, mesmo assim, não solucionou o problema das três salas que compõem o módulo II.

Começou uma luta para ampliação das salas e construção de um novo refeitório, que seria também utilizado para outras demandas: reunião de funcionários e pais. No final do ano de 2003, a Creche conquistou parecer favorável a suas solicitações, contando com a participação ativa da Associação de Pais e Funcionários junto à Divisão de Creches. As salas do módulo passaram a medir, aproximadamente, $32 \mathrm{~m}^{2}$ e atender 20 crianças. As paredes internas dos Módulos foram pintadas de branco, propiciando um espaço mais claro e arejado. Um 
refeitório de, aproximadamente, $45 \mathrm{~m}^{2}$ foi construído em uma parte do pátio. No momento atual registram-se problemas de acústica nesse ambiente.

No $2^{\circ}$ semestre de 2004, a Creche começa a planejar a festa dos 10 anos de Oficina de Informação, quando necessitou interditar alguns espaços, devido às telhas que estavam cedendo. Especialistas diagnosticaram que tal problema seria solucionado se as telhas fossem amarradas uma a uma. Sendo assim, a Creche cancelou o atendimento às crianças por alguns dias, na tentativa de encontrar caminhos para o atendimento. Essa atitude criou um grande mal estar na comunidade, que manifestou sua indignação de muitas formas, dentre elas, convite de reuniões com os pais no jornal do Sindicato dos Trabalhadores da USP - SINTUSP - para pensar em caminhos.

A Creche, por sua vez, foi pensando em possibilidades para atender às crianças, a partir de sugestões do grupo de funcionários, pais e a Divisão de Creches. Resolveu-se atender as crianças do G4 no refeitório do módulo I, as crianças do G5 na pequenina sala da coordenação, localizada no saguão da Creche e, o último grupo, G6, na Oficina de Informação.

Alguns materiais da Oficina de Informação como caixa de livros, televisão, som, vídeo, almofadas e uma pequena estante foram transferidos para a sala de descanso, situada ao lado do espaço. Apesar de o ambiente ser bastante pequeno, a educadora responsável conseguiu manter as características da Oficina de Informação. Desta forma, as crianças e adultos poderiam continuar desfrutando do espaço, mesmo com inúmeras limitações.

As crianças surpreenderam os adultos da Creche com tanta disponibilidade para o novo e o diferente. O acesso ao módulo I somente era possível através de um corredor entre o alambrado da Prefeitura e a cozinha, que nem todos conheciam. Os bebês estranharam inicialmente, e as crianças maiores achavam divertido, uma delas do G5 achou incrível ter uma passagem secreta na Creche. Já o G6, 
gostou muito de ocupar a Oficina de Informação e a coordenação ficava espantada de observar a quantidade de tempo que as crianças permaneciam no espaço. Afinal, a Oficina de Informação era somente deles.

Em 2005, a reforma do telhado terminou, e iniciamos o ano, atendendo as crianças nos espaços de origem. As dificuldades no cotidiano de Creche, trazidas por questões topográficas e estruturais da construção do prédio, levaram a Creche a um aprendizado: a importância de buscar soluções com todos os envolvidos (pais, funcionários, educadores, coordenação e supervisão), incluindo profissionais especialistas em área não ligada à educação, como engenheiros e arquitetos.

\section{4 - Proposta Pedagógica da Creche/Pré Escola Oeste}

\subsection{1 - Dispositivo legal}

Antes de abordar a proposta pedagógica, é fundamental registrar que o atendimento à criança pequena está garantido em vários dispositivos legais, dentre eles, na Lei de Diretrizes e Bases da Educação Nacional, Lei n`9.394/96, promulgada em dezembro de 1996 que, no capítulo II, seção II, art. 29, estabelece:

A educação infantil, primeira etapa da educação básica, tem como finalidade o desenvolvimento integral da criança até os 6 anos de idade, em seus aspectos físico, psicológico, intelectual e social, complementando a ação da família e da sociedade.

Mesmo antes dos dispositivos legais nacionais estarem vigorando, a Divisão de Creches, que administra a Creche/Pré Escola Oeste, já concebia o atendimento à criança como um direito dos pequenos ao desenvolvimento integral. 


\subsection{2 - Concepção da Creche/ Pré Escola Oeste}

A Creche/Pré Escola Oeste vem construindo sua proposta pedagógica, na relação com as crianças, educadores, funcionários e pais. Conforme documento síntese da proposta pedagógica da Creche Oeste $(2002)^{8}$, concebe-se como uma instituição educacional em que a criança tem direito à brincadeira, à atenção individual, ao afeto, ao ambiente seguro e desafiante, à higiene, à saúde e à alimentação. Procura propiciar às crianças um desenvolvimento integral nos aspectos físico, cognitivo, moral, emocional e social para que possam construir sua identidade pessoal e cultural.

Na construção da proposta pedagógica referendam-se os seguintes princípios, os quais também estão legitimados nos documentos da educação nacional: autonomia, cooperação, participação, respeito e justiça. Além desses, acrescentou-se a afetividade, que é essencial na Educação Infantil. Para traduzir esta concepção a Creche/Pré-Escola Oeste tem como objetivos:

- Construir vínculos de confiança entre as crianças, educadores, pais e os funcionários da Creche;

- promover a convivência entre crianças de diferentes idades e de diferentes níveis sócioeconômicos e ambientes culturais, e a reflexão sobre essas diferenças;

- apropriar-se de cultura e produzi-la, a partir das várias linguagens expressivas;

- Elaborar projetos de trabalho com temáticas familiares às crianças, possibilitando pesquisas diretas e com o uso de vários dispositivos de informação;

- promover o desenvolvimento da capacidade de imaginação, expressão e crítica;

- propiciar situação em que as crianças desenvolvam as linguagens expressivas: desenho, pintura, oralidade, movimento,etc;

8 Documento originalmente produzido para comunicação entre creche, pais e comunidade produzido pela coordenação a partir das práticas existentes. 
- garantir espaços em que as crianças possam escolher propostas e parceiros para desenvolver seus trabalhos e brincadeiras;

- construir regras de convivência a partir de princípios que fazem parte da dignidade humana;

- promover a formação de atitudes de respeito e preservação ao meio ambiente;

- promover a formação de prevenção da saúde, tanto individual como coletiva;

- promover a formação de bons hábitos alimentares;

- garantir a atenção e o atendimento às necessidades físicas, emocionais e sociais;

- criar condições para que as crianças possam desenvolver sua autonomia e participação na organização do seu dia-a-dia na Creche;

- criar condições para a construção de um coletivo de educadores/funcionários de forma articulada e participativa e que integre a relação com as crianças, família e comunidade;

- elaborar registros que dêem visibilidade e oportunidade de reflexão sobre todos os âmbitos do trabalho desenvolvido.

Todos esses objetivos convergem no sentido de incentivar o desenvolvimento pessoal e cultural para atuarem na e para uma sociedade democrática.

\subsection{3 - Estrutura / Funcionamento}

\section{- Quadro de pessoal}

A Creche/Pré Escola Oeste conta com 43 funcionários para o desenvolvimento de um trabalho de qualidade. Os educadores e as auxiliares de enfermagem trabalham 6 horas diárias, em grupos nos períodos da manhã e tarde, viabilizando o atendimento às crianças em período integral. Os outros funcionários têm um contrato de trabalho de 8 horas diárias. 
Quadro 1 Quadro de pessoal (número de funcionários e função) Creche

Pré/Escola Oeste:

\begin{tabular}{|c|l|}
\hline Quant. & \multicolumn{1}{|c|}{ Função } \\
\hline 02 & Aux. cozinha \\
\hline 04 & Aux. de Serv. Gerais ${ }^{9}$ \\
\hline 02 & Aux. de Enfermagem \\
\hline 01 & Aux. Administrativo (a) ${ }^{10}$ \\
\hline 01 & Cozinheiro (a) \\
\hline 01 & Diretor ( a) $^{10}$ \\
\hline 25 & Educadores (as) \\
\hline 02 & Estagiário - educador (as) ${ }^{12}$ \\
\hline 01 & Lactarista $^{12}$ \\
\hline 01 & Pedagogo (a) \\
\hline 01 & Psicólogo ( a) \\
\hline 01 & pedreiro ${ }^{13}$ \\
\hline 01 & Tec. Administrativo (a) $^{13}$ \\
\hline 01 & Tec. Nutrição \\
\hline 01 & Zelador \\
\hline 45 & Total \\
\hline
\end{tabular}

\footnotetext{
${ }^{9}$ Uma das funcionárias da limpeza está readaptada na lavanderia.

${ }^{10}$ Criou-se uma vaga de auxiliar administrativo para readaptar a cozinheira da Creche/Pré Escola Oeste.

${ }^{11}$ Creche/Pré Escola Oeste tem somente uma educadora de 8 horas que não tem grupo de crianças. Uma das tarefas desse educador é articular os dois períodos, manhã e tarde.

${ }^{12}$ As Creches da USP podem contar com pelo menos duas estagiárias estudantes de pedagogia. Essas estagiárias têm a mesma função dos educadores, porém o vínculo empregatício é diferenciado.

${ }^{13}$ Em 2002, os funcionários da manutenção da COSEAS foram alocados nas Divisões de Serviços.
} 


\section{- Razão Adulto/ Criança}

Para viabilizar o projeto pedagógico, a Divisão de Creches mantém, nas creches que administra, uma razão adulto/ criança, considerando as necessidades de cada faixa etária. Assim foi, também, na constituição da Creche/Pré Escola Oeste.

Quadro 2 - Razão educador/ criança

\begin{tabular}{|c|c|c|c|c|c|c|}
\hline \multirow{3}{*}{$\begin{array}{c}\text { Grupo / } \\
\text { Faixa-etária }\end{array}$} & \multirow{3}{*}{$\begin{array}{c}\mathrm{N}^{\circ} \mathrm{de} \\
\text { crianças }\end{array}$} & \multicolumn{4}{|c|}{$\mathbf{N}^{\circ}$ de educadores (as) } & \multirow{3}{*}{\begin{tabular}{|c} 
Razão \\
educador(a) \\
criança
\end{tabular}} \\
\hline & & \multirow{2}{*}{ Manhã } & \multirow{2}{*}{ Tarde } & \multicolumn{2}{|c|}{ Volante } & \\
\hline & & & & Manhã & Tarde & \\
\hline $\begin{array}{l}\text { Berçário - } \\
4 \text { meses a } 1 \text { e } 11 \\
\text { meses }\end{array}$ & 16 & 3 & 3 & 1 & 1 & $1: 5$ \\
\hline $\begin{array}{l}\text { Grupo } 2- \\
2 \text { anos a } 2 \text { anos } \\
\text { e } 11 \text { meses }\end{array}$ & 14 & 2 & 2 & & & $2: 7$ \\
\hline $\begin{array}{l}\text { Grupo } 3- \\
3 \text { anos a } 3 \text { anos } \\
\text { e } 11 \text { meses }\end{array}$ & 15 & 1 & 1 & 1 & 1 & $1: 20$ \\
\hline $\begin{array}{l}\text { Grupo } 4- \\
4 \text { anos a } 4 \text { anos } \\
\text { e } 11 \text { meses }\end{array}$ & 20 & 1 & 1 & & & $1: 20$ \\
\hline $\begin{array}{l}\text { Grupo } 5- \\
5 \text { anos a } 5 \text { anos } \\
\text { e } 11 \text { meses }\end{array}$ & 20 & 1 & 1 & & & $1: 20$ \\
\hline $\begin{array}{l}\text { Grupo } 6- \\
6 \text { anos a } 6 \text { anos } \\
\text { e } 11 \text { meses }^{14}\end{array}$ & 20 & 1 & 1 & & & $1: 20$ \\
\hline
\end{tabular}

\section{- Rotina de horário e momentos}

A Creche/Pré Escola Oeste atende crianças com idade entre 4 meses e 6 anos e 11 meses, distribuídas em dois módulos. O Módulo I acolhe crianças de 4 meses até 3 anos e 11 meses, o Módulo II atende crianças de 4 anos a 6 anos e 11

\footnotetext{
${ }^{14}$ A razão adulto/criança dos 3 últimos grupos deve considerar os dois volantes, período da manhã e tarde
} 
meses. Para organizar todos os segmentos da creche existe uma rotina de horário e momentos.

Quadro 3 - Rotina de horário e momentos do ano de $2005^{15}$

\begin{tabular}{|l|l|l|l|}
\hline \multicolumn{2}{|c|}{ Módulo I } & \multicolumn{2}{c|}{ Módulo II } \\
\hline \multicolumn{1}{|c|}{ Horários } & \multicolumn{1}{c|}{ Momentos } & \multicolumn{1}{c|}{ Morários } & \multicolumn{1}{c|}{ Momentos } \\
\hline $6: 45$ & Ateliês & $6: 45$ & Ateliês \\
\hline $8: 30$ & Roda de conversa & $8: 30$ & Roda de conversa \\
\hline $8: 45$ & Lanche & $8: 45$ & Lanche \\
\hline $9: 00$ & Pátio & $9: 00$ & Pátio \\
\hline $10: 00$ & Momento de grupo & $10: 00$ & Momento de grupo \\
\hline $10: 45$ & $\begin{array}{l}\text { Berçário: almoço, } \\
\text { escovação de dentes } \\
\text { e descanso }\end{array}$ & $11: 45$ & $\begin{array}{l}\text { G4: almoço, } \\
\text { escovação de dentes } \\
\text { e descanso }\end{array}$ \\
& $\begin{array}{l}\text { G2 e G3: Almoço, } \\
\text { escovação de dentes } \\
\text { e descanso }\end{array}$ & $12: 00$ & $\begin{array}{l}\text { G5 e G6: almoço e } \\
\text { escovação de dentes }\end{array}$ \\
\hline $11: 00$ & Ateliês & $12: 00$ & $\begin{array}{l}\text { Descanso e propostas } \\
\text { tranqüilas }\end{array}$ \\
\hline $14: 30$ & Pátio & $14: 00$ & Momento de grupo \\
\hline $15: 30$ & Momento de grupo & $16: 45$ & $\begin{array}{l}\text { G4 jantar } \\
\text { G5 e G6 jantar }\end{array}$ \\
\hline $16: 30$ & $\begin{array}{l}\text { Bebês jantar } \\
\text { G2e G3 jantar }\end{array}$ & $\begin{array}{l}\text { 17:00 } \\
\text { Propostas diversas e } \\
\text { saída }\end{array}$ \\
\hline $17: 15$ & $\begin{array}{l}\text { Propostas diversas e } \\
\text { saída }\end{array}$ & $17: 00$ & \\
\hline
\end{tabular}

\section{- Aspectos da Rotina}

A chegada à Creche/Pré Escola Oeste é o momento precioso em que os pais, junto com seus filhos, podem ter um contato mais individualizado com os educadores e as crianças do mesmo módulo. Esse momento cria, também, a possibilidade de apreciação das produções infantis afixadas nas paredes, revelando a história do projeto de trabalho de cada grupo. Desta forma, os pais vão se aproximando das linguagens expressivas das crianças, podendo valorizálas.

${ }^{15}$ Durante o ano, a rotina de horário pode ser alterada, a partir das observações da comunidade. 
A chegada na creche deve ser um momento agradável, no qual as crianças sintam -se acolhidas. Na Creche/Pré Escola Oeste, todos os dias, as crianças podem trazer brinquedos de casa para compartilhar com seus amigos. Dadas as circunstâncias, esses brinquedos devem ser resistentes, o que exige a intervenção de familiares na sua escolha.

Considerando a localização da Creche/Pré Escola Oeste próxima ao trabalho dos pais e a variação dos horários de entrada dos funcionários (de acordo com cada unidade), temos uma flexibilidade de entrada das crianças de $6 \mathrm{~h} 45 \mathrm{~min}$ até às $9 \mathrm{~h}$.

A partir das 7h, já estão funcionando os ateliês, que se configuram como diversas propostas simultâneas (artes visuais, jogos de mesa, faz de conta e histórias). Nesse momento, as crianças têm oportunidade de exercer a escolha das propostas e interagir com crianças de idades diferentes, trocando idéias, compartilhando momentos, enfim, construindo conhecimentos e histórias.

Todos os dias, de manhã e à tarde, as crianças brincam no pátio com propostas dirigidas ou livres. É um momento em que as crianças de idades diferentes estão juntas, propício para as brincadeiras da cultura popular (ciranda, parlendas de corda, perna de pau, duro-mole, pega-pega, esconde-esconde, etc.) e outras atividades: brincar de túneis e castelos na areia, visitar as tartarugas, criar brincadeiras, fazer novos amigos em outros grupos, disputar espaços. No pátio há várias caixas plásticas, escorregadores, trepa-trepa que servem de apoio às brincadeiras. As educadoras supervisionam o pátio, garantindo a segurança física das crianças, mediando conflitos, "alimentando" descobertas e oferecendo materiais (cordas, penas de pau, etc.).

Há dois momentos no dia em que as crianças se reúnem por grupos da mesma faixa etária. Nesses momentos de grupo são feitas, diariamente, as rodas de histórias e de conversa, espaço privilegiado para discutir regras de conduta, 
compartilhar momentos, conhecer novas histórias, cantar músicas, contar "causos" e também elaborar projetos de trabalho.

O projeto de trabalho, iniciativa que reúne e articula diferentes ações, é considerado um dos principais veículos didáticos, envolvendo pais, educadores, funcionários e comunidade do entorno, cuja duração varia em consonância com a faixa etária, o interesse e o contexto no qual as crianças estão inseridas, possibilitando a resolução de problemas envolvendo ocorrências dentro e fora da sala de atividades ou da escola.

Na Creche/Pré Escola Oeste cada grupo decide com os educadores os assuntos a serem pesquisados no projeto de trabalho. As crianças buscam as informações necessárias em fontes variadas e vivas, como museus, parques, centros culturais, bem como em vários suportes tais como vídeos, livros, revistas, internet, entre outros. Privilegiam-se situações reais.

É muito interessante observar as crianças circulando por toda parte da Creche e no entorno, durante o percurso de um determinado projeto: procurando pequenos animais no pátio: tatu-bolas, minhocas e formigas; convidando a secretária para participar do plantio das hortaliças; observando a borboleta sair do casulo; revolvendo o resíduo orgânico com o zelador; montando aquário seguindo um manual de instrução; entrevistando pesquisadores e funcionários; buscando informações em livros científicos e na internet; conhecendo os museus; visitando estúdios e editoras; comprando gibis em bancas de jornal, enfim, relacionando-se com o mundo que as cerca de uma forma ativa e participativa.

No percurso do projeto, as crianças têm a possibilidade de expressar seus conhecimentos, suas buscas, hipóteses, descobertas, vivências, emoções e sentimentos, utilizando várias linguagens; seus trabalhos são expostos no saguão da Creche para que pais, funcionários e visitantes possam contemplá-los e valorizá- 
los. A exposição é um momento particularmente importante da aproximação crianças-comunidade, abrindo horizontes excepcionais para uns e outros.

Ao terminar um determinado projeto, alguns momentos são registrados em uma pasta-memória, contendo fotos, legendas, autores e co-autores e ilustrações das crianças. Assim, além das lembranças, a Creche tem registros concretos que, devidamente integrados à Oficina de Informação de que trataremos a seguir, servem de leitura a todos e referência especialmente às educadoras de outros grupos. A divulgação e o registro do trabalho possibilitam às crianças e à comunidade interna $\mathrm{e}$ externa evocarem os momentos significativos vividos. Desta forma, a identidade do grupo vai se constituindo, uma vez que todos se vêem nesse processo dinâmico que integra a escrita e outras formas de comunicação à vida e aos objetivos dos grupos envolvidos nos trabalhos.

Ao longo do dia são servidas quatro refeições, todas elas preparadas na Creche/Pré Escola Oeste, sob a supervisão da nutricionista de Divisão de Creches e da técnica em nutrição. Pais e crianças podem consultar o cardápio do dia no mural, localizado no saguão. Além disso, as educadoras lêem-no junto com as crianças, no momento de roda.

No descanso, depois do almoço, as crianças menores costumam dormir por um período que varia de acordo com o relógio biológico de cada uma. Os bebês dormem várias vezes ao dia. A partir dos quatro anos, na pré-escola, a maioria das crianças deixa gradativamente de dormir, mas há sempre um cantinho aconchegante para quem quiser descansar um pouquinho em qualquer momento do dia. Após o almoço, no módulo II, criou-se um momento com propostas mais tranqüilas para as crianças maiores que não desejam dormir e nem descansar.

A higienização, escovação de dentes e lavagem das mãos ocorrem diariamente, a fim de prevenir doenças e desenvolver atitudes, construindo habilidades para 0 
cuidado com seu próprio corpo. Para as crianças que ainda utilizam fraldas, a Creche garante pelo menos um banho diário para seu conforto.

\subsection{4 - Projetos que envolvem os diversos grupos de crianças}

\section{- Oficina de Informação}

A biblioteca batizada "Oficina de Informação" tem, como objetivo, promover o acesso e apropriação da cultura pelas crianças, pais e educadores/funcionários, bem como o desenvolvimento de competências necessárias ao acesso e apropriação de informações.

A Oficina de Informação tem um acervo de livros da literatura infantil, fitas de vídeo, enciclopédia, revistas, livros técnicos, CDs, computadores e jogos de CDROM. Toda semana as crianças escolhem um livro para levar para casa e podem, assim, desfrutá-lo com os pais, irmãos e vizinhos. Além disso, quinzenalmente, as crianças e os educadores escolhem, cada um, um livro para ler na roda com o grupo, gerando uma forma de circulação. Os pais e funcionários também podem, diariamente, escolher livros e vídeos para levarem para casa. Cada um cuida do registro de retirada e devolução dos materiais. A Oficina de Informação tem organização simples e regras acessíveis, visando à apropriação dos materiais com autonomia. O cuidado na concepção do espaço convida à imaginação. Além disso, o acervo é composto por diversos documentos produzidos pelas crianças e adultos (fotos, pastas-memória, livros, etc.).

\section{- Educação Ambiental}

Acreditamos que, desde cedo, a consciência de problemas ambientais, a formação de atitudes e a apropriação de valores ligados à preservação do planeta devem fazer parte das reflexões e ações nas instituições educativas. 
Uma das questões ambientais importantes do nosso cotidiano diz respeito à destinação do lixo que produzimos. É com o objetivo de refletir sobre essa questão e propor soluções que estão ao nosso alcance, que a Creche/Pré Escola criou, no ano de 1994, em parceria com o Projeto USP Recicla, o Projeto Lixo Zero, reordenando a destinação dos nossos resíduos: fizemos uma composteira, colocamos caixas coletoras de papel em todos os ambientes, fizemos questionamentos sobre o desperdício no uso de copos descartáveis, etc.

Todas as crianças, a partir de 2 anos de idade, e os funcionários participam do projeto, que já foi, por inúmeras vezes, alvo de notícias nos jornais e TV's. Também várias escolas e grupos vêm visitar à composteira.

\section{- Aniversário}

A data do nascimento das crianças é celebrada na Creche/Pré Escola Oeste, não para substituir uma atitude familiar, mas para garantir uma comemoração entre amigos que compartilham boa parte das suas infâncias. Esse momento é extremamente rico, propício para enfatizar o aspecto individual dentro do coletivo. Um grande painel no saguão de entrada, contendo expressões artísticas e fotos, confeccionado pelas crianças junto com as educadoras, no início de cada ano, anuncia os aniversariantes do mês. Essa forma de comunicação favorece que pais, crianças, funcionários tomem conhecimento dos aniversariantes existentes. Todas as crianças optam por uma preparação culinária no seu aniversário. Para auxiliá-las na escolha, a Creche/Pré Escola confeccionou uma pasta de receitas, contendo imagens de doces e salgados. Porém, as crianças têm o direito de escolher outras preparações, desde que seja possível realizá-las. Para os bebês comemorarem os seus aniversários, geralmente são preparados bolos, depois de uma consulta prévia aos pais para verificar suas preferências. 
A Creche/Pré-Escola Oeste procura comemorar os aniversários de cada criança na data do seu nascimento, mas, caso a data ocorra nos finais de semanas ou até mesmo nas férias, programa-se um dia para comemorá-lo. A princípio, a comemoração é feita somente para o grupo do aniversariante, porém, se ele desejar, poderá convidar outros adultos e crianças. Alguns pais mandam para 0 grupo lembrancinhas e bexigas. As crianças maiores ajudam na preparação do espaço para a grande festa.

\section{- Festas coletivas}

Páscoa, Festa Junina, Dia das Crianças e Natal são celebrações que, muitas vezes, envolvem nas suas preparações pais, crianças e funcionários. São momentos privilegiados para romper o cotidiano e compartilhar, em conjunto, datas significativas para a comunidade.

\section{- Saída para o Ensino Fundamental}

A saída das crianças da creche para o Ensino Fundamental merece uma atenção particular, uma vez que elas passaram boa parte de sua infância juntas, construíram vínculos afetivos bastante estreitos com pais, funcionários, educadores, crianças e com o próprio ambiente. Assim, a Creche construiu alguns rituais de passagem para que as crianças e as famílias enfrentem, com mais tranqüilidade, o desafio de ir para o Ensino Fundamental.

No $1^{\circ}$ semestre de cada ano, é realizada uma reunião com os pais do G6 (grupo das crianças mais velhas), sobre o trabalho de alfabetização que a Creche/Pré Escola Oeste desenvolve. Muitas vezes, os pais, para compreenderem o trabalho, evocam a própria experiência e revelam um grande estranhamento quando constatam que não se trabalha com cartilhas. É um momento de troca entre os pais e de grandes descobertas sobre a importância do letramento para o processo de alfabetização na Educação Infantil. 
No $2^{\circ}$ semestre de cada ano, as crianças que estão no G6 vão visitar uma escola pública, localizada nos arredores da Creche/Pré-Escola Oeste para entrevistarem a coordenadora pedagógica, professores e crianças. O grupo discute e registra as principais dúvidas e curiosidades sobre a escola (espaços, condutas, tempo).

O ritual de despedida é feito em dois momentos. No primeiro, as crianças fazem uma apresentação para os pais do G6, funcionários, educadores e crianças, de trabalhos realizados ao longo do ano. No mesmo dia, formaliza-se a entrega de uma agenda com nome, foto, endereço, telefone de todo o grupo e das educadoras. As crianças também levam para casa um livro de recordação, escrito por todo o segmento da Creche. Assim, podem relembrar momentos e entrar em contato com os amigos, quando a saudade aparecer. O segundo momento é "a grande dormida" na Creche, de sexta-feira para sábado, em data próxima ao término do ano. As crianças do G6 escolhem o cardápio do jantar e do café da manhã. Nesse evento, muitas brincadeiras e surpresas são planejadas pelas educadoras.

Um outro contrato que a Creche/Pré-Escola Oeste estabelece com as crianças é retornarem no final do ano seguinte, para contar a experiência da $1^{\text {a }}$ série, às crianças do então G6. Essa prática é algo que as crianças esperam ansiosas, pois é a possibilidade de rever os espaços, amigos e reviver as brincadeiras. Eventualmente, ao longo do ano, a Creche também recebe algumas visitas dessas crianças. 


\subsection{5 - Recursos Humanos}

\section{- Formação inicial}

Desde a inauguração da primeira Creche na Universidade de São Paulo, a equipe central, atualmente denominada de Divisão de Creches, exigiu para contratação de educadores a formação mínima com magistério, ou mesmo ensino médio, e muitos cursavam o ensino superior.

A Lei de Diretrizes e Bases da Educação Nacional promulgada no ano de 1996, dispõe no título VI, art.62 que:

A formação de docente para atuar na educação básica far-se-á em nível superior, em curso de licenciatura, de graduação plena, em universidades e institutos superiores de educação, admitida, como formação mínima para o exercício do magistério na educação infantil e nas quatro primeiras séries do ensino fundamental, a oferecia em nível médio, na modalidade formal.

Podemos constatar que a Divisão de Creches, antes mesmo da recomendação da LDB, demonstrou, a partir de suas contratações, a importância da formação inicial para atuação junto às crianças pequenas. Atualmente, a Divisão de Creches realizou alguns ajustes, de acordo com a LDB, dentre eles, a não contratação de educadores com ensino médio. Até o presente momento, a Creche/ Pré Escola Oeste possui um quadro com 25 educadores, sendo que somente 2 educadores não têm magistério e nem curso superior.

\section{- Formação em Serviço}

A formação continuada é fundamental para construirmos um trabalho de qualidade e com sensibilidade na Educação Infantil. A Divisão de Creches, desde a construção da primeira unidade, privilegiou essa prática criando oportunidades para a discussão do trabalho, com encontros semestrais e paradas mensais, além 
das reuniões regulares feitas semanalmente pelos técnicos, pedagogo e/ou psicólogo de cada Creche.

A Creche/Pré Escola Oeste, ao longo de 15 anos, vem propondo a formação em serviço, não só para os educadores, mas para os vários segmentos da instituição, funcionários da cozinha, limpeza, zeladoria e secretária que atuam junto às crianças, direta ou indiretamente. Dentro destes princípios, a Creche/Pré Escola Oeste tem como principais objetivos:

Formar e construir o coletivo institucional;

Refletir e socializar as práticas desenvolvidas em todos os segmentos da Creche/Pré Escola Oeste: pedagógico, psicológico, saúde e nutrição;

Aprofundar teoricamente temas importantes, eleitos a partir de processo avaliativo permanente junto às equipes de trabalho da Creche;

Elaborar instrumentos para registros;

Compartilhar inquietações e estresse emocional do cotidiano;

Planejar e registrar o trabalho pedagógico, de nutrição, de limpeza e saúde;

Participar de eventos culturais.

\section{- Jornadas de Formação Continuada Semestral}

Ocorrem no início de cada semestre, com duração de 3 a 5 dias úteis e a finalidade de organizar a Creche, elaborar o planejamento e discutir questões do coletivo. No início do ano essa jornada é organizada e ministrada particularmente por cada creche, de acordo com suas necessidades específicas; em julho, tal tarefa é de competência da Divisão de Creches, que promove um encontro das creches que administra, para trocar experiências, ouvir palestras e confraternizar. Nesses dias, as instituições não recebem as crianças. 


\section{- Formação Continuada Mensal}

Agendadas no início de cada ano, as reuniões geralmente acontecem às sextasfeiras. Nesses dias, as creches não atendem às crianças. Todos os funcionários comparecem e são programadas oficinas, palestras, reuniões em grupos diversificados, de acordo com os temas em questão. É um momento fundamental para a construção do coletivo, pois todos os funcionários estão reunidos no mesmo horário, discutindo diversos assuntos, que vão desde o trabalho junto às crianças até normas de convivência entre os adultos. Também, nesses dias, é reservada 1 hora para os funcionários discutirem questões específicas da vida funcional na Universidade.

\section{- Reunião de dupla ${ }^{16}$}

Realizada semanalmente, no horário da $12 \mathrm{~h}$ às $13 \mathrm{~h}$, com a participação das educadoras da manhã e da tarde de cada grupo de crianças e uma das técnicas (pedagoga ou psicóloga).

Nas reuniões pedagógicas discute-se encaminhamento para os planejamentos, organização de espaços e agrupamentos. Os relatórios de grupo, que descrevem momentos significativos dos projetos de trabalhos, destinados às famílias, também fazem parte das discussões. As reuniões de pais são cuidadosamente elaboradas pelas duplas, inclusive muitas delas, além de ter vídeo e fotos registrando o processo dos projetos, oferecem oficinas para os pais participarem. Essas oficinas, muitas vezes, contribuem para os pais compreenderem o trabalho e as produções artísticas das crianças.

\footnotetext{
${ }^{16}$ Tanto as reuniões de dupla como de módulo são contempladas dentro das seis horas diárias, pois não existe remuneração como nas escolas públicas. Isso exige um grande esforço para organizar as substituições dos educadores no módulo.
} 
As reuniões com a psicóloga abordam muitas questões sobre as relações entre criança-crianças, criança-educador, criança-família e, especialmente, um olhar mais individualizado para uma determina criança. Os relatórios individuais de cada criança também são discutidos nesse espaço.

\section{- Reunião de módulo}

Esta reunião garante a participação dos educadores do período da manhã e da tarde de cada módulo (módulo I - crianças de 0 a 3 anos e módulo II - crianças de 4 a 6 anos), no horário das $12 \mathrm{~h}$ às $13 \mathrm{~h}$.

O formato, a metodologia e a coordenação das reuniões de módulos variam de acordo com a temática elegida pelo grupo junto aos técnicos. Um exemplo inovador ocorreu em 2002, a partir de uma leitura apurada, tanto dos técnicos quanto dos educadores, da necessidade de aprofundar estudos sobre o ambiente sócio-moral, resolveu-se, então, dar outro formato a essas reuniões. Assim, as reuniões transformaram-se em grupos de estudos por determinado período, no qual cada grupo de educadores assumiu um texto para apresentar aos parceiros. As reuniões também são momentos para organizar a rotina, focando espaço e tempo.

Outra metodologia, que a equipe de coordenação vem utilizando nas reuniões, é a possibilidade de os educadores evocarem momentos vividos da própria infância. Essa forma possibilita aos educadores que se aproximem da infância, estabelecendo relações entre o passado, presente e o futuro, além de tomarem consciência se estão reproduzindo vivências junto às crianças que não condizem com o contexto histórico.

Uma outra prática significativa é a documentação das reuniões realizadas pelos próprios educadores. O educador responsável tem o compromisso de elaborar uma síntese da reunião, que será lida no próximo encontro. Esse registro é 
colocado numa pasta para que todos possam ter acesso. Desta forma, o grupo vai se percebendo como protagonista, nesse processo dinâmico que é o trabalho em instituição educativa infantil.

\section{- Momento de planejamento}

Horário destinado aos educadores para reorganizar os planejamentos, com duração de aproximadamente uma hora semanal, no início da manhã ou no final da tarde. É bom ressaltar que os educadores recriam o planejamento diariamente, a partir do movimento das crianças. Essas chamadas "dicas" das crianças são registradas na parte de trás do planejamento e transformadas, muitas vezes, em propostas.

\section{- Momento de registro}

Semanalmente, os educadores dos grupos registram informações preciosas sobre o desenvolvimento de cada criança. Esse registro também é fundamental para a elaboração dos relatórios individuais. A Creche/Pré Escola Oeste tem um "caderno de registro" para cada grupo, com diversos campos: rotina de horário, calendário anual, registros para reunião de dupla e módulo, reunião de pais e espaço com o nome de cada criança para as informações colhidas no decorrer do ano. Somente o caderno de registro do berçário tem um campo destinado à comunicação entre os dois períodos.

- Reunião das equipes de nutrição, limpeza, saúde, secretaria e zeladoria

Com a duração de uma hora, ocorrem, quasesempre, no período da tarde e não têm periodicidade previamente definida. Geralmente, essas reuniões são coordenadas pela diretora, exceto quando é algo muito especifico como encontros com a nutricionista, ou mesmo com especialistas da área de saúde. 


\section{- Reunião inter-equipes}

Ocorrem sempre que necessário, com a participação de funcionários de quaisquer equipes para a discussão de questões e acompanhamento de processos de trabalho. Há ocasiões em que são convidados profissionais externos à Creche, para participar e discutir junto com os educadores/funcionários sobre intervenções no desenvolvimento do trabalho educativo.

\section{- Reunião extraordinária}

Pode ser solicitada por qualquer profissional, a qualquer momento, sempre que for necessário.

\section{- Trocas informais}

Diariamente, os profissionais trocam informações sobre o trabalho e as crianças, principalmente nos momentos que os educadores mudam de turno. Além disso, as educadoras do Berçário registram o dia-a-dia, incluindo ocorrências com as crianças.

\section{- Reunião de supervisão}

Também são feitas reuniões de supervisão com a equipe técnica da Divisão de Creches, sobre necessidades do serviço, questões administrativas e para discussões mais amplas.

\section{- Saúde dos funcionários}

Pelo menos duas vezes por semana, os funcionários da limpeza, cozinha e os educadores do berçário participam de orientações e exercícios para prevenção de doenças como tendinites, dores na coluna, dentre outros problemas gerados pelo 
excesso de peso, mal distribuído. Esse acompanhamento dos funcionários é realizado por estagiários, geralmente de fisioterapia ou terapia ocupacional.

\section{- A relação Creche/Pré Escola Oeste e família}

A Divisão de Creches e, por conseguinte, a equipe da Creche/Pré Escola Oeste acredita que, para as crianças ficarem tranqüilas e poderem desfrutar do ambiente da Creche, é fundamental que sejam construídos vínculos de confiança e respeito com as famílias. Por isso, trabalham com a concepção de Creche/Pré-Escola aberta, buscando o diálogo com as famílias.

\section{- Contato com famílias e crianças novas}

O primeiro contato que a Creche estabelece com as famílias das crianças novas é a entrevista da matrícula e a avaliação médica. Após a realização de todas as matrículas, é agendada uma reunião para que os pais conheçam os representantes de vários segmentos da Creche/ Pré-Escola, o projeto pedagógico e as regras internas da instituição.

Ao longo do ano são realizadas outras reuniões com os pais, com diferentes finalidades: contar sobre o trabalho realizado, ouvir palestras sobre temas de interesse, discutir questões relativas ao funcionamento da Creche.

\section{- Associação de Pais e Funcionários da Creche/Pré-Escola Oeste}

Desde 2000, a Creche/ Pré-Escola conquistou um outro fórum de discussão: a Associação de Pais e Funcionários, que vem contribuindo significativamente para a construção da sua Proposta Pedagógica. 


\section{5 - Dispositivos de informação da Creche/Pré Escola Oeste}

\subsection{1 - A primeira Biblioteca da Creche/Pré Escola Oeste}

A Creche/Pré Escola Oeste já foi planejada para ter uma pequena biblioteca. Possuía, então, um acervo de livros e jogos dispostos em prateleiras organizadas da seguinte forma: contos e lendas, revistas, pesquisas, histórias, jogos e poesias. Também tinha pequenas mesas e cadeiras para que as crianças pudessem realizar suas leituras. De acordo com o Relatório Semestral da Creche Oeste de 1991, a biblioteca funcionava como descreveremos a seguir:

Foi organizada uma rotina semanal na qual cada grupo iria à biblioteca 2 vezes por semana, a partir do grupo 1, uma vez no período da manhã e outra à tarde. Assim, ficaram garantidos momentos em que as crianças puderam ouvir histórias contadas pelos educadores, folhear e ler vários livros. Além disso, a biblioteca ficou configurada como o espaço do ateliêe ${ }^{17}$ de histórias do Módulo II.

Apesar dos esforços na construção do trabalho na biblioteca, verifiquei no Relatório da Creche Oeste, de 1991, que havia um índice muito grande de livros rasgados pelas crianças e que, por essa razão, a equipe planejou a retirada dos livros para criar um acontecimento.

Após a "fuga" dos livros, por estarem sendo maltratados [...], os
livros enviaram uma carta a cada criança do Módulo II e dos Grupos
I e II, anunciando seu retorno. Todo este processo promoveu muita
reflexão por parte das crianças e também muita euforia,
principalmente por ocasião da volta dos livros.
Outro grande evento foi a escolha do nome da biblioteca. A
princípio, foram escolhidas sugestões entre as crianças, pais e
funcionários. A partir de então, iniciou-se uma campanha eleitoral
dos nomes mais sugeridos. Foram produzidos panfletos com defesa

17 Os ateliês são propostas diversas e simultâneas, em que as crianças de várias idades juntas escolhem as atividades de acordo com seu interesse e desejo. 
de cada um, que foram muito discutidos entre as crianças. As cédulas eleitorais traziam todos os nomes, candidatos e, após a apuração, crianças e adultos haviam eleito CASTELO BRILHANTE.

No Relatório Anual de 1992 foram registradas algumas estratégias, utilizadas para sensibilizar as crianças sobre a importância de conservar os livros e caminhos para ampliação do acervo:

\begin{abstract}
Iniciamos em julho, com a chegada de educadores novos, a reorganização dos nossos livros e do espaço da biblioteca. O livrotombo foi atualizado e constatamos a perda de muitos volumes. Novos critérios de organização foram definidos e foi feito um trabalho com cada grupo de crianças para que pudessem se apropriar dos novos combinados. Nessa ocasião toda a história da nossa biblioteca foi resgatada e cada grupo sugeriu idéias sobre como ampliar o número de volumes. Temos atualmente por volta de 200 volumes, sendo que muitos em mau estado. As crianças gostaram muito da idéia de ter uma Biblioteca Circulante na creche, para poderem levar livros para casa. Iniciamos em outubro a $1^{\underline{a}}$ Campanha do livro Infantil. Arrecadamos 28 volumes entre livros novos e usados, o que não nos coloca numa situação muito diferente da que estávamos. Pretendemos retomar a continuidade deste trabalho em 1993, buscando novas estratégias.
\end{abstract}

A partir dos relatórios pude constatar que, naquela época, não havia uma política de reposição e ampliação dos materiais, além de limitações de pessoal para assumir o espaço da biblioteca. Para reposição e ampliação dos livros, o grupo teve que realizar uma campanha com a finalidade de compor o acervo. É sabido que, com esse tipo de campanha, corre-se o risco de receber livros sem qualidade ou inadequados para o uso de crianças pequenas; este foi o caso de um pai que enviou à Creche quadrinhos pornográficos. Para selecionar os livros doados, recorria-se ao bom senso, pois não se tinha competência específica para selecionar os livros.

Esse relatório também revela que a reorganização da biblioteca só se deu após a chegada de educadoras novas, demonstrando que não havia um profissional responsável pelo local. O fato de as crianças utilizarem a biblioteca sem a sua inauguração e um nome para o espaço, parece indicar que o grupo não teve a 
dimensão do significado da celebração e da importância de uma marca de identidade para o local.

A classificação dos livros por gêneros e o fato de não haver outros recursos informativos, levou-me a perceber que a equipe da Creche Oeste estava, naquele momento, preocupada em promover um ambiente alfabetizador, oferecendo às crianças diversas tipologias textuais.

Nesse período, houve várias dificuldades nas relações entre os funcionários e as crianças. A Creche enfrentava muitos problemas administrativos e relacionais, que a levaram a viver momentos de grande conturbação, refletidos largamente no comportamento das crianças, que se tornaram rebeldes, desafiando a autoridade dos adultos, transgredindo normas, brigando entre si.

Os livros da biblioteca e os trabalhos expostos eram rasgados. Os educadores não sabiam como agir diante daquela situação e, muitas vezes, optavam por não olhar as transgressões das crianças.

Em 1992, a rotatividade das educadoras girava em torno de 58\% do quadro, demonstrando que havia grande mal-estar instalado na Creche e que transparecia também fora da Creche (SEKKEL, 1998). As atitudes das crianças refletiam os problemas com os educadores.

Não restou nenhum registro sobre os trabalhos desenvolvidos na biblioteca, no ano de 1993. E o nome da biblioteca "Castelo Brilhante", desaparece do espaço da Creche, talvez levado pelos que saíram e pouco valorizado pelos funcionários que ficaram.

Em setembro de 1993 foi aberta a seleção para preencher a vaga de pedagoga (depois de dois anos sem que fosse autorizada a contratação). Cheguei para coordenar o trabalho pedagógico, com a experiência de 6 anos como educadora 
na Creche Central, tendo o grande desafio de construir vínculos de confiança com o grupo de educadores. No ano de 1994, a diretora da Creche recebeu uma proposta de trabalho mais vantajosa, pediu demissão e foi substituída, tempos depois, pela psicóloga Marie Claire, que permaneceu na direção da Creche.

A equipe de coordenação investiu, nesse período, na construção de um vínculo de confiança com todos os protagonistas que faziam parte da comunidade Creche/Pré Escola Oeste (pais, funcionários, crianças). O empenho foi grande e o grupo considerou que esse foi "o ano da quebra das barreiras". O Relatório Anual da Creche aponta a melhoria na interlocução conquistada pelo grupo.

O que mais marcou este ano, foi a mudança significativa na forma das relações entre educadores, coordenação e crianças, que se traduziu num ambiente mais propício ao desenvolvimento do trabalho educativo. Isso pôde ser avaliado pela equipe (quebra das barreiras, satisfação com o trabalho...)

De acordo com Sekkel, (1998, p.45 e 46) dois projetos marcam a historia da Creche/Pré Escola Oeste e um deles inclui a Oficina de Informação:

O Lixo Zero e a Oficina de Informação. Ambos os projetos vão contribuir, ao lado do esforço da equipe de coordenação, para construir uma relação de compromisso entre os funcionários para a mudança da auto-imagem da Creche Oeste e de todos que nela trabalham."

\subsection{2 - Descrevendo o objeto de pesquisa: Oficina de Informação}

Em novembro de 1994, a Oficina de Informação foi inaugurada. No Relatório de Atividades da Divisão de Creches $^{18}$ de 1994 consta que além das caracterizações já mencionadas, encontra-se também procedimentos para a implantação do projeto da Oficina de Informação:

18 Relatório de atividades é um documento elaborado pelas creches para a Divisão de Creches, que registra e analisa o que foi realizado no ano. 
- Preparação de dois técnicos da Divisão (pedagogo e prof. Educação Física), através do curso "Mediação da Informação em Educação" (360 horas), ministrado na ECA, pelo Depto. de Biblioteconomia;

- Levantamento dos recursos didáticos e técnicos já existentes nas creches;

- Apresentação do projeto aos funcionários da Creche Oeste;

- Apresentação da Oficina de Informação às crianças e aos pais;

- Inauguração da Oficina com o Seminário "Serviços de Informações Educativos".

Para o funcionamento da Oficina de Informação havia necessidade de recursos materiais e humanos que a pesquisa financiaria, por um tempo; mas o objetivo do projeto era que a Creche/Pré Escola Oeste assumisse integralmente o trabalho.

Dada a natureza inovadora do Projeto tivemos - Direção e Coordenação Pedagógica - uma certa dificuldade inicial de compreender a nova concepção da biblioteca em gestão. Cabia à Divisão de Creches, por meio de profissionais indicados para tanto, incluir-nos nas concepções, uma vez que tais profissionais seguiam o curso de especialização intitulado: "Mediação da Informação em Educação" oferecido pelo PROESI, bem como interlocução pedagógica com a pesquisa. Por isso, não participamos dos primeiros contatos do PROESI com a Divisão de Creches e nem freqüentamos o curso.

A diretora da Creche e eu teríamos o papel de mediadoras entre as bolsistas do PROESI e, principalmente, as educadoras, sendo essa interlocução fundamental para a construção de práticas e reflexões do cotidiano.

O espaço destinado para instalação da Oficina de Informação deveria ser a biblioteca, que era uma sala relativamente pequena. Mas, por razões operacionais, Claire e eu resolvemos ocupar esse espaço, pois ficaríamos mais próximas das crianças e educadoras, o momento exigia aquela mudança. Assim, foi oferecida para a instalação da Oficina uma sala de reuniões, $6 \mathrm{~m}$ por $4 \mathrm{~m}$, um pouquinho maior que a primeira, porém com um problema; localizava-se no piso superior da Creche. 
A equipe do PROESI alertou para as dificuldades de locomoção especialmente com as crianças menores. 17 degraus de escada, insuficiência de proteção no percurso e nas janelas do andar superior. Além disso, as crianças não tinham acesso livre à Oficina de Informação, tendo que cruzar toda área da administração, diariamente. Claire e eu acreditávamos que esse tipo de obstáculo, era aparente e não seria empecilho para que as crianças menores subissem ao espaço, pois o percurso seria uma verdadeira aventura. Ficava, claro, a dificuldade de irem sozinhos. Apesar dessas questões, fomos adiante.

O ambiente da Oficina de Informação foi concebido pela Equipe do PROESI, considerando os seguintes conceitos: sociabilidade, autonomia, ludicidade, diversidade e afetividade. Nesses primeiros momentos, a equipe do PROESI esteve bem perto da Creche/Pré Escola para a instalação da Oficina de Informação e algumas questões foram propostas para os educadores e equipe técnica definirem:

- quantas vezes as crianças subiriam à Oficina de Informação?

- como seria a implantação de rotinas para retiradas de livros para casa e sala?

- qual seria o prazo de devolução dos livros que as crianças levariam para casa?

- qual o local de devolução dos livros?

- como as educadoras deveriam utilizar a Oficina?

- como os pais e funcionários também poderiam desfrutar do espaço?

Assim, o grupo dedicou-se a pensar em alguns caminhos para organizar a rotina de empréstimos de livros e idas à Oficina de Informação, com o compromisso dos dois períodos, manhã e tarde, viverem essa experiência. A equipe resolveu que cada grupo subiria duas vezes por semana, por um período de 30 min, para escolher os livros para casa e sala. E num outro momento, por volta de $1 \mathrm{~h} 30 \mathrm{~min}$ 
para desfrutar do espaço (ouvir histórias, assistir filmes, ouvir músicas, etc.). Somente o berçário não iria escolher os livros para sala e para casa, mas as educadoras teriam o compromisso de levá-los à Oficina de Informação.

Na prática, fomos percebendo os descompassos dessa organização em relação aos horários para empréstimos de livros para sala e casa. Percebeu-se que, durante as escolhas dos livros na Oficina de Informação, as crianças necessitavam de um tempo maior, já que muitas olhavam caixa por caixa e às vezes, iniciavam suas leituras no próprio local; depois, guardavam-nos novamente, recomeçando suas escolhas. Isso ocasionava um tumulto, pois o próximo grupo estava chegando e tinha que esperar sua vez no corredor ou, para evitar esta situação, as bolsistas (Toninha ${ }^{19}, \mathrm{Bia}^{20}$ e Cíntia ${ }^{21}$ ) corriam para o módulo para avisar que as crianças ainda estavam escolhendo os livros...

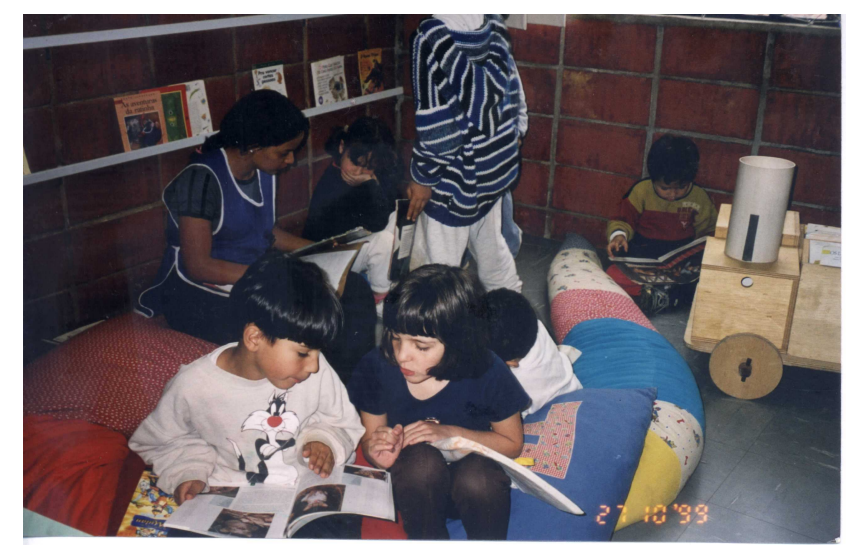

A partir do movimento das crianças, resolvemos mudar a organização dos horários para os grupos escolherem os livros confortavelmente, sem a pressão dos adultos preocupados em cumprirem horários rígidos. Ao considerar que a grande maioria das crianças freqüenta a Creche/Pré Escola Oeste em período integral, a equipe da Creche resolveu organizar a rotina para que as crianças fossem à Oficina de

\footnotetext{
19 Antonia de Souza Verdini, pedagoga, pesquisadora do PROESI;

${ }^{21}$ Maria Beatriz Savoldi Armando

${ }^{22}$ Cíntia Shukusawa, alunas de graduação da USP e bolsista de iniciação científica, CNPq.
} 
Informação no período da manhã, para pesquisas relacionadas aos projetos desenvolvidos em sala e, no período da tarde, para os empréstimos de livros e outras possíveis propostas.
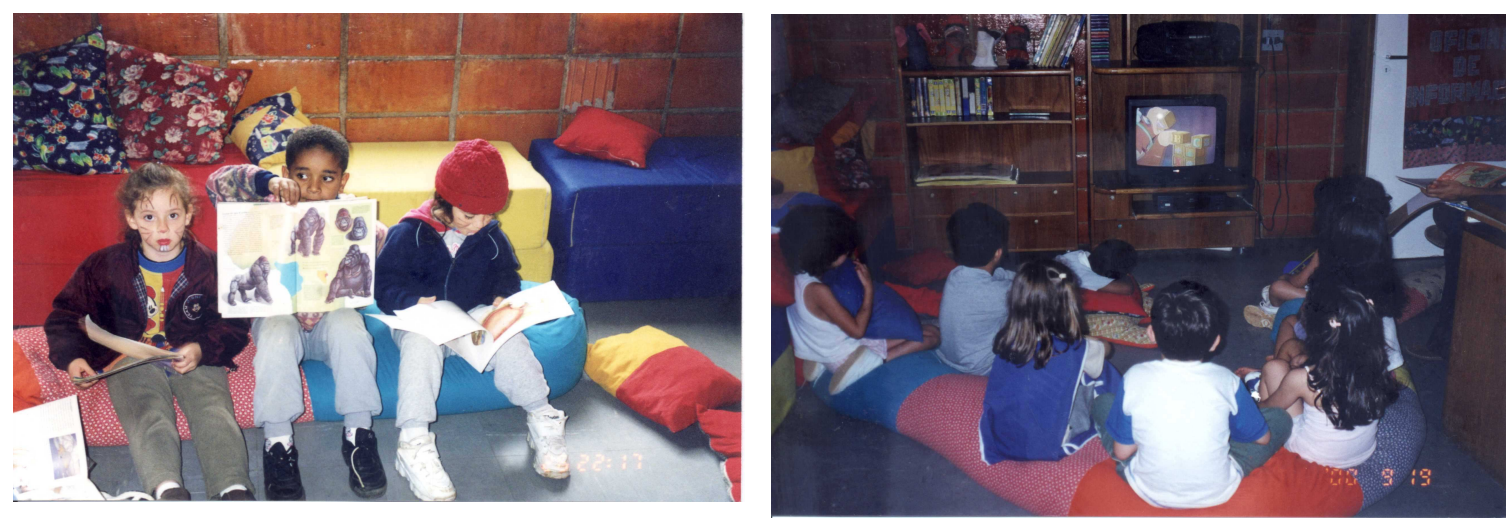

Para a devolução dos livros trazidos de casa, os funcionários da Creche/Pré Escola Oeste e a equipe do PROESI instalaram um baú, no saguão. Mas, com o passar do tempo, as bolsistas do projeto sinalizaram as dificuldades de dar baixa nos livros que as crianças traziam de casa, pois não havia uma identificação por grupo. Então, as equipes criaram um painel de pano com bolsões em que as crianças depositavam os livros, de acordo com o grupo. Esse painel é utilizado até hoje.

O tratamento técnico, bem como a preparação dos materiais foram feitos no PROESI. Para isso, foi criado um sistema de organização especial, considerando as características do público infantil, mas seguindo padrões de organização documentárias reconhecidas. Por falta de recursos institucionais, a quase totalidade do acervo foi doado pelo Professor Dr. Edmir Perrotti, bem como foram obtidos por doações outros recursos materiais. Além disso, várias pessoas trabalharam voluntariamente, a pedido da equipe do PROESI e, juntos, todos, realizaram o que se propunha. Em novembro de 1994, várias pessoas da equipe do PROESI vieram para concluir a preparação da Oficina de Informação, dando os 
últimos retoques. Todos os segmentos da Creche participaram na preparação do coquetel e arrumação do pátio para a recepção dos pais, crianças, funcionários, equipe da Divisão de Creches e outros convidados.

E, como um sonho realizado, o espaço da Oficina de Informação estava totalmente transformado, os livros estavam acondicionados em várias caixas de plástico colorido, distribuídas nos cantos de uma parte da sala. Havia dois grandes expositores feitos com trilho de cortina, que ocupavam uma boa parte da parede. As almofadas com formato de bichos, cobra, sapo e tartaruga tornavam o espaço encantador e instigador do imaginário. Três painéis de feltro foram confeccionados, representando uma floresta. Um mural com bolsos transparentes contendo diversas fotos das crianças e educadoras compunha também o espaço. A televisão, o vídeo e as fitas estavam colocados à disposição das crianças em uma mesinha. Atrás da porta, estavam, nas prateleiras, os livros de consultas para as educadoras.

A alegria da equipe do PROESI irradiava nos quatro cantos da Creche, e nascia, principalmente nas educadoras mais antigas de casa, uma esperança de mudança. Após a inauguração, as educadoras ficaram animadas com a parceria. O Relatório Anual da Creche/Pré Escola Oeste de 1995 conta o grande investimento que as equipes fizeram após a inauguração da Oficina de Informação:

Tudo que aconteceu na Oficina de Informação foi acompanhado com muita atenção pelas duas estagiárias do PROESI: Toninha, que é a coordenadora da Oficina de Informação, e Cintia, também responsável pelas publicações.

Foram necessárias reuniões quinzenais a fim de cuidar da afinação necessária ao cruzamento dos objetivos da Creche e da Oficina. Alguns dos principais resultados alcançados:

- implantação de rotinas para retirada de livros para a biblioteca de sala;

- implantação de rotina semanal para os empréstimos domiciliares;

- incentivo à participação das famílias na retirada, leitura e cuidados com os livros; 
- criação do OFINFORMA Informa: Boletim informativo sobre o desenvolvimento dos trabalhos

- criação de pequenos acervos e vídeo;

- investimento na formação dos educadores sobre a arte de contar histórias;

- participação no I Simpósio Serviço de Informação em Educação;

- criação e manutenção cuidadosa de um espaço convidativo à fantasia e cujos reflexos puderam ser percebidos em vários lugares da Creche.

Também consta no Relatório a necessidade de que houvesse educadores da Creche participando mais ativamente e se apropriando das rotinas de manutenção da Oficina.

Na prática, porém, a parceria não foi tão fácil assim. Já nos primeiros dias após a inauguração, uma das educadoras volantes resolveu confeccionar um gigantesco Menino Maluquinho para ilustrar a história que contaria na Oficina de Informação, deixando-o depois no espaço. A supervisora das bolsistas, com cuidado, disse que verificaria com o coordenador do PROESI a possibilidade de deixar a imagem na Oficina. Em virtude da pesquisa que estava sendo feita, toda e qualquer intervenção no espaço, segundo ela, deveria ser discutida pelos pesquisadores. Tal fato gerou algumas dificuldades, pois neste momento a Creche/Pré-Escola Oeste buscava compreender novos ângulos no que vinha desempenhando, buscava construir uma nova identidade. Penso até hoje, o motivo pelo qual não discutimos melhor essa questão das relações entre pesquisa/serviço e seus membros. Talvez nos faltasse experiência e maturidade em projetos dessa ordem.

As propostas realizadas na Oficina, além dos empréstimos para casa e sala, eram desenvolvidas pela supervisora das bolsistas, que contava belas histórias, com o intuito de fazer um trabalho de formação em serviço. A idéia, apesar de interessante, não era adequada para o momento que a Creche/Pré Escola Oeste estava vivendo, pois as educadoras acabavam delegando às bolsistas a organização da roda de histórias. 
Os conflitos foram diversos com as bolsistas, que questionavam a falta de limpeza do espaço da Oficina, apontavam algumas posturas adequadas e inadequadas dos educadores. Do outro lado, as educadoras também questionavam a atuação das bolsistas. Eu, como coordenadora, tinha o papel de mediar os conflitos e, muitas vezes, a vontade foi de "jogar tudo para os ares". Mas as crianças foram demonstrando o significado da Oficina de Informação na construção de leitores, não só de livros, mas de produtores de cultura, além do afeto colocado naquele ambiente.

A propósito, vale relatar um episódio ilustrativo do ganho que foi a Oficina de Informação para as crianças. A Creche/Pré Escola Oeste propõe uma atividade para as crianças de seu último grupo visitar escolas de $1^{\circ}$ grau, para que elas possam tirar suas dúvidas junto aos professores, coordenadores e alunos. Em uma dessas visitas, as crianças perguntaram para a coordenadora pedagógica: “Onde está a Oficina de Informação?” Ela, evidentemente, não compreendeu. Então uma das educadoras traduziu: "É um espaço semelhante a uma Biblioteca." A coordenadora, rapidamente, pegou um molho de chaves e levou o grupo até um local protegido com grades, que era a biblioteca. As crianças ficaram felizes, mas logo tiveram uma grande decepção ao contemplarem o espaço. "Isso não é Oficina! não têm almofadas, caixas de livros, televisão, vídeo..." A coordenadora da escola respondeu: "Lógico que temos livros, estão nas estantes". As crianças se dirigiram até elas, mas logo foram advertidas: "Essa não é a estante para a idade de vocês".

No ano de 1995, a Oficina de Informação comemora o seu primeiro aniversário, em grande estilo. Essa festa foi organizada pela Creche/Pré Escola Oeste e equipe do PROESI. Os grupos elaboraram um teatro para ser apresentado no momento da festa e foi feito um confeiteiro da equipe dos restaurantes da USP, somente para decorar o bolo da festa com a imagem do Ofin. No convite de aniversário, as bolsistas do PROESI narraram a história da Oficina de Informação da seguinte forma: 


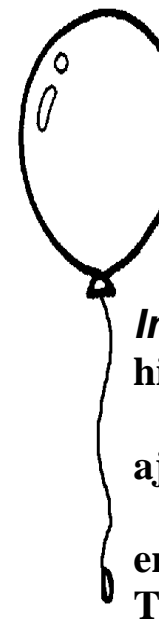

\section{FESTA DE ANIVERSÁRIO}

Um ano inteirinho passou! Com isso, a Oficina de Informação ao comemorar o $1^{\circ}$ aniversário, já tem sua própria história para contar.

O OFIN, todo prosa, fazendo pose de velho narrador, sempre ajeitando os óculos, vai contando para quem quiser ouvir:

- A Oficina de Informação foi instalada na Creche Oeste, em Novembro de 1994, num dia de grande festa! Vocês se lembram?

Teve música, brincadeiras e até coquetel. Eu não tinha nascido ainda, mas vi nas fotos que estão em exposição. Fui produzido depois, para dar informações da Oficina. Tenho até viajado! Meu passaporte são palavras, os relatos que eu faço no Boletim OFinFORMA, na Gazeta Oeste, nos murais, nos Simpósios. Acho até que vou ficar famoso! Desculpem a vaidade.

Vocês sabem quantos empréstimos de livros já foram feitos na Oficina? 2.200 bastante, não? Sem contar com as fitas-cassete que são emprestadas mais nos finais de semanas.

Eu fico tão contente, cada vez que alguém sai da Oficina de Informação, levando uma historia para "curtir"! Os pais das crianças precisam me visitar com mais freqüência, compartilhar a emoção dos seus filhos na escolha do livro para ler. São olhos e dedinhos que buscam sonhos... fantasias... conhecimento... mergulhando em caixas que ficam ainda mais coloridas com a imaginação!

Muitas vezes as escolhas são bem definidas: "quero o livro que fala do mar"; ou então, "onde está o livro do circo"? e do “ passarinho da asa quebrada"? Outro dia, uma criança disse: "gosto dos livros que falam de Amor". Ai, ai! Não é pra ficar vaidoso??! Também nas sessões de vídeo, as crianças têm suas preferências! $\mathbf{E}$ entram nas histórias, como se fossem personagens! Depois, continuam no mundo do "faz de conta", ouvindo e contando outras historias, nos "momentos de grupo", nas rodas, nas brincadeiras...

Bem, continuando a minha historia, vocês sabem que temos recebido muitas visitas aqui? É, sim. Gente de fora, de outras cidades, de longe! Vêm para saber como pode ser um serviço de informação para crianças e como se educa através dele. Até na França já somos conhecidos!

Para o próximo ano, muitas coisas vão acontecer. Visitas de escritores...exposições...estudos... e então, teremos mais historia para contar. Por enquanto, vamos cantar:

Parabéns a você,

Nesta data querida,

Muitas felicidades,

Muitos anos de vida.

Vivaaaaaa!!!

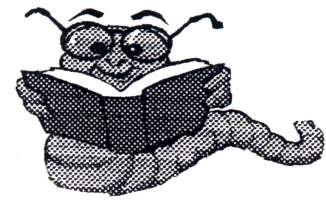

OFIN 

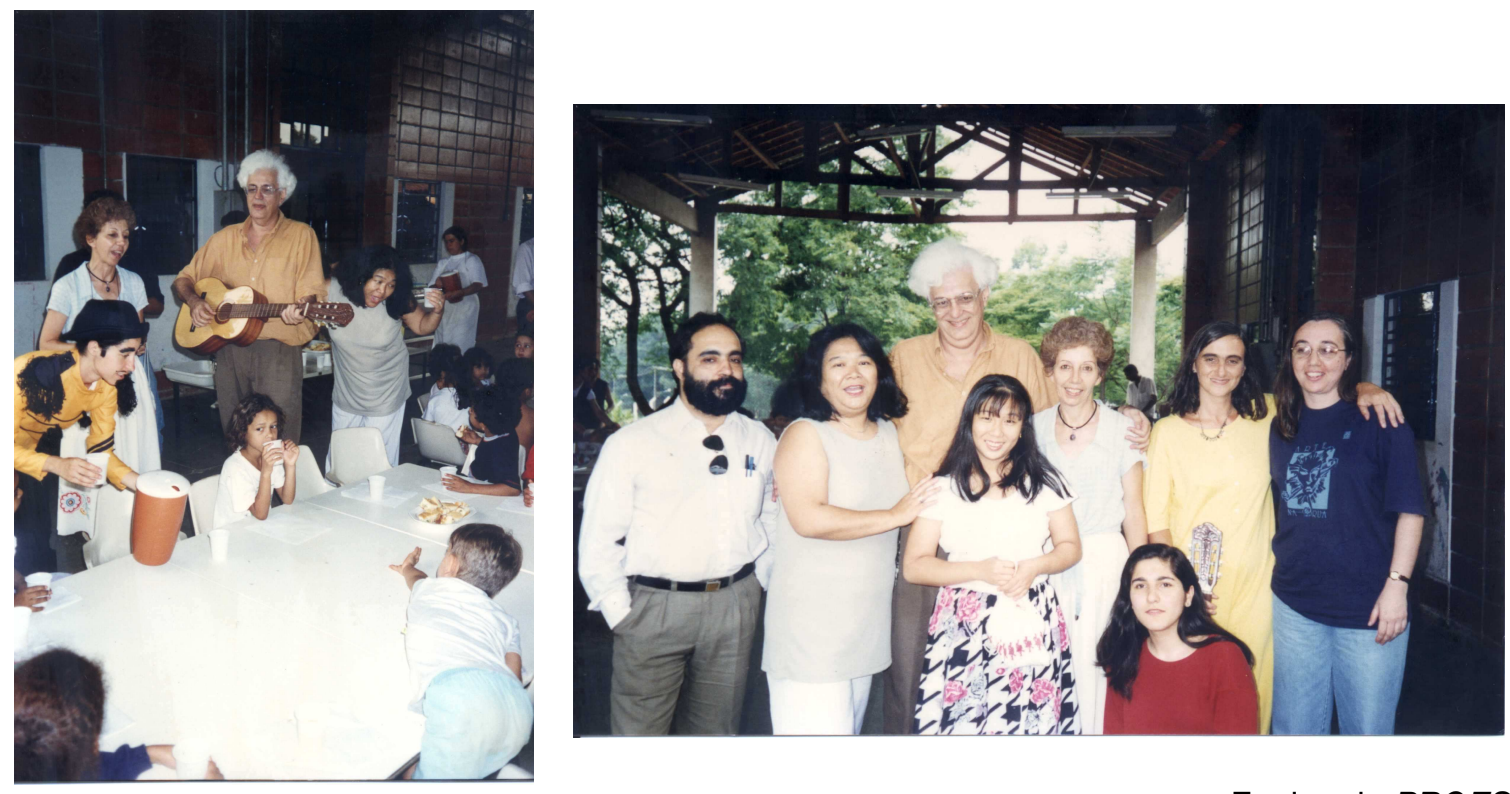

Equipe do PROESI

No mês de outubro de 2001, as crianças do Pré foram visitar uma outra escola de Ensino Fundamental e tiveram a oportunidade de conhecer a biblioteca. A convite da bibliotecária, as crianças se sentaram nas cadeiras, com carteiras organizadas em círculo, para ouvir uma história intitulada "A Galinha Ruiva". Segundo relato de uma das educadoras da Creche/Pré Escola Oeste que estava presente, a bibliotecária encantou o grupo contando a história, mas as crianças estranharam o ambiente, quando encontraram as carteiras na biblioteca. Depois, foi proposta uma atividade para as crianças: pintarem à luz da história contada. Uma das educadoras, indignada com a proposta, trouxe-me a atividade oferecida. Era uma folha mimeografada com os personagens da história "A Galinha Ruiva" para as crianças colorirem e algumas perguntas sobre a narrativa: 

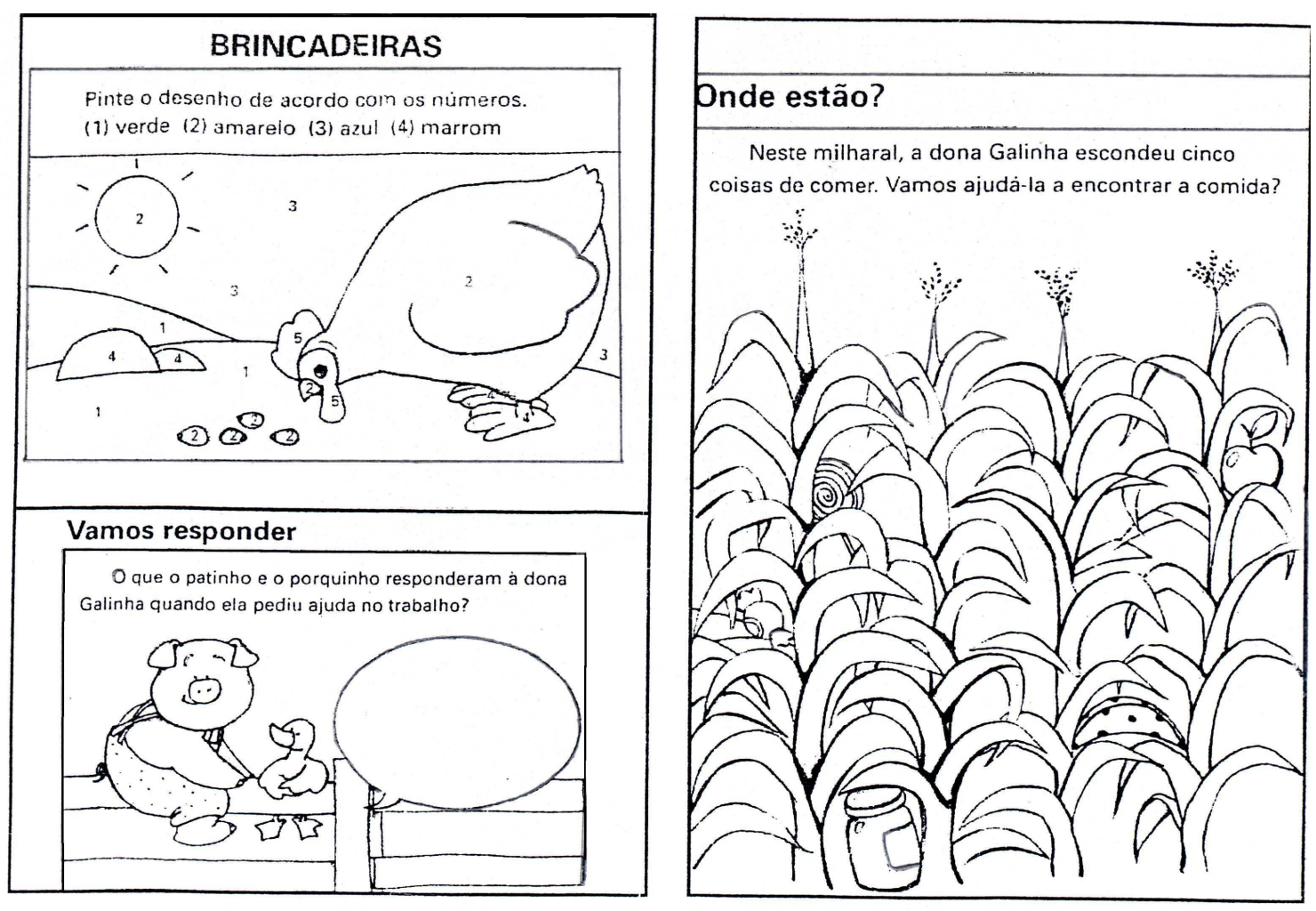

Figura 2

Esse tipo de proposta denuncia que essa escola, especialmente em relação ao uso da biblioteca, ainda está preocupada em avaliar a capacidade de compreensão das crianças sobre as histórias ouvidas. Além disso, oferece desenhos pré-estabelecidos que impedem as crianças de se expressarem nas várias linguagens, desrespeitando o seu potencial humano. As propostas realizadas na biblioteca escolar devem proporcionar às crianças e aos adultos oportunidades de se apropriarem e, também, produzirem cultura.

Estas foram situações marcantes, em que as crianças evidenciaram o significado da Oficina de Informação. Por isso, ela se manteve ativa, acima de quaisquer dificuldades, seja material, seja nas relações entre os adultos.

No ano de 1996, houve necessidade de se sistematizar algumas reuniões com as equipes (Creche/Pré Escola Oeste e PROESI) que trabalhavam diretamente no projeto, com o objetivo de integrar cada vez mais a Oficina de Informação à 
proposta pedagógica. Dependendo da pauta do dia, o grupo convidava o Professor Edmir e Marie Claire para fazerem parte das reflexões.

Quando as crianças iniciaram os empréstimos para casa, as bolsistas do PROESI verificaram que alguns livros voltavam em mau estado. Então, em reunião, o grupo levantou algumas hipóteses sobre essa questão, dentre elas a seguinte: as crianças levavam os livros para casa nas próprias mochilas com roupas, às vezes até os dobravam para caber no espaço. Essa forma de acondicionar os livros para transportá-los não propiciava uma boa preservação.

Diante desses problemas, o grupo teve algumas idéias. Cada criança teria uma pasta de cartolina, confeccionada pelas bolsistas. Depois, o grupo de crianças poderia marcá-las com um lindo desenho realizado na Oficina de Informação. Resolveu-se, então, concretizar essa idéia, mas na prática, o grupo pôde constatar que os livros ainda voltavam amassados e o pior: com o uso, as pastas ficavam sujas, com aspecto desagradável. Isto feria alguns princípios estéticos propostos pela própria equipe do PROESI. Para manter as pastas em bom estado, era necessário arrumá-las, ou até mesmo confeccionar outras, o que demandava um certo tempo e desconfigurava o papel das bolsistas. Então, o grupo pensou em sacolas de pano, pois a durabilidade seria bem maior, além de ter uma alça para que as crianças pudessem levá-las confortavelmente, evitando o uso da mochila.

A equipe do PROESI providenciou panos coloridos (doação que o Prof. Edmir Perrotti conseguiu). Recorrendo ao meu caderno de registro, verifiquei que a Dona Cleide (na época cozinheira da Creche) havia confeccionado, aproximadamente, 34 sacolinhas, que foram entregues somente para dois grupos: G2 e G3 (crianças entre 2 e 4 anos) em caráter de experiência. As sacolas coloridas ficaram tão lindas! Achei que não retornariam mais à Creche, mas nada disso aconteceu. A experiência deu certo e ampliamos a proposta para o Módulo II (crianças até 6 anos e 11 meses). Até hoje, essa forma de transportar os livros para casa é utilizada e, no último ano das crianças na Creche, elas levam de 
lembrança a sacolinha que as acompanhou um bom período de suas infâncias. Quem sabe, ao olharem ou tocarem na sacola poderão evocar momentos significativos que viveram com essa experiência.

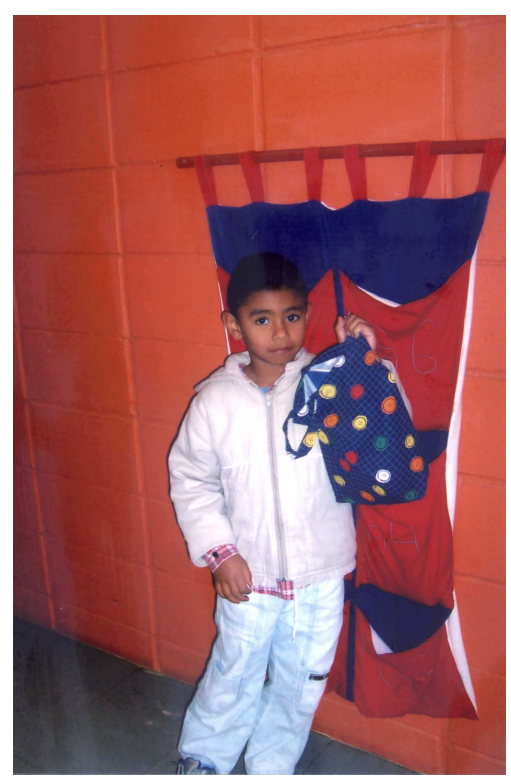

Outra discussão surgiu em relação à devolução dos livros levados para casa, principalmente pelas crianças do Módulo I. As crianças não traziam os livros nos prazos pré-estabelecidos e o grupo levantou algumas hipóteses: uma delas era que crianças da faixa etária de 2 a 3 anos não têm a mesma noção de tempo que os adultos. Além disso, os pais não participaram das discussões sobre a retirada dos livros na Oficina de Informação; portanto, não estavam atentos a essa devolução. Então, as equipes (Creche e PROESI) realizaram dois encontros com os pais do Módulo I, oferecendo dois horários: 12h00 às 13h00 e 17h00 às 18h00. Essa idéia de organizar dois horários de reunião foi para garantir que o maior número de pais participasse das discussões.

Vários pais compareceram à reunião e ficaram encantados com a história que a Toninha contou, emocionaram-se ao relembrarem as histórias ouvidas na infância e queixaram-se da falta de tempo para ler para os filhos. Também disseram que não eram capazes de contar histórias como a Toninha. Nesse momento foi dito que cada pessoa tem uma forma de contar histórias, basta ter emoção, pois a 
técnica pode ser aprendida. Até hoje, as educadoras continuam realizando esse tipo de reunião com os pais do grupo G2; somente depois desse encontro, é que essas crianças iniciam suas escolhas de livros para levar para casa.

Uma outra prática, que foi sendo construída no G2, foi a organização do espaço da sala de cada grupo para receber os livros escolhidos na Oficina de Informação. As educadoras do G2 haviam feito um apontamento bastante relevante em relação ao acondicionamento dos livros na sala. Observaram que os livros ficavam mais no chão do que no trilho afixado na parede, como no projeto da Oficina de Informação (um trilho de cortina afixado invertido, na altura das crianças, servia de apoio para os livros), pois quando as crianças os guardavam, caíam quase todos no chão. O grupo avaliou que esse tipo de suporte não era adequado para aquela faixa etária.

Então, as educadoras pensaram em outra possibilidade. Pintaram, com as crianças, pedaços de cartolinas para afixar na parede, marcando a delimitação do espaço; colocaram um tapete e algumas almofadas no chão e acondicionaram os livros em um baú de plástico. Com a prática, as educadoras constataram que a cartolina não era um material adequado para afixar na parede, pois ficava danificado rapidamente e o baú de plástico, também, não fora uma boa idéia, já que muitas vezes encontravam roupas e brinquedos dentro dele.

As educadoras, então, inspiraram-se no painel de bolsões localizado no saguão da Creche/Pré Escola Oeste para substituir o baú. O grupo pensou em manter uma das características do trilho, que era a possibilidade de as crianças contemplarem as capas dos livros e, por isso, colocaram um visor de plástico fixado no painel para que as crianças pudessem vê-los. Resolveram também, confeccionar uma delimitação aérea (uma tenda) para tornar o ambiente mais gostoso, aconchegante e acolhedor. A delimitação de um espaço na sala para receber os livros da Oficina de Informação foi mantida e, até hoje, cada educador, junto com o seu grupo, cria um ambiente gostoso. 

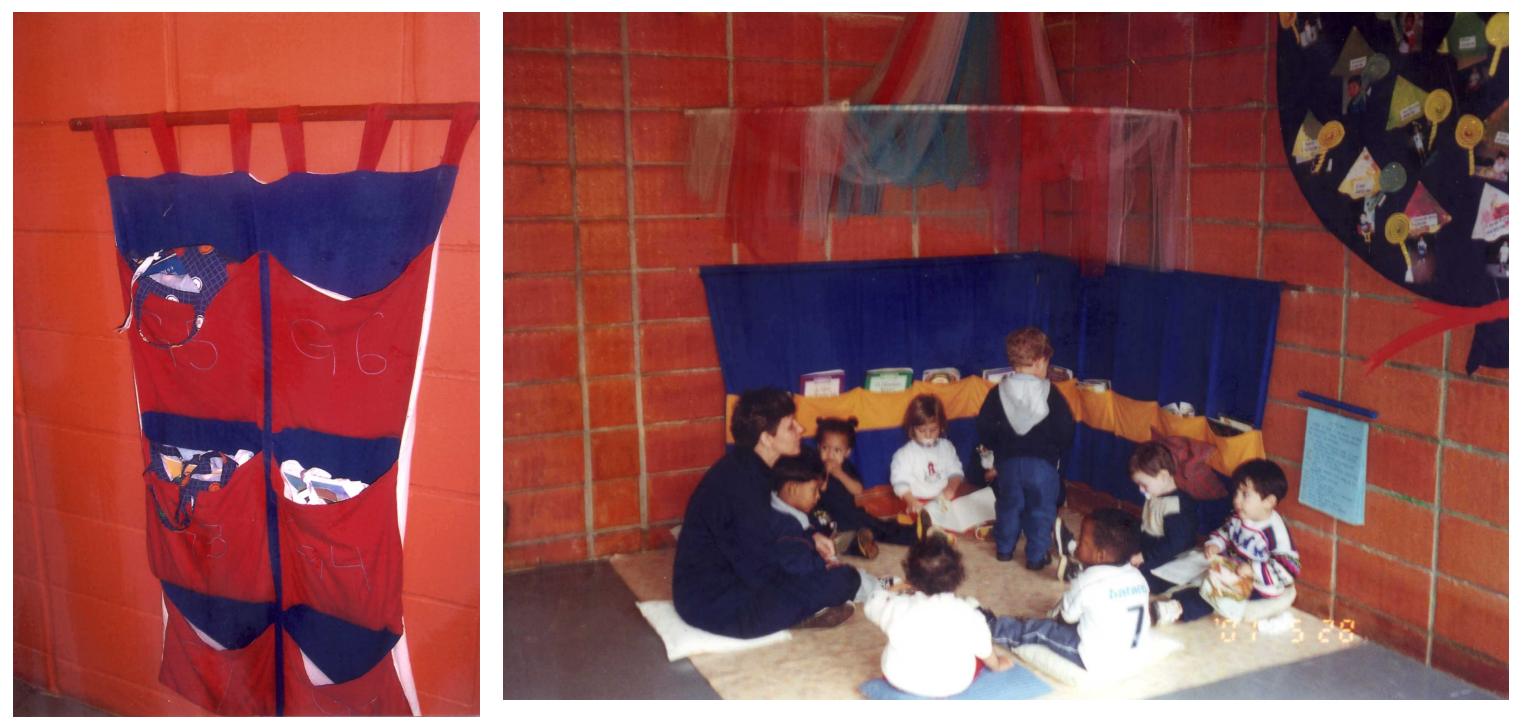

Ao término do ano, os materiais confeccionados em um grupo acompanham as crianças em seu próximo grupo. As educadoras vão reformando os materiais de acordo com o seu estado ou, até mesmo, construindo outros. Com essa prática, a Creche passou a reconhecer a importância de se respeitar e valorizar o investimento realizado pelas crianças e educadoras nos anos anteriores. Essa reflexão não foi nada fácil, quando constatamos que, muitas vezes, reproduzimos ações da própria sociedade, desvalorizando trabalhos de qualidade realizados em gestões anteriores, somente porque foram concebidos por um determinado partido político.

Um dos caminhos possíveis para as crianças de Educação Infantil construírem relações significativas com objetos de conhecimento, como o livro, é a possibilidade de manuseá-los constantemente. Essa interação propicia, mesmo não lendo convencionalmente, a oportunidade de realizar suas próprias leituras a partir dos indícios que o livro oferece, como as ilustrações. No berçário da Creche/Pré Escola Oeste também há um pequeno acervo de livros que as educadoras retiram da Oficina de Informação. No início, os livros de capa e miolo mole tinham uma durabilidade bastante curta, já que os bebês os rasgavam rapidamente. 
O desafio estava posto para as equipes. Se, por um lado, a Creche acreditava que as crianças pequenas poderiam construir uma relação carregada de significados com os livros, por outro, teria que garantir materiais resistentes para suportar os toques, as babas, as disputas, etc.

Entre a concepção que garantia o livre acesso aos livros e a realidade de aprendizado de manuseio por crianças muito pequenas, a Creche optou por organizar a biblioteca no berçário com diferentes possibilidades de acesso aos livros: uma delas garantir uma biblioteca permanente com livros de plásticos, de pano e de papelão aos quais as crianças têm livre acesso, a outra uma caixinha com livros somente de papel, escolhidos pelas educadoras na Oficina de Informação. Essa caixinha é mantida longe do alcance das crianças, mas os bebês podem manusear os livros sob a supervisão das educadoras. Essa solução de deixar os livros de capa e miolo duro (papelão) ao alcance das crianças vem dando certo, evitando, assim, que as educadoras controlem as condições de uso dos livros, sob a alegação de que possam vir a ser danificados.
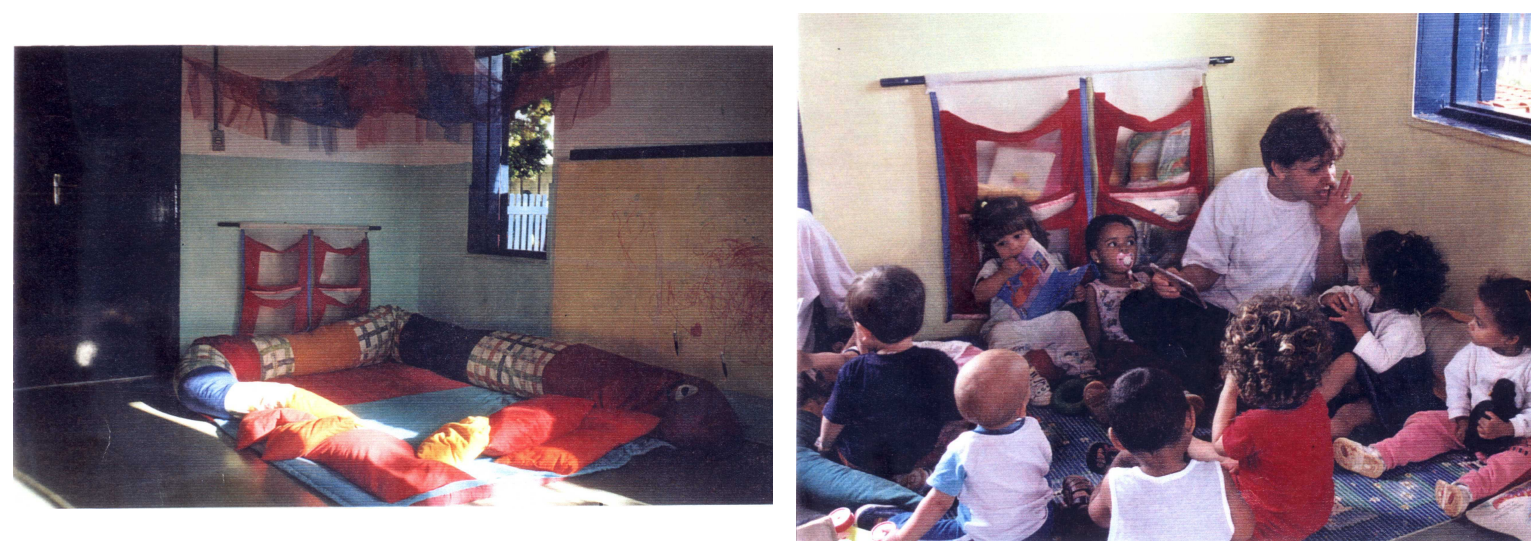

Percebi ao observar as crianças que saem do berçário para o G2, o quanto têm intimidade com os livros. Essa relação ficou nítida em um episódio que ocorreu no G2: a Creche recebeu uma criança nova no G2. Quando ela avistou os bolsões com os livros, aproximou-se, pegou um deles e logo foi rasgando-o. As crianças 
por volta de 2 anos e 5 meses, que já tinham um contato intenso com os livros no berçário, imediatamente correram ao encontro da educadora para mostrar a gravidade da situação.

Em uma das nossas reuniões com o Prof. Edmir Perrotti, a equipe colocou a questão de um menino com 5 anos, filho de uma família cuja mãe não decodificava os códigos alfabéticos e o pai utilizava a escrita somente para assinar seu nome.

Os livros levados para a casa, por esse menino, voltavam rasgados e riscados. Depois de uns 10 livros danificados, resolvi conversar com o pai, para compreender melhor o que se passava e tentar ajudá-los, mas ele sentiu-se constrangido e proibiu a entrada de livros em sua casa. O que fazer diante desse impasse? Nesse momento, o Prof. Edmir fez uma observação bastante relevante com a equipe, afirmando que neste percurso de formação de leitores o mais importante é o sujeito e não o objeto. Assim, o menino continuou a levar os livros para casa, bem como suas irmãs, que também freqüentavam a Creche/Pré Escola Oeste. Depois do 12ำ livro, essa situação nunca mais se repetiu.

No intuito de a Creche se apropriar da Oficina de Informação, pensou-se na possibilidade das volantes Fátima e Conceição (educadoras que não têm um grupo fixo) desenvolverem um trabalho integrado com a Oficina de Informação. De acordo com os meus registros, Fátima, a volante do Módulo I, ficaria responsável pela organização do espaço para receber os livros na sala, escolhidos pelas crianças. Ela, então, resolveu confeccionar diversas almofadas com restos de lençóis brancos e convidou as crianças para pintá-las com anilina. As almofadas ficaram lindas! Mas Fátima somente entregou as almofadas para os grupos do Módulo I e saiu da Creche para trabalhar em outro local. Já a Conceição queria contar histórias na Oficina de Informação. Para isso, resolveu preparar alguns materiais, entre eles uma caixa que intitulou de "Macabra", pois as crianças pediam para que contasse histórias de terror. Organizou diversos materiais 
comprados e confeccionados tais como: aranha, teias, morcego, etc. Conceição somente conseguiu contar histórias para o G4 na Oficina de Informação, pois teve que substituir uma licença médica de uma educadora do berçário. A Creche avaliou que a natureza da função da volante não possibilitava atuação na Oficina de Informação, pois não conseguiam concretizar seus projetos.

Algumas reuniões de módulo foram coordenadas pela equipe do PROESI, em especial pela Toninha, que refletiu com o grupo sobre a arte de contar histórias.

Um marco importante na história da Creche/Pré Escola Oeste com a Oficina de Informação foi a criação do Ofinforma, um boletim informativo mensal sobre o desenvolvimento dos trabalhos realizados na Creche e também na Oficina de Informação. Esse trabalho, feito por uma das bolsistas do PROESI, sob supervisão do coordenador Professor Dr. Edmir Perrotti, era apresentado por um simpático personagem - o Ofin. Ao ler alguns boletins pude constatar a variedade de informações sobre a Creche, abrangendo desde notícias sobre funcionários até trabalhos realizados pelas educadoras e crianças. Os profissionais da limpeza, da cozinha davam depoimentos ou contavam novidades sobre suas vidas. As educadoras participavam relatando sobre os projetos e as crianças desenhavam para ilustrar o boletim. Esse trabalho se foi junto com os bolsistas do PROESI no ano de 2000. A Creche não investiu nesse projeto, talvez por falta de competência ou mesmo a compreensão do seu papel, ou dificuldades para realizá-lo, uma vez que as políticas instituicionais da Universidade, ainda não o assimilaram também. 


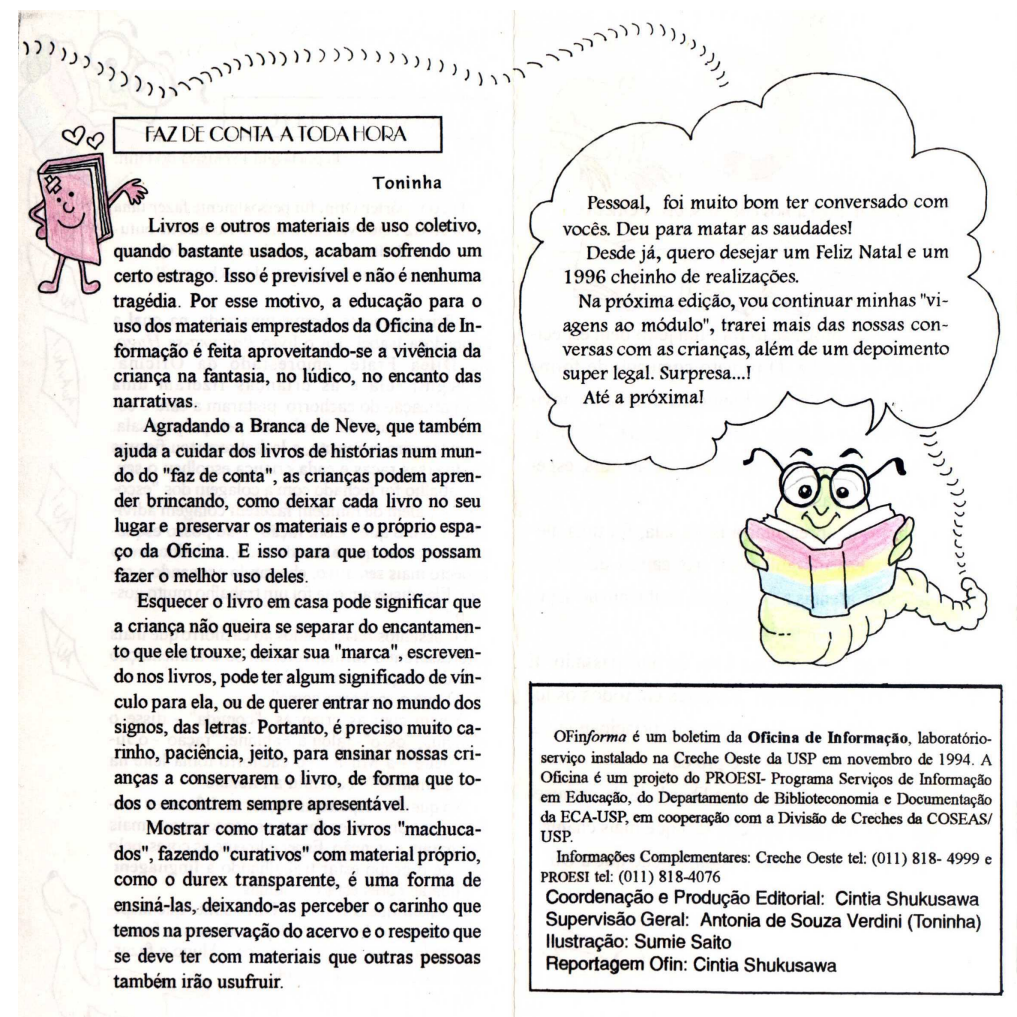

Figura 3 - Ofinforma (Frente )

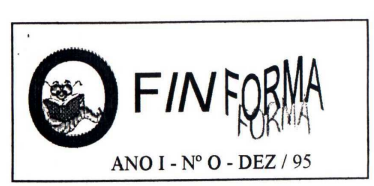

Olá, amigos! Tudo bem com vocês? Eu ja estava com saudades de uma boa conversal Neste boletim, podemos conversar e refletir sobre um monte de coisas. Querem um exem plo? O G2 vai nos falar um pouco do que aprenderam sobre ocachorr. Ih!... mastem muito mais.

\section{LER PARA CRER}

Para começar, a Toninha já vai contar o que Para começar, a Toninha ja vai contar o que
achou do Picasso. Que tal embarcar na sugestão dela? Fala Toninhal

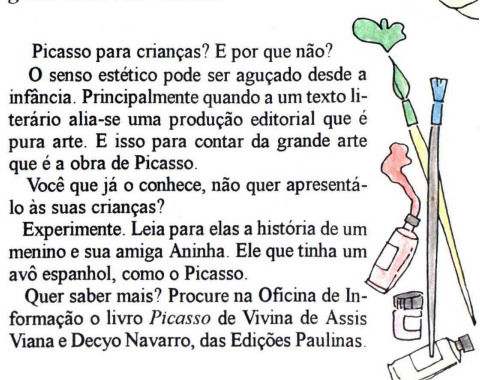
Viana e Decyo Navarro, das Edições Paulinas

\subsection{3 - Mudanças na Oficina de Informação}

No ano de 1997, a Oficina de Informação ganhou móveis novos projetados pela Prof $^{\underline{a}}$ Cibele Haddad Taralli, da FAU/USP e membros da equipe do PROESI.

Uma grande estante acompanhada por uma mesa para acondicionar materiais e um computador. Mais duas estantes móveis foram confeccionadas, uma para colocar aparelho de som e televisão com vídeo, e outra com prateleiras e pequenas gavetas para dispor as fotos das crianças e funcionários. 

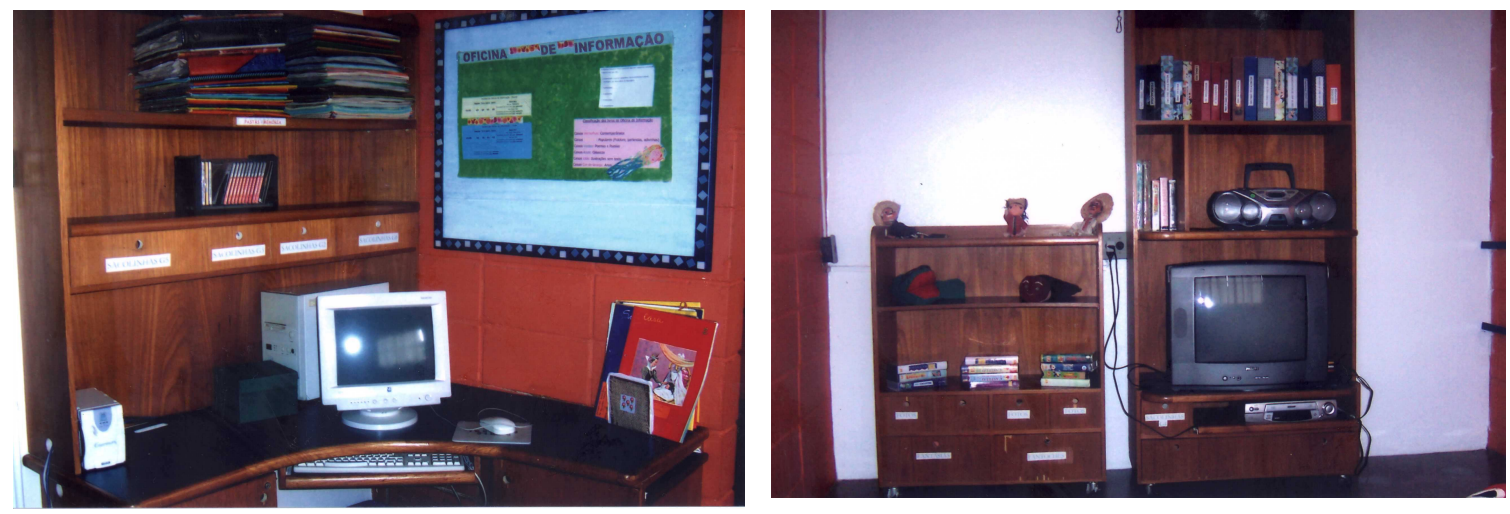

Os livros também ganharam um outro "abrigo", pequenas caixas de madeira assentadas em um suporte plano com grandes rodas, criando a idéia de pequenos vagões de trem. Os forros das almofadas foram trocados. O quadro de avisos acompanhava o design dos móveis.
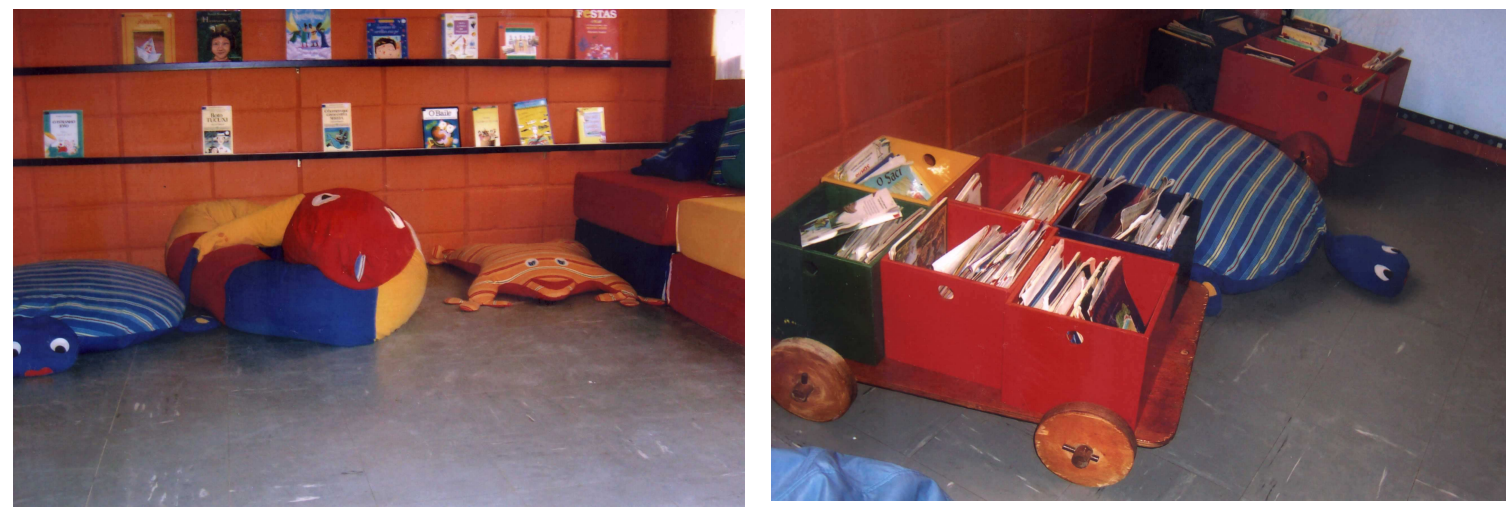

Uma grande festa foi preparada para esse dia! O estacionamento da Creche foi transformado em um pequeno auditório, cadeiras organizadas e uma mesa composta por representantes da parceria: Marie Claire, diretora da Creche/ Pré Escola; Maria Clotilde Magaldi, diretora da Divisão de Creches; professor Edmir Perrotti, coordenador do projeto; professor Max Butlen representante do Institut Universitaire de Formation de Maîtres de I'Académie de Versailles - França, Prof. Emmnnuel Fräisse atual diretor do Instituto National de Recherche Pedagogique, de Paris. Dentre os presentes, a Professora Tizuko, da Faculdade de Educação, da USP, os funcionários da Creche e da Divisão de Creches, bolsistas do 
PROESI, professores do Departamento de Biblioteconomia e amigos. Junto com as crianças, no pátio da Creche estava a escritora e ilustradora Eva Furnari, desenhando e conversando sobre seu processo de criação. Dentre os vários discursos do dia, emocionei-me com o da Claire, que começou assim:

\begin{abstract}
Abertura da nova Oficina de Informação
Para nós da Creche Oeste é muito estimulante e prazeroso estar aqui hoje inaugurando este novo momento da Oficina de Informação. Desde 94 esta parceria conta com o envolvimento de todos que dela participam: existe muita vontade e seriedade neste fazer, ao lado do cuidado e respeito mútuos. Podemos dizer que este cuidado e este respeito permitem que Creche e pesquisadores se escutem e se transformem através desta experiência, na qual conceitos e rotinas se movem, gerando novas idéias e propostas. Sabemos bem que o dia-a-dia promove nas crianças uma intimidade com o universo cultural que os materiais da Oficina disponibilizam para elas. Mas o que é intimidade? Entendemos que a intimidade se dá num contado livre e intenso e é o que vai nos permitir desenvolver o gosto por alguma coisa, fazer escolhas, descobertas $e$ construir assim também nossa própria identidade. Esta intimidade é fundamental, e promover nas crianças a vontade de buscar mais coisas ou até mesmo, como é freqüente, buscar de novo as mesmas histórias e situações. As crianças pedem bis, e às vezes não se cansam de ouvir as mesmas histórias, $O$ "diariamente" é muito diferente do "de vez em quando" quando se fala em formação. Temos visto as crianças criarem uma relação gostosa com o livro de história e de pesquisa, com filmes, vídeos, etc. $O$ respeito à criança está presente, e não é só no discurso não. E nas situações de dificuldade isto tem que estar bem claro. $O$ que fazer quando uma criança rasga um livro? Ou com um pai que chega dizendo que não vai mais levar livros para casa porque o filho perdeu o último que levou? Temos claro que a criança é mais importante que os livros e quaisquer outros materiais, e é nela que vamos nos deter para colocar os limites, entendê-la e educá-la para a vida em sociedade. Não somos guarda-livros. Somos educadores de crianças pequenas, $e$ investimos para incentivar uma relação gostosa entre elas e os objetos de conhecimento. A Oficina desde sempre trouxe isto muito claro: cuidado com ambiente e com tudo que é oferecido para as crianças sem se deter em ficar citando regras de bom comportamento, mas que partindo de uma relação corajosa de confiança e respeito tem recebido por parte de todos o mesmo tratamento.

E não são só as crianças que valorizam e usufruem da Oficina, percebemos isto com clareza também nos pais e em todos os funcionários da Creche. Não estou exagerando quando digo todos: educadores, equipes da limpeza e cozinha, técnicos de enfermagem, nutrição $e$ administrativo, vigias e coordenação. Outro dia, conversando com as funcionárias da limpeza e cozinha elas não tinham dúvidas sobre a importância da Oficina: "É um trabalho ótimo, especial! As crianças se interessam pela leitura!", "As vezes nós também lemos na hora do almoço".
\end{abstract}


Há um ponto em que Creche e Oficina se dão as mãos firmemente: não podemos perder de vista o lúdico e tudo que incentiva a imaginação.

Vivemos num mundo carente de boas imagens, no qual a mídia veicula todo o tempo informações rápidas, pouco desenvolvidas e que caem facilmente em estereótipos e preconceitos. E cada vez mais cedo se cobra das crianças que aprendem coisas: ler, escrever, contar, etc, retirando de tudo o prazer de conhecer.

Não nos ocupamos de impor quaisquer conhecimentos às crianças. Temos certeza que elas aprendem, principalmente se puderam ser respeitadas e puderem desfrutar dos conhecimentos que adquirirem.

\section{Uma das educadoras (Mariana) também fez um discurso sobre o significado da Oficina de Informação para os bebês. Como fruto dessa fala, um texto foi organizado para ser publicado no Ofinforma, mas isso não foi feito, por algum imprevisto. O texto dizia:}

Era uma vez um grupo de crianças, crianças bem pequenas que ainda nem andavam, esse grupo era um berçário que ficava numa casinha cheia de objetos coloridos como almofadas, fantoches e livros.

Livros? Em um berçário?

Sim, livros, no começo eram livros de pano, só com figuras e de plástico com algumas frases curtas para que brincassem na banheira, mas depois fomos percebendo o interesse delas pelos livros e construimos alguns que eram de figuras de qualidade coladas em uma folha sulfite e coloridas dentro de um plástico, mas ainda não bastava, as crianças queriam mais. Passamos a utilizar o espaço da Oficina de Informação, pensamos que seria muito difícil, pois ficava longe (A Creche tem três prédios e a Oficina fica no mezanino, no prédio da administração) para ir com os bebês e as escadas? Seria muito complicado para subir com as crianças. Que desafio!

Esse percurso do berçário até a Oficina de Informação era motivo de alegria das crianças que acenavam a todos e sorriam e dos funcionários da creche que inclusive nos ajudavam a subir com os menores no colo, $e$ os maiores subiam de gatinhos...

Mas o que um berçário faria neste espaço? Rasgariam todos os livros! Não, não rasgaram!

Retiravam os livros das caixas coloridas e brincavam com elas, pegavam os livros e folheavam, nos pediam para contar as histórias, viam fotos, exploravam todo o espaço!

Hoje, no G2 (crianças de 2 anos) o entusiasmo e a alegria de visitar a Oficina de Informação não é menor. Principalmente depois que foi reorganizada na sua mobília, decoração e acervo.

O espaço ficou mais rico, as crianças cresceram, a cada visita novas descobertas aconteciam, como o uso dos fantoches, das histórias em CDs, da TV e do vídeo, onde as crianças não só assistem a desenhos, mas a filmagens delas próprias em momentos diversos da rotina. Sugerimos a escolha de livros da caixa azul e da caixa rosa, são mais adequados a 
essa faixa etária, as crianças manuseiam, olham a capa, as figuras, as cores e pegam o de seu interesse com autonomia.

O grupo construiu, estabeleceu uma relação com os livros que se expressa a partir de seu interesse e desejo de visitar a Oficina de Informação diariamente.

O grupo se apropriou deste espaço.

Mariana/97

Nesse dia, tive a dimensão da importância desse projeto para a Creche/Pré Escola Oeste e para a Educação em geral.

Encontrei em uma das pastas da Creche alguns bilhetes produzidos no ano de 1998, em especial um que me fez relembrar a ida de 3 educadoras a França.

Atenção Educadores

Urgente

O professor Edmir vai acompanhar um grupo em visita a Paris, na última semana de março/98. A visita terá duração de 1 semana e será custeada pelos interessados e sairá em torno de $R \$ 2000,00$ ( $R \$ 800,00$ despesas mais $R \$ 1.200,00$ passagem). A passagem pode ser paga em $10 X$.

Avaliamos que, se o quadro estiver completo, dois educadores poderão acompanhar o grupo. Por isso, quem estiver interessado, nos procure no máximo até $4^{o}$ feira, porque precisamos confirmar com o Prof. Edmir.

Pensem bem

Claire e Rose

Nos registros constam que 7 educadoras se inscreveram (Mariana, Cristina, Sônia, Valéria, Suzana, Ana Elisa e Roberta). Eu e Claire havíamos combinado que, se muitas pessoas se interessassem, teríamos que fazer um sorteio. Quando chegou a época de fechar o contrato, somente 3 educadoras confirmaram (Mariana, Suzana e Cristina). Assim, não houve necessidade de realizar o sorteio. 
Este estágio tinha como objetivo o conhecimento de bibliotecas e serviços de informação, (bibliotecas escolares e públicas, museus, feira do livro, etc). O grupo pôde conhecer várias instituições educativas, bem como o sistema educacional francês e as políticas acerca da educação e da leitura.

Quando as educadoras voltaram de Paris, a coordenação abriu um espaço na formação continuada para que contassem sobre o estágio. Dentre os vários assuntos abordados, uma das educadoras contou-nos sobre o projeto desenvolvido em uma das bibliotecas da cidade de Eaubonne que tinha um espaço físico amplo, claro e acolhedor. Esse espaço era dividido em vários ambientes, um deles destinado para a "hora do conto", outro para oficinas. O marco deste espaço era o trabalho com as "mães crecheiras" (mulheres que cuidam de crianças nas suas próprias casas enquanto suas mães trabalham) que, num determinado momento do dia, levavam as crianças à biblioteca para ouvirem histórias e escolherem livros para casa.

\subsection{4 - Assumindo a Oficina de Informação}

Este tempo foi marcado pela mudança do coordenador do PROESI na Creche/Pré Escola Oeste e pela introdução de bolsistas que tinham um vínculo específico com as Creches da USP.

O coordenador do "laboratório" da Oficina de Informação passou a ser o Professor Dr. Waldomiro Vergueiro, que também pertencia à equipe do PROESI. Após diversas avaliações sobre a importância da apropriação do projeto pela instituição, a equipe do PROESI resolveu oferecer as bolsas mantidas pelo CNPq para funcionárias que tivessem vínculos com a Creche. A primeira bolsa foi oferecida, mas a Creche/Pré Escola não tinha nenhuma educadora que se enquadrasse dentro dos requisitos exigidos. Então, a Creche/Pré Escola Oeste requisitou uma educadora da Creche/Pré Escola Central, pertencente à mesma rede, no mês de 
fevereiro do ano 1999, no período da tarde e uma educadora da própria instituição pôde, também, tornar-se bolsista.

A bolsista que coordenava o projeto na Creche passou a supervisionar as novas bolsistas e o trabalho da Oficina começou a ter outras marcas, garantindo sempre a concepção do projeto.

Eva, a bolsista do período da manhã, estabeleceu uma parceria bastante interessante com as educadoras da Creche/Pré Escola Oeste, sempre convidada a participar de alguns projetos de trabalho desenvolvidos pelos grupos e outras práticas que já faziam parte da rotina. Durante o momento de ateliê (propostas diversas e simultâneas), que acontecia das $7 \mathrm{~h}$ às 8 h30min, Eva convidava algumas crianças para jogar no computador da Oficina de Informação. As crianças interessadas pela proposta montavam uma escala para essas participações.

A bolsista do período da tarde, Adriana, como também era educadora da Creche/Pré Escola Oeste, deu bastante ênfase ao trabalho de extensão da Oficina de Informação, iniciando com a organização de uma sala intitulada "Sala das Educadoras", que continha livros de pesquisas e literatura Infantil, documentários em vídeos e cd's, escaninhos para acondicionar trabalhos em andamentos. Esse espaço era almejado pelas educadoras e funcionários que não tinham um espaço adequado com mesas, para que pudessem confeccionar materiais e elaborar planejamentos. O espaço tem sido bem aproveitado até hoje pelas educadoras e algumas até chegam antes do horário de trabalho para realizarem seus planejamentos e pesquisas.

Nas visitas que a Creche/Pré Escola Oeste recebe de outras instituições educativas, os professores e coordenadores, ao contemplarem o espaço da Sala das Educadoras, admiram o local, desejando ter algo assim, algum dia. Um espaço reconhecido e cuidado inspira respeito aos protagonistas que atuam na instituição. 


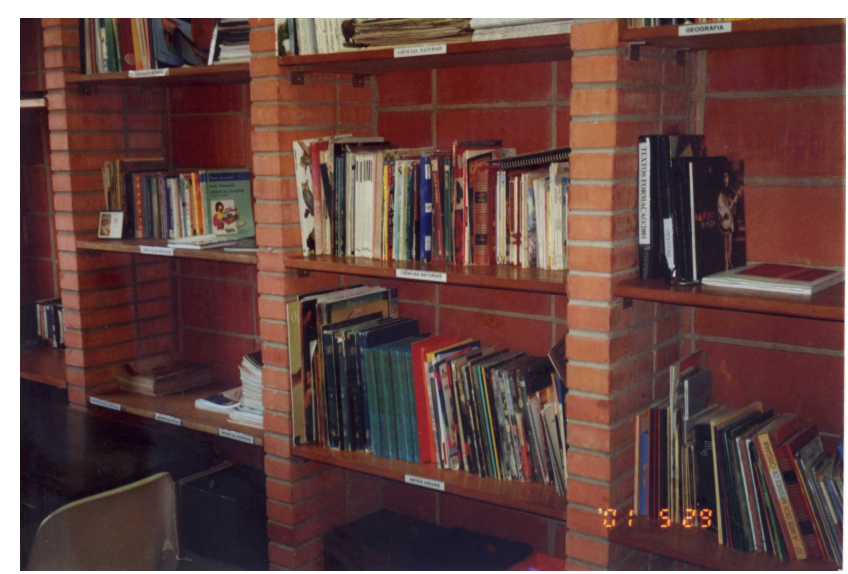

No refeitório dos funcionários, a bolsista também organizou um painel, com expositor de plástico para divulgação de livros que, após uma semana, estariam disponíveis na sala dos educadores para empréstimos. Outra ação importante foi retirar da sala da coordenação os livros de pesquisas e técnicos, revistas especializadas e literatura em geral, para organizar o acervo na sala dos educadores.

Após a constatação de que as crianças maiores não sabiam ou não se lembravam dos contos de fadas (pois com o tempo de uso esses livros foram danificados) criamos uma bibliografia básica para os educadores usarem no decorrer do ano.

Foram adquiridos dois exemplares de cada livro da bibliografia básica, um para ficar na Sala dos Educadores e o outro na Oficina. Assim, as crianças teriam, também, a possibilidade de levar os livros para casa.

Foi ampliado o acervo de fitas de vídeo, comprada a coleção completa do "Castelo Ratimbum", sendo estabelecido que seria guardada na "Sala das Educadoras", para ser usada somente na Creche. Com o passar o tempo, a Creche percebeu que, novamente, predominava a concepção de conservação dos materiais. Justamente as fitas de vídeo, que as crianças adoravam escolher, subindo à Oficina de Informação com seus pais, Ihes seriam negadas para empréstimo? 
Ficou resolvido que as fitas seriam guardadas na Oficina de Informação e as crianças teriam a possibilidade de levá-las para casa (o que passou a ocorrer quase todos os dias).

\subsection{5 - A Creche/Pré Escola Oeste responsabilizando-se integralmente pela Oficina de Informação}

O contrato das duas bolsistas da equipe do PROESI chegou ao fim, e a Creche/Pré Escola Oeste assumiu integralmente o projeto da Oficina de Informação. A Divisão de Creches conquistou, no mês de maio de 2001, uma vaga para estagiária-educadora, que foi preenchida por uma estudante da FEUSP (Faculdade de Educação da Universidade de São Paulo), com um contrato de 6 horas diárias para trabalhar na Oficina de Informação.

A última bolsista do PROESI, antes de findar o seu contrato, desenvolveu o trabalho de formação em serviço da nova estagiária-educadora, detalhando a rotina da Oficina de Informação, relatando sobre as propostas realizadas e revelando a concepção que embasava o trabalho.

Assim, em agosto desse ano, a estagiária-educadora assumiu a Oficina de Informação sob a orientação da coordenação da Creche/Pré Escola Oeste, com objetivo de continuar as práticas existentes na Oficina de Informação e criar outras, principalmente, ampliando o trabalho para a comunidade. Algumas ações foram planejadas, tais como:

- criar um painel situado no saguão da Creche para a comunidade, divulgando eventos culturais da cidade de São Paulo;

- destacar um artista do mês, na Oficina de Informação, a partir da sugestões dos funcionários, crianças e pais; 
- confeccionar um livro de receitas constituintes do cardápio da Creche, juntamente com a equipe da cozinha;

Além disso, também era necessário ampliar e repor o acervo de livros, renovar os panos das almofadas e conseguir a reposição de um aparelho de vídeo cassete para a Oficina de Informação.

Com relação à ampliação e reposição do acervo da Oficina de Informação, a Associação de Pais e Funcionários, sensibilizada com o desgaste dos livros e acreditando na importância da literatura Infantil na formação de leitores críticos e criativos, enviou pedidos de doação (com uma lista anexa de exemplares danificados pelo uso) para a Associação de Professores da USP.

Após alguns meses, a Creche ganhou 60 livros, dentre os que havia sugerido na lista.

Sabemos, porém, que é necessário encontrar outros caminhos para garantir um acervo de qualidade nos vários aspectos, tanto literário quanto na reposição e ampliação do acervo. Uma das competências importantes na formação dos leitores é o aprendizado do cuidado com os livros que pertencem à comunidade da Creche. Assim, é uma grande contradição a Creche dispor de exemplares danificados para o grupo escolher e dialogar com esses objetos de conhecimento, em estado deteriorado.

Após 7 anos de uso intenso, o aparelho de vídeo não resistiu, quebrando sistematicamente, prejudicando, inclusive, o trabalho com as crianças. Depois de vários consertos sem sucessos, a Divisão de Creches enviou um aparelho de televisão e um vídeo-cassete novos.

Para propiciar um espaço prazeroso e aconchegante, as almofadas de pano com formato de bicho são fundamentais, mas para mantê-las com um bom aspecto há 
necessidade de trocar as capas pelo menos um vez ao ano. Assim, a Creche/Pré Escola Oeste solicitou à Divisão de Creches os tecidos e a confecção das almofadas foi financiada pela Associação de Pais e Funcionários.

\subsection{6 - Pastas-memória : exemplo de resultados}

A Creche/Pré Escola Oeste vem, durante alguns anos, desenvolvendo diversos projetos com as crianças. No final de cada trabalho, crianças e educadoras organizam uma grande exposição no saguão da Creche, demonstrando, a partir das várias linguagens expressivas, o percurso do projeto. Assim, toda a comunidade tem a possibilidade de contemplar as produções realizadas pelas crianças. Apesar disso, faltava garantir a "memória concreta" desses projetos, após a exposição. Embora tivéssemos a Oficina de Informação, espaço propício para democratização das documentações e das informações, alguns materiais ainda permaneciam guardados na sala da coordenação, sob a justificativa de que era preciso preservá-los.

Os registros que permaneciam na Creche/Pré Escola sobre os projetos de trabalho eram cópias de relatórios destinados aos pais e fotos de alguns momentos, organizados em álbuns. Com o passar do tempo, sentimos a necessidade de documentar os projetos, pois percebemos que não havia registros da história do processo dos trabalhos das crianças.

Surgiu a idéia de organizarmos as pastas-memória, contendo fotos, legendas, autores, co-autores e até mesmo as ilustrações das crianças. Assim, além das lembranças, a Creche teria registros concretos que serviriam de referência às educadoras de outros grupos, à divulgação do trabalho e à possibilidade de as crianças e funcionários evocarem os momentos significativos vividos. Enfim, a memória dos protagonistas que atuam e atuaram na Creche Oeste estaria registrada nas pastas. 
As primeiras pastas-memória foram confeccionadas e apresentadas em uma das formações continuadas ${ }^{22}$ para todos os funcionários e, inclusive, para o Professor Dr. Waldomiro, do Departamento de Biblioteconomia que, no dia, estava fazendo um trabalho na Creche/Pré Escola Oeste. O professor indagou: "Por que as pastas-memória não ficam na Oficina de Informação e sim na sala da coordenação?" A resposta foi dada por mim: "Não podemos deixar as pastasmemória na Oficina pois poderão ser danificadas." Essa pergunta foi fundamental para que a Creche/Pré Escola tomasse consciência da grande contradição que estava realizando, ao aprisionar os materiais em nome da conservação, impedindo o acesso à consulta. Já existia na Oficina o trabalho de memória, com a gaveta e painel de fotos das crianças, que ali ficavam e eram usadas para consultas das próprias crianças ou dos educadores. Poderíamos ampliar este trabalho fundamental.

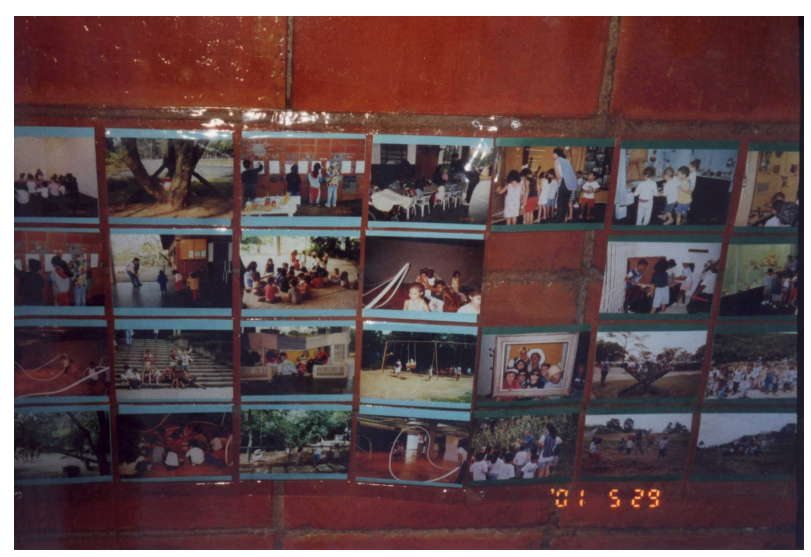

Pude me rever diante dessa postura e concordar que as pastas - memória teriam que estar num local para toda a comunidade da Creche ter acesso. Resolvemos, então, organizar uma grande exposição das pastas-memória no saguão do prédio, espaço de grande circulação dos adultos e crianças, antes de levá-las para a Oficina de Informação. Essa prática de divulgar os materiais antes de colocar no acervo da Oficina de Informação foi aprendida com a equipe do PROESI. Durante

\footnotetext{
22 Formação Continuada: paradas mensais em que a Creche/Pré Escola Oeste trabalha sem crianças, discutindo com toda a equipe o trabalho desenvolvido, visando garantir sua qualidade.
} 
a exposição, algumas pessoas, apesar da pressa, não resistiam e sentavam nas almofadas para contemplar as belas imagens. As crianças levavam os pais pelas mãos para mostrar o que haviam feito. Foi um grande sucesso!

$\mathrm{Na}$ interação das pessoas com os materiais, observamos que a falta de tempo as fazia olhar os materiais com uma certa rapidez. Como forma de lidar com essa dificuldade, resolvemos diminuir os textos das legendas nas próximas pastas, considerando que, muitas vezes, a linguagem fotográfica é capaz de dialogar por si só.

As bolsistas reservaram espaço na Oficina de Informação para colocar as pastas, assim todos teriam a possibilidade de dialogar com os registros, desde os pais até os estudantes e profissionais da área que recebemos para conhecer o trabalho. Desta forma, a identidade do grupo vai se constituindo, a partir do momento em que todos se vêem nesse processo dinâmico, representado nas pastas-memória e nos diferentes espaços da Creche/Pré Escola Oeste.

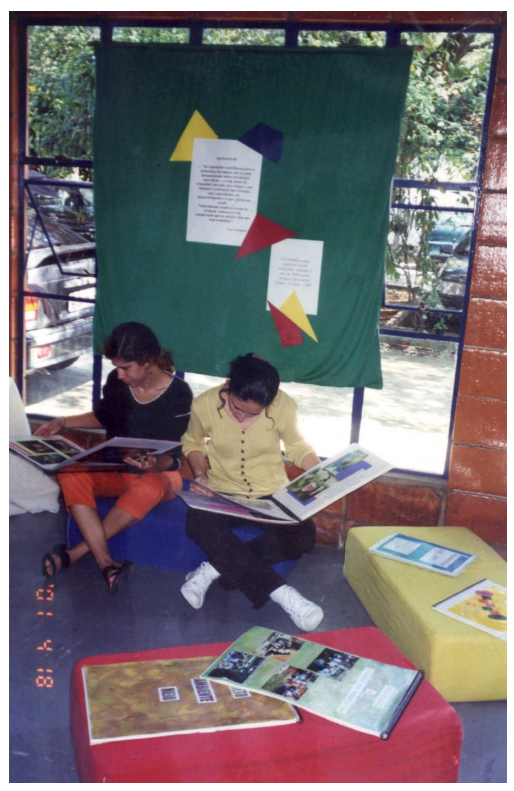

As pastas-memória já foram apresentadas em diversos programas de formação continuada, como instrumento de reflexão, para os professores de Escolas de Educação Infantil da rede municipal de São Paulo e Guarulhos e para estudantes 
dos cursos de Pedagogia da Faculdades de Educação da USP, de Filosofia, Letras e Educação da Mackenzie e Faculdade Associada de Cotia.

\subsection{7 - Ampliação do atendimento}

Um dos objetivos do Projeto da Oficina de Informação era abrir as portas da biblioteca para a comunidade.

Quando a Oficina de Informação foi montada na Creche/Pré Escola Oeste, o campus da Universidade, nos finais de semana, era povoado principalmente pela comunidade do entorno para desfrutar o espaço (brincando, correndo, andando de bicicleta ou mesmo contemplando a paisagem natural do campus). O grupo do PROESI acreditou que havia, ali, uma situação propícia para democratizar a biblioteca. Em um dos finais de semana, a equipe do PROESI fez uma programação para contar histórias ao ar livre, bem defronte da Creche/Pré Escola Central, localizada próxima ao portão principal do campus, convidando as pessoas que circulavam no local para participarem.

Porém, tempos depois, a Universidade de São Paulo, por falta de uma infraestrutura adequada para receber a população, fechou suas portas nos finais de semana. Desta forma, esse caminho foi fechado para ampliação do atendimento na biblioteca.

No ano de 2001, a Creche/Pré Escola Oeste estabeleceu um vínculo com uma instituição chamada Alô-Alô, localizada na favela São Remo, para freqüentar, esporadicamente, a Oficina de Informação, em caráter de experiência. A instituição atendia 50 crianças, divididas em dois períodos. O espaço era uma casa adaptada, que no período noturno oferecia aulas de alfabetização para os adultos da comunidade. 
O contrato estabelecia, a cada quinzena, vindas à Oficina de Informação, sempre às sextas-feiras. As crianças da escola Alô-Alô, além de desfrutarem do ambiente da Oficina de Informação, teriam a possibilidade de escolherem livros para a escola. Acompanhei esse trabalho de várias formas: estabelecendo os contratos com as responsáveis pela escola, organizando o planejamento e avaliando, junto com a educadora da Oficina, observando e registrando a interação das crianças com o ambiente e replanejando os próximos encontros a partir das pistas do grupo.

A primeira visita aconteceu no dia 05 de setembro de 2001. A educadora da Oficina de Informação, Valéria, organizou um passeio pela Creche/Pré Escola e um delicioso lanche (bolo e suco) no pátio. As crianças adoraram o bolo de chocolate que a lactarista da Creche/Pré Escola Oeste havia preparado, e ela fez questão de acompanhar o momento. Depois, foram conhecer os banheiros que, por sinal, acharam lindos. Brincaram nos pátios, tanque de areia, pneus, em especial no play ground. Corriam sem parar, de um lado para o outro; às vezes, me dava a impressão que não conseguiam nem sentir as brincadeiras, de tanta euforia.

Não demorou muito e várias cabeças apareceram do outro lado da janela: era o grupo do Pré, que tentava compreender por que aquelas crianças estavam brincando no espaço deles. A educadora do grupo tentou convidá-los para continuarem na sala, com a Roda de histórias, mas não adiantou, principalmente, porque um dos meninos gritou: "Eu conheço aquelas crianças, elas moram no lugar onde eu também moro".

A educadora da Oficina de Informação, acompanhando toda situação do lado de fora, convidou a educadora do Pré, para que ela viesse para fora, mas ela não aceitou, alegando que tinha preparado uma história e outras atividades. As crianças do Alô-Alô não perceberam nada e continuaram explorando os vários espaços do pátio e, principalmente, o tanque de areia. 
Logo depois, porém, a educadora do Pré saiu com grupo, dizendo: "Não deu para segurar". As meninas corriam de um lado para o outro, diziam em coro: "Muito prazer!" As crianças do Alô-Alô continuavam brincando sem dar nenhuma atenção.

Então, as educadoras tiveram a idéia de fazer uma grande roda no pátio, convidando tanto as crianças do Alô-Alô quanto as da Creche/ Pré Escola Oeste para uma apresentação. Organizei um dinâmica em que as crianças deram várias gargalhadas: no momento em que iam se apresentar, falavam o seu próprio nome e o restante do grupo, em coro, repetia, como se fosse um eco.

O Pré também foi mostrar ao Alô-Alô a composteira da Creche, espaço que acondiciona o resíduo orgânico que se transforma em adubo. As crianças olharam rapidamente e continuaram brincando. A professora do Alô-Alô chamou o grupo para conhecer a Oficina de Informação, senão daria tempo, pois logo precisariam voltar. Neste momento, as crianças do Pré se despediram e voltaram para a sala. Ao adentrarem na Oficina de Informação, as crianças avistaram os fantoches de vários personagens, que estão expostos em uma das prateleiras. Quase todas queriam mexer, causando uma certa disputa entre elas.

Uma menina, ao ver o computador, pediu à educadora da Oficina de Informação: "Liga essa tv, tia". E a educadora respondeu com uma expressão de espanto: "Isso é um computador!" A menina insistiu "Mas o que tem dentro?" Logo chamaram a educadora e o diálogo acabou naquele momento.

As almofadas com formato de bichos (cobra, sapo e tartaruga) que compõem o espaço, criando um clima aconchegante e lúdico, transformaram-se em bolas, pois as crianças pulavam de um lado para o outro, deixando uma atmosfera agitada. 
As caixas que acondicionam os livros, sustentadas por estruturas de madeira com rodinhas, foram utilizadas pelas crianças como carrinhos de rolemã. A educadora da Oficina teve que, rapidamente, retirar as estruturas, pois estavam se tornando perigosas para o espaço. Observei que, neste momento de exploração e reconhecimento do espaço pelas crianças, os livros foram os objetos menos manuseados, pois queriam brincar, pular, correr, jogar almofadas e assistir televisão.

A educadora da Oficina de Informação chamou o grupo para explicar como seria o procedimento de empréstimo de livros. Somente neste momento as crianças puderam se voltar para os livros e a grande maioria escolheu o primeiro livro que pegou na caixa. Percebemos, porém, que uma das meninas do grupo, além de olhar várias vezes os livros para escolher um, continuou folheando outros, demonstrando uma grande intimidade com o objeto. Quando o grupo já estava se organizando para ir embora, essa mesma menina contou: "Aqui nessa creche fica o meu primo, eu já li vários livros que ele trouxe da creche para minha casa. 0 depoimento dessa garota foi revelador, comprovando que a política de empréstimo domiciliar contempla não só as crianças inseridas na Instituição, mas familiares e pessoas do entorno.

As crianças do Alô-Alô escolheram livros para levar para sua escola. ${ }^{23}$

23

\begin{tabular}{|l|l|}
\hline \multicolumn{1}{|c|}{ Título } & \multicolumn{1}{c|}{ Autor } \\
\hline Deu Zebra & Carlos Q. Telles \\
\hline Contos e lendas de amor & Latino Americano \\
\hline Gato de briga de paz & Miriam Mermelstein \\
\hline Dinossauros salvem a terra & Laurre K.Broun \\
\hline Brincando com os números & Massin \\
\hline O segredo de U & Ziraldo \\
\hline Fábula de Esopo & Ruth Rocha \\
\hline Bruxa Onilda Vai a Paris & L Larreula \\
\hline A letra N & Ziraldo \\
\hline Poemas sapecas, rimas traquinas & Almir Correia \\
\hline O Reino do Aqui - pode & Alexandre Azevedo \\
\hline & \\
\hline
\end{tabular}


A segunda visita aconteceu no dia 28 de setembro. A Pré Escola Alô-Alô agora foi recepcionada pelas próprias crianças do Pré da Creche/Pré Escola Oeste, que organizaram mesas e cadeiras para, juntos, lancharem ao ar livre.

Uma das crianças do Pré havia escrito uma carta às crianças do grupo Alô-Alô, expressando o prazer de tê-la na Creche; esta foi lida pela professora, antes de as crianças começarem a comer.

Como as crianças já haviam conhecido o espaço externo da Creche e o tempo era um pouco curto, a professora pediu que, depois do lanche, o grupo fosse direto à Oficina de Informação. Desta vez, o movimento das crianças estava um pouco diferente do $1^{\circ}$ dia, pois, quando viram os livros acondicionados na caixa, 5 crianças foram logo manuseá-los. Uma das meninas encontrou um livro com a imagem do Saci Pererê e chamou duas amigas para compartilhar a descoberta. Um grupo se dirigiu até os fantoches e os passavam de mão em mão. Depois, o restante do grupo chegou e algumas crianças foram até as caixas dos livros, onde, desta vez, encontraram a coleção "Segredo das letras" do Ziraldo e da "Bruxa Onilda". Além dos amigos, estas crianças chamaram também sua professora, dizendo "Olha o livro que a gente leu na escola".

\begin{tabular}{|l|l|}
\hline Noel Tropical & Aline Zoz \\
\hline O casamento da Emília & Monteiro Castanha \\
\hline Anedotinhas do bichinho da maçã & Ziraldo \\
\hline O príncipe sapo & Contos \\
\hline Os minpins & Ronald Dahl \\
\hline Não quero ir para a cama & Julie Suykes \\
\hline Os cisnes selvagens & Contos \\
\hline Jowons ensemble & Pere Castor \\
\hline Aorupaço, Paco e tal! & Sylvia Orthof \\
\hline O casamento da bruxa Onilda & E.Larreula \\
\hline A Bela Adormecida & Mônica Stahel \\
\hline O menino de olho d'água & José Paulo Paes \\
\hline
\end{tabular}


A professora me contou que o grupo do período da manhã, de sua escola, estava realizando um trabalho sobre o folclore e a imagem do Saci estava na parede da sala. Por isso, as crianças reconheceram-no na ilustração do livro.

A educadora da Oficina de Informação havia preparado uma história para contar ao grupo. A maioria das crianças foi para a roda com livros e fantoches nas mãos. Uma das pessoas que acompanhava o grupo no percurso, responsável pela Escola Alô-Alô e pelas aulas de religião, tirou os fantoches das mãos de algumas crianças que estavam mais próximas, dizendo que a hora era de ouvir histórias e prestar atenção.

Depois, a educadora da Oficina de Informação colocou a fita do Rei Leão, atendendo aos inúmeros pedidos. Todas as crianças se sentaram em frente à TV, recostadas nas almofadas que cada uma encontrou, na posição que mais the agradasse. Ao começar o filme, o grupo comentava que já o conhecia ou era a primeira vez que estava assistindo. Quem já tinha um conhecimento das cenas e personagens, ia antecipando aos amigos que, por sua vez, colocavam em dúvida as informações. Mas quando aparecia a cena na tela, era uma euforia: "Tá vendo, eu não te disse!" Um menino, depois da apresentação do filme, disse "está terminado". Logo o seu colega respondeu "Não, está começando". As crianças trocaram de posição diversas vezes, mas em um dado momento, todas estavam deitadas, parecendo uma coberta de crianças estendida no chão.

Simultaneamente ao filme, as crianças também escolhiam os livros para levarem para a sua escola. Algumas crianças continuaram brincando muito com as almofadas, principalmente as de formato de bichos, chegando quase a estragálas.

A educadora da Oficina de Informação convidou as crianças para ouvir a história "Marcelo, Marmelo, Martelo". Esse personagem troca o nome das pessoas e objetos. Ela perguntou às crianças por que, ao invés de falar leite, o personagem 
nomeou-o suco da vaca. As crianças responderam: "Porque foi Deus quem criou a vaca".

O filme não pôde ser assistido até o final, pois um dos adultos que acompanhava o grupo precisava ir embora. As crianças ficaram muito bravas com essa atitude, cruzaram os braços, encheram a boca de ar e manifestaram verbalmente a sua indignação. No final da visita, as crianças escolheram livros para levar à escola ${ }^{24}$

O terceiro encontro aconteceu no 7 de novembro. As crianças do Pré continuaram organizando o espaço para o café da tarde e lanchando com as crianças do AlôAlô.

Depois o grupo visitante subiu à Oficina de Informação, mas, desta vez, a TV não estava no espaço. As crianças, num primeiro momento, nem perceberam a ausência do aparelho, pois foram direto aos livros e fantoches. Não demorou muito, alguém chamou a atenção do grupo: "Cadê a televisão?" A educadora explicou que estava organizando o espaço de um outro jeito. Mas avisou para as crianças que contaria uma história.

24

\begin{tabular}{|l|l|}
\hline \multicolumn{1}{|c|}{ Livro } & \multicolumn{1}{c|}{ Autor } \\
\hline O Anjinho Danado & Maria Julieta Sebastiani \\
\hline Zé Pedro comeu & Ricardo Azevedo \\
\hline Contos de fadas húngaros & Maria Lúcia Pessoa de Barros \\
\hline A família Yorkshire & Enrice Braido \\
\hline Marzão & Teresa Noronha \\
\hline História da Carochinha & Lenice Bueno da Silva \\
\hline O Soluço da Raposa & Nich Buttirucorth \\
\hline Bruxa Onilda vai a Inglaterra & E. Larreula \\
\hline Meu livro de folclore & Ricardo Azevedo \\
\hline Artistas Famosos Monet & Antony Mason \\
\hline O elefante e o camelo & Ruth Hurlimann \\
\hline Contos de Piratas, Corsários e Bandidos & \\
\hline Marcelo, Marmelo, Martelo & Ruth Rocha \\
\hline Você troca? & Eva Furnari \\
\hline O castor cozinheiro & Lars Klinting \\
\hline
\end{tabular}


Algumas crianças quiseram ouvir a história, outras preferiram brincar com os fantoches e o restante ficou mexendo nas caixas com os livros. O movimento das crianças estava um pouco diferente com relação aos fantoches; se muitas vezes eles tinham sido motivos de disputa por sua posse, agora as crianças brincavam harmonicamente com os materiais, inclusive, dramatizando histórias. Perguntei à professora se ela tinha percebido a diferença. Ela informou que a Grim (responsável pelo grupo), ao constatar o interesse das crianças pelos fantoches na Oficina de Informação, comprara diversos deles para a escola.

Três meninas encontraram, uma de cada vez, no acervo, livros sobre artes visuais. Uma delas trouxe para a sua professora o livro "Almeida Junior" dizendo: "Olha o que eu encontrei, é o livro do Monet!" Outro livro de arte apareceu e, mais tarde, o do próprio Monet. A menina se sentou bem perto da professora e foi contando a biografia do artista, a partir das imagens. A professora contou que as crianças estavam pesquisando, na escola, sobre as obras do artista Monet; por isso, mostravam a ela o que encontravam.

Do outro lado do espaço, estava a educadora da Oficina de Informação, contando a história para o grupo que se interessou em ouvi-la. Ao terminar a história, mostrou às crianças a caixa que contempla os contos de fadas.

$\mathrm{Na}$ hora de emprestar os livros para a escola, percebi que uma boa parte das crianças foi escolher os livros sobre contos, outra, sobre artes visuais.

No dia 14 de novembro, resolvi realizar um visita na Pré escola Alô-Alô com o intuito de saber como as crianças estavam utilizando os livros. Ao chegar na escola, percebi um movimento diferente, pois além da professora e da Grim, havia cinco jovens estudantes da Escola Estadual "Alberto Torres" que participavam do projeto Biblioteca Viva; haviam escolhido a Escola Alô-Alô para contar histórias, uma vez por semana. O grupo estava distribuído na sala e no quintal e cada estudante lia um livro para, aproximadamente, quatro crianças. Clima descontraído, posição corporal para leitura de acordo com o desejo das crianças. 
Percebi que o contato físico com as jovens tinha um significado muito grande para aquelas crianças; beijavam suas faces, acariciavam os seus cabelos, deitavam suas cabeças sobre seus colos.

Entrevistei a professora Márcia sobre como as crianças estavam utilizando os livros emprestados pela Oficina de Informação e os livros da própria escola. Apesar de a escola ter um suporte de madeira para colocar os livros, estes ficavam dentro do armário, sob a justificativa de que precisavam ser guardados para não sumirem ou serem danificados, já que a sala também era utilizada por adultos no período noturno e havia a possibilidade de furtos durante as madrugadas.

A professora contou-me que é ela quem decide os momentos de manuseio dos livros, no começo do período ou no final; coloca-os em cima da mesa para quem quiser, e às vezes lê alguma história na roda. Em outras situações, como nas visitas dos jovens contadores, os materiais ficam guardados para não misturar com os livros da própria escola ou do projeto Biblioteca Viva. Quando estava saindo da escola, as crianças me presentearam com um cartão ilustrado por elas mesmas, agradecendo a parceria. 

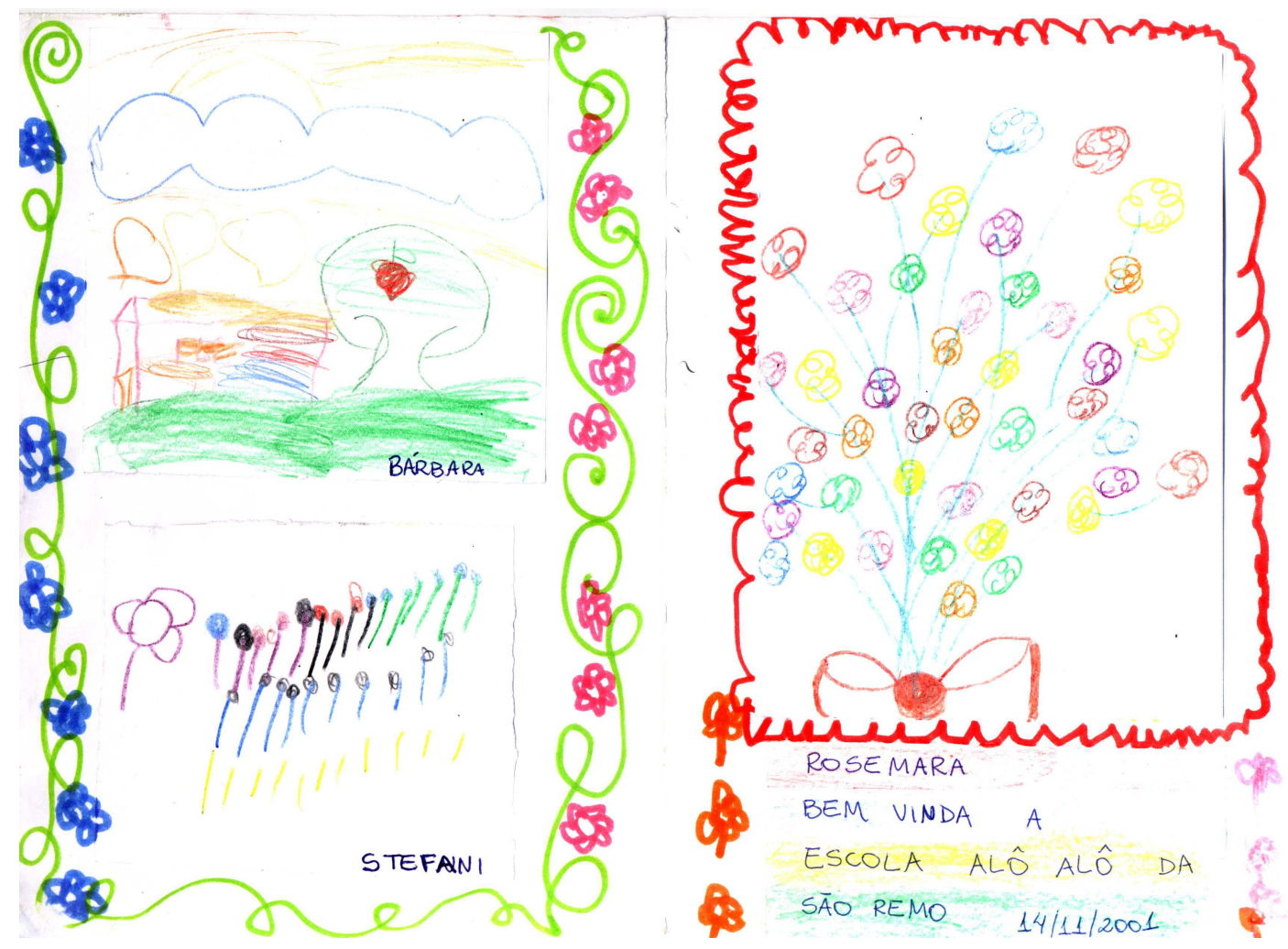

Figura 4 - Cartão (Frente)

No dia 22 de novembro deu-se a tão esperada visita das crianças do Pré da Creche/Pré Escola Oeste na Escola Alô-Alô. Estavam ansiosas para conhecerem o espaço, sabiam que caminhariam bastante, mas não se importaram. Afinal, foram elas mesmas que tiveram a idéia. A caminhada não foi nada fácil até o Hospital Universitário, principalmente porque o sol estava ardente.

E, pela primeira vez, a maioria das crianças da Creche/Pré Escola Oeste adentrou em uma favela, exceto as três crianças que moravam no local. Os dois meninos, orgulhosos, mostraram o caminho para chegar à comunidade São Remo. Tudo era uma grande novidade para aquelas crianças, a rua com várias barracas de doce e aguardente e as carroças de cavalos circulando. O estranhamento se deu quando as crianças entraram na escola adaptada, casa de alvenaria com um quintal pequenino. Percebemos neste encontro que as crianças na idade de 
Educação Infantil estão mais abertas para enfrentar o novo e o diferente, o preconceito ainda não está tão arraigado como nos adultos.

Quando o grupo chegou à escola, as crianças do Alô-Alô estavam na porta gritando e acenando. O pequeno espaço se transformou num lugar aconchegante com um tapete azul no chão. O suporte de madeira estava repleto de livros, as mesas organizadas com propostas diversas e simultâneas. As crianças da Creche foram entrando e se sentando no tapete; estranharam o espaço, e perguntaram: "Por que essa escola é tão pequena?".
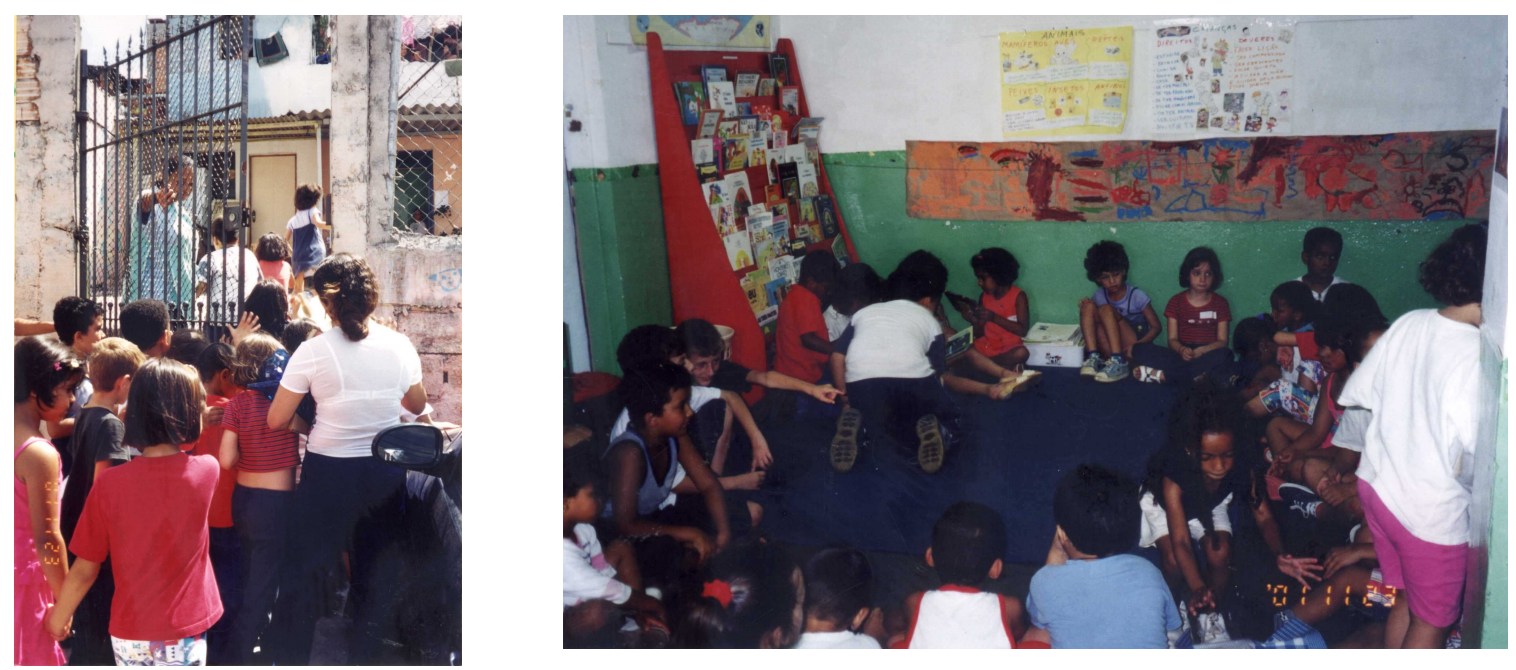

A professora Márcia, com muita propriedade e sensibilidade, estabeleceu comparações entre os espaços institucionais, pontuando diferenças sem marcar a desigualdade. Logo depois, as crianças escolheram as propostas. As meninas preferiram brincar de bambolê no quintal, admirando uma criança da Escola AlôAlô que, com muita competência, girava na cintura aquele arco.

De repente, uma menina do Alô-Alô fez um pedido, dizendo que gostaria de ouvir uma história lida por uma criança. Três meninas do Pré começaram a contar a história dos autores Mary França e Eliardo França. A professora Márcia informou que, na escola, o grupo não tinha visto nenhuma leitura feita por criança lendo. 


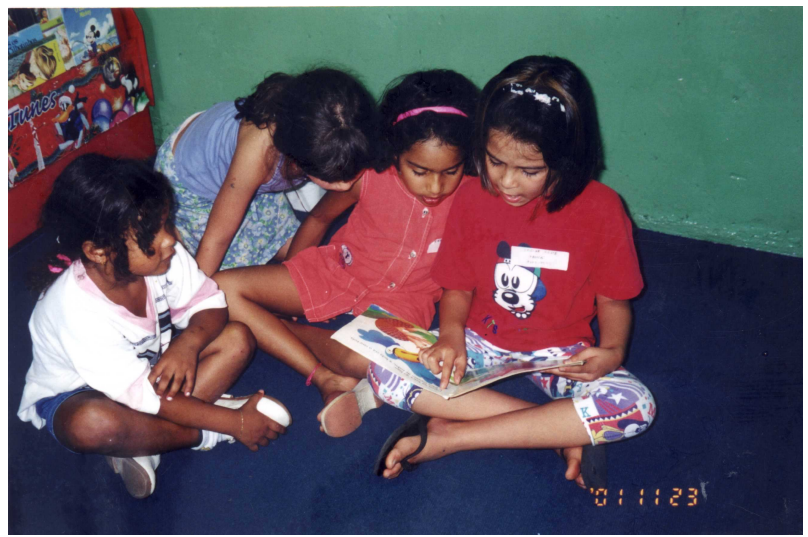

A escola havia preparado dois sucos e um deles era "maluco", inspirado na proposta desenvolvida na Creche Central, pois a professora Márcia (que trabalha em uma das Creches da USP), havia aprendido essa receita culinária. Os sucos eram de cenoura com laranja e laranja com água; as crianças adoraram e elogiaram bastante, até pediram a receita.

Houve também a troca de presentes de ambas a partes. As crianças do Alô-Alô deram vários desenhos e o grupo do Pré trouxe algumas fotos dos momentos vividos por eles na Creche. Todos ficaram super contentes.

A professora combinou comigo que o Alô-Alô iria à Creche somente mais uma vez para entregar os livros, pois estavam se preparando para a formatura e encerramento das aulas.

No dia 30 de novembro foi a última visita do ano do grupo Alô-Alô à Oficina de Informação. Depois do lanche, as crianças do Pré fizeram uma apresentação para o grupo Alô-Alô, no pátio. Ao entrarem na Oficina, as crianças do Alô-Alô tiveram uma grande surpresa, pois lá estava uma exposição das fotos de situações vivenciadas na parceria entre Creche e comunidade São Remo. Uma das crianças, enquanto contemplava as fotos, chamou os colegas e a professora. Todas as crianças olhavam cada detalhe das imagens, até lembraram dos amigos que não faziam mais parte do grupo. Ficaram um bom tempo admirando as fotos. 
Os pedidos para colocar um vídeo foram inúmeros. Foi então que a educadora da Oficina de Informação disse: "Hoje vocês vão assistir a uma história diferente". Todas as crianças se sentaram em frente à TV e, quando apareceram as primeiras imagens, foi uma grande emoção: gritaram, apontaram, sorriam, etc. Desta vez, as almofadas, os fantoches não tiveram ênfase no espaço, porque estavam fascinadas com os personagens do filme: elas mesmas.
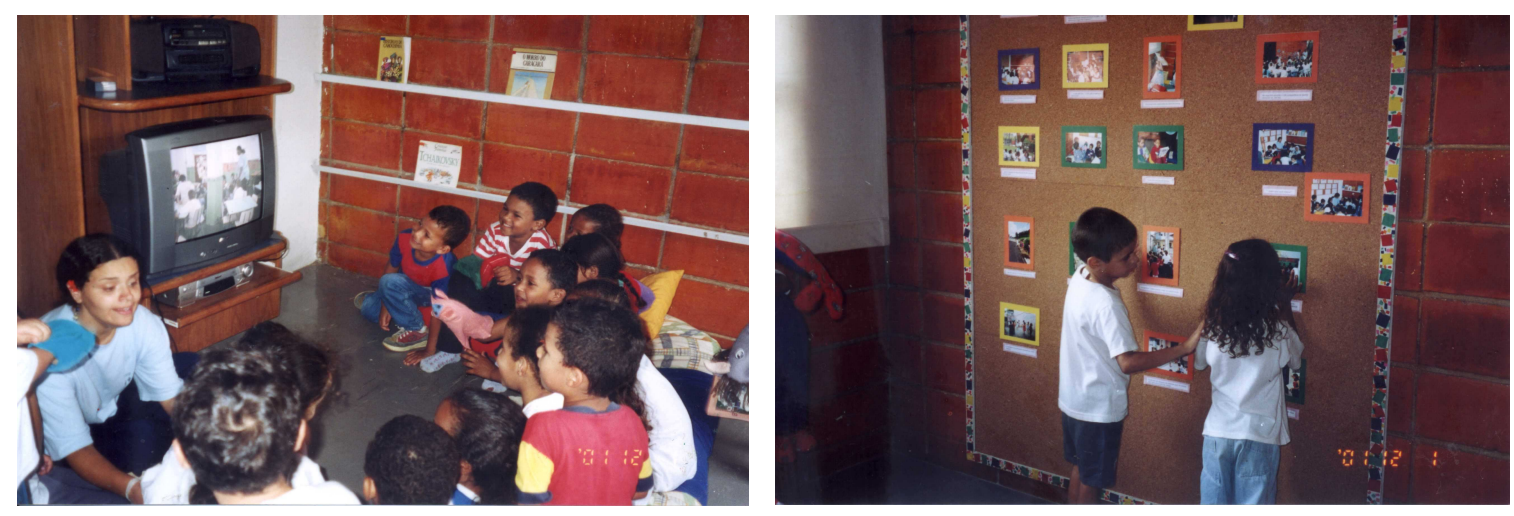

Frutos da parceira. Abrir a Oficina de Informação para a comunidade do entorno possibilitou um elo entre crianças de classes sociais diferentes. Não havia imaginado que esse contrato com a Escola Alô-Alô pudesse contribuir diretamente para a proposta pedagógica da Creche/Pré Escola Oeste. Foram as próprias crianças que apontaram essa necessidade e a vontade de conhecer o novo grupo e o espaço da Escola Alô-Alô, localizada na comunidade São Remo.

A expressão da desigualdade foi traduzida pela diferença do atendimento às crianças, em vários aspectos: espaços, recursos materiais e humanos. Não muito longe, do outro lado do muro da Universidade de São Paulo, encontramos um local adaptado para receber crianças com diversas pessoas voluntárias para mantê-lo. Já do lado de cá do mesmo muro, existem crianças atendidas em uma Creche de referência para todo Brasil. Mas na pequena passagem do muro, as crianças, independentemente de classe social, religião, etnia, família, puderam compartilhar sonhos, desejos, brincadeiras, espaços, sabores e saberes. 
Momentos mágicos como esses terão que ser, necessariamente, fortuitos no país?

Enfim, tivemos a possibilidade de viver experiências ímpares, provocadas pela Oficina de Informação, porém sem perder de vista a importância de lutar junto às políticas vigentes, pelo direito à educação de qualidade, legitimada pela Constituição Brasileira para todos os cidadãos.

Os encontros foram acontecendo no ano de 2002. Já no início do $1^{\circ}$ semestre do ano de 2003, devido a algumas mudanças de ordem administrativa da Escola AlôAlô, agora chamada Escola Girassol, o grupo não pode mais freqüentar a Oficina de Informação. Mas, em meados de abril, a Creche/Pré Escola Oeste recebeu um telefonema dizendo que as próprias crianças do Girassol estavam cobrando o retorno à Oficina de Informação. Tivemos mais dois encontros, porém a seqüência foi interrompida devido à reforma da Creche/Pré Escola Oeste.

Em 2004, no início do ano, a Escola Girassol entrou em contato com a Creche/Pré Escola Oeste, convidando a coordenação e a educadora da Oficina de Informação para conhecerem o prédio novo da Escola, mas a greve e a reforma nos telhados impediram o encontro.

\subsection{8 - Dez anos de Oficina de Informação}

Em novembro de 2004, a Oficina de Informação completou dez anos. A data não marcava apenas um tempo cronológico, mas demarcava um tempo de construção e parcerias; por isso, merecia ser comemorada com uma festa em grande estilo.

A princípio, as idéias para a grande festa de aniversário estavam sendo elaboradas pela educadora da Oficina de Informação, Ana Helena. Mas, infelizmente, a proposta da comemoração foi interrompida, por dois motivos: o 
primeiro, ocorrido no $1^{\circ}$ semestre, foi uma greve de mais de 62 dias; já o segundo aconteceu no $2^{\circ}$ semestre, devido à reforma emergencial dos telhados, que cito anteriormente.

Voltou à baila, no mês de janeiro de 2005, a discussão sobre a comemoração dos dez anos de Oficina de Informação. Com a participação de todos os funcionários, a Ana Helena pôde expor suas idéias para a comemoração. A elas, outras sugestões foram se somando: convites para editoras exporem livros, participação de contadoras de histórias, palestras para adultos, coquetel para encerrar o evento, etc. A festa, em grande estilo, será realizada quando a Oficina de Informação completar 11 anos; o grupo achou que tinha mais sentido, pois estava muito longe do mês oficial de seu aniversário. Até o mês de novembro, a comissão de festa tem muito por fazer. 
PARTE III 


\section{3 - Diálogo com os depoimentos}

Um dia num campo de ovelhas

Vi um homem de verdes orelhas

Ele era bem velho, bastante idade tinha

Só sua orelha ficara verdinha

Sentei-me então a seu lado

A fim de ver melhor, com cuidado

Senhor, desculpe-me minha ousadia, mas na sua idade

de uma orelha tão verde, qual a utilidade?

Ele me disse, já sou velho, mas veja que coisa linda

De um menino tenho a orelha ainda

É uma orelha-criança que me ajuda a compreender

O que os grandes não querem mais entender

Ouço a voz de pedras e passarinhos

Nuvens passando, cascatas e riachinhos

Das conversas de crianças, obscuras ao adulto Compreendo sem dificuldade o sentido oculto

Foi o que o homem de verdes orelhas

Me disse no campo de ovelhas.

Gianni Rodari

Nesta parte, apresentamos depoimentos de sujeitos que contribuíram decisivamente na construção da Oficina de Informação. O critério para a escolha não pretendeu abarcar o depoimento de todos os participantes, uma vez que nossa opção metodológica foi pela pesquisa qualitativa e não quantitativa. Buscamos um conjunto de depoimentos representativos para evidenciar o papel do dispositivo de informação no processo educativo. Entramos em contato com vários profissionais, famílias e alguns adolescentes ${ }^{25}$ envolvidos na construção da

\footnotetext{
${ }^{25}$ Esclarecemos que não consideramos, para coleta de depoimentos, as crianças "bem pequenas", que atualmente freqüentam a creche, mas buscamos o registro de crianças que a freqüentaram no período de implantação e desenvolvimento da Oficina de Informação; atualmente, elas são adolescentes e, por diversos motivos, ainda mantém contato conosco.
} 
Oficina de Informação. Solicitamos a todos um depoimento, mas respeitamos o movimento de cada um, não insistindo por demasiado no retorno dos registros. Apresentamos aqui todos os depoimentos a nós encaminhados, assim distribuídos: ${ }^{26}$ :usuários 6 , funcionários 12 , pesquisadores 6 , somando um total de 24 depoimentos.

\section{1 - Depoimentos de Usuários}

\section{- Pais}

Cristina, mãe do Bruno que freqüentou a Creche Oeste até o ano de 2003.

"Com relação à Oficina de Informação e à tua pergunta a respeito do que nos motivava a colaborar com o projeto, a resposta é mesmo a nossa vontade de retribuir, pelo menos um pouquinho, o que a Creche nos proporcionava. É claro que a opção por contribuir com o acervo da Oficina de Informação foi baseado na constatação de quão importância é este projeto: a ânsia das crianças em subir para aquele espaço para escolher livros e fitas de vídeo era evidente. Além disso, em conversas com os outros pais percebíamos como eles valorizavam esta oportunidade, que de outra forma seria difícil para muitas famílias proporcionar aos filhos. Tenho certeza de que muitas crianças descobriram naquela sala que pode ser muito prazeroso conhecer o mundo através dos livros. Estes aprendizados são uma das melhores heranças que eu

\footnotetext{
${ }^{26}$ Como atual diretora da Creche e coordenadora pedagógica, agradeço às pessoas a quem tive acesso e disponibilizaram-se para escrever o depoimento. Âqueles, que por diferentes motivos não se encontram aqui representados em suas escritas, registramos o respeito e agradecimento.
} 
recebi dos meus pais, e por isso eu prezo tanto o empenho de vocês em passar esta mensagem para as crianças. Mais uma vez obrigado por tudo Um abraço"

\section{Cristina}

S.P, agosto de 2004

$$
* * *
$$

Sílvia, mãe da Maria Clara que freqüenta a Creche Oeste no G4.

"Um dia, entrei na creche de manhã para deixar minha filha, Maria Clara, e encontrei minha inspiração; o que fazer com as tantas fotos tiradas do dia a dia na creche.

Sim, pois adoro fotos, e então de tempos em tempos, deixo a máquina fotográfica com as educadoras, para que elas possam deixar gravadas para sempre momentos tão bonitos e deliciosos da infância de minha filha.

Mas, voltando para minha fonte de inspiração, quando vi aquelas pastas com fotos, não me lembro exatamente do que, acho que eram de alguns passeios das crianças, fiquei encantada. Aí pensei: "é desta forma que vou organizar as fotos tiradas aqui na creche"; só que havia um problema: eu já havia arrumado a maioria no álbum de fotos dela; teria que desmontá-lo todinho; então me enchi de coragem e o fiz. Desmontei, separei todas as fotos da creche, montei novamente em sua ordem cronológica. 
Então veio a outra parte: comecei a organizar por cada ano que se passou; ainda bem que tenho o hábito de marcar datas no verso das fotos, pois me ajudou muito.

$E$ teve um outro detalhe, pois quando vi as pastas, fiquei interessada por algumas fotos tiradas pela creche, então fui a procura com a ajuda da educadora que cuidava da Oficina, na época era a Nice, mas não fui muito feliz, pois só pelos negativos era impossivel descobrir as fotos da Maria Clara, e os negativos não tinham nenhuma forma de identificação para ajudar. Fiquei pasma ao saber, que ninguém procurava por aqueles negativos; como que nenhum pai/mãe, subia naquela salinha preciosa, para resgatar estes tesouros de seus filhos!!! Sim, pois aquela salinha, a Oficina, é um encanto: parece um mundo à parte; adoro quando tem reuniões ali... Inclusive, em uma das reuniões, tinha um monte de fotos expostas dos nossos príncipes e princesas... uma mais linda que a outra!!!

Já estou com quatro pastas montadas, e atualmente estou fazendo a pasta deste ano, o G4. Dá um certo trabalho, pois não me acho muito criativa, mas têm sido um trabalho muito gostoso. Guardo todas as figuras e desenhos que possa aproveitar na montagem. Acho que quando ela tiver crescido, vai ser uma recordação muito boa. Recordação do tempo que ela vivia num mundo $e$ fantasias, princesas; um período aonde ela achou suas primeiras amigas, e recebeu muito carinho de todos. 
Através destas pastas, eu e meu marido, queremos passar para ela, o quanto a creche foi importante nos seus primeiros anos de vida; o quanto aquele "cantinho especial" trouxe de histórias e mais histórias para sua vida!!

Tanto que, no seu último aniversário, ela ganhou vários DVs, os quais já tinha em VHS, e a primeira idéia do meu marido foi de doar as fitas para o Oficina da creche, pois sabemos o quanto isso irá contribuir para aqueles momentos tão gostosos dela e de outros que ali estarão."

Sílvia

S. P, novembro de 2004

$* * *$

Elaine, mãe da Lucilla que freqüentou a Creche Oeste até o ano de 2002.

"Rose, me desculpe a demora em escrever, mas estamos num período de muitos afazeres. Conversei com a Lucilla sobre a Oficina de Leitura e ela tem lembranças da televisão, da almofada de cobra, tartaruga e jacaré. Lembrou das caixas com muitos livros e da sacolinha onde eles levavam os livros para casa. As rodas de estória e depois, as conversas com os amigos. Uma lembrança que marcou muito foi o filme do "Gorila" que salvou a criança na roda-gigante do parque, e que ela chorou muito. Ela me disse que foi na oficina que ela aprendeu a gostar de ler e do quanto aquele lugar era especial. As minhas lembranças são maravilhosas e pude compartilhar do espaço e do aconchego da Oficina em diversas ocasiões. Aliás, era um lugar especial, onde a gente gostaria de se recolher, deitar nas almofadas e entrar naquele mundo cheio de 
fantasias. Eu, assim como a Lucilla, também tinha muito carinho pela sacolinha que trazia os livrinhos para casa. Foi um período de grande aprendizado, pois eu não tive, na minha infância, acesso a livros e muito menos a estórias infantis.

Foi através da Oficina que eu conheci esse mundo tão mágico e lendo para a Lucilla eu aprendi a contar estórias. Nada pode sertão gratificante do que isso. E a alegria, as risadas. Um livro que me fez dar muitas risadas foi "Mamãe botou um ovo". Ele retrata bem as dificuldades dos pais em falar aos filhos sobre como os bebês são concebidos e, para variar, os filhos é que dão uma aula de conhecimento sobre o assunto. $O$ meu desejo mais profundo é que todas as crianças pudessem ter a oportunidade desse contato com a Oficina de leitura. Eu e a Lucilla somos muito gratas a esse projeto, que eu espero, continue crescendo e proporcionando "felicidade" e "risos". Beijos"

Elaine

SP, novembro de 2004

$* * *$

Márcia, mãe do Jorge e Luis que freqüentam a Creche/Pré Escola Oeste.

\section{A LEITURA NA VIDA DOS MEUS FILHOS}

"Iniciarei por contar que tenho dois filhos, Jorge Marcelo com 6 anos e Luis Enrique com 3. Ambos estudam na Creche Pré escola Oeste da Universidade de São Paulo. 
Pensando na relação deles com a leitura me pergunto, em que momento a criança começa esta relação? Talvez possamos dizer que tudo começa muito antes do imaginado, com a criança folhando aqueles livros de pano ou de folhas duras e grossas, sempre muito coloridos.

Durante estes anos na creche meus filhos aprenderam muitas coisas, a se relacionar com o mundo, a respeitar a natureza, as outras pessoas e a si mesmos, e a gostar de livros. Será o início de um futuro gosto pela leitura?. Já no berçário lembro da educadora dizendo: ele gosta muito de ler. Eu olhava para meu marido e pensava na frase, ler? Sim e é que existem vários tipos de leitura. Percebemos que as crianças lêem os livros através das figuras e que na casinha do berçário, livros podiam ser encontrados com facilidade. Quando Jorge estava no berçário gostava de algumas histórias, mas o que mais chamou nossa atenção neste período foi o fato de lembrar o nome dos autores. Ainda hoje posso lembrar dele pequeno dizendo: Mãe olha! Este livro é da Mary França e do Eliardo França. Até hoje ele pergunta o autor de alguns livros do seu interesse como Harry Potter. Hoje quando alguma mãe me pergunta sobre algum livro para crianças pequenas, eu lembro do meu filho pequenininho dizendo que gostava dos livros da Mary França para espanto das tias e avós.Quando meu filho mais novo começou a freqüentar a creche, eu me perguntava se ele teria o mesmo gosto pelos livros que o irmão? Por ser mais agitado em casa, imaginava que talvez os interesses dele fossem ser outros menos literários e mais esportivos. Grande engano, a ida para a "Oficina de Informação" é para ele uma aventura, Jorge você viu o livro do bumbum? Perguntava para o irmão. Os livros que ele traz da oficina não podem ser devolvidos até terminar a leitura de todas as historinhas e como algumas vezes 
são livros extensos leva mais tempo do que permitido pela creche. Um dia eu peguei um livro que falava sobre os índios, emprestado já fazia uma semana, e levei para a creche com a finalidade de devolução do material no lugar indicado, de repente olho para o rosto zangado dele dizendo: mãe eu estou muito bravo com você! Nós ainda não terminamos de ler este livro, tentei convencê-lo de que o livro tinha muitas histórias longas e já tínhamos lido várias, mas ele insistiu e o resultado foi voltarmos para casa com o livro que tanto interesse despertava nele: os índios. Naquele dia concluí que incentivar a leitura nos filhos não depende só da escola, mas da paciência e interesse dos pais.

Ao contrário do irmão, ele não traz livros toda semana, mas somente quando realmente tem algum interesse. Lembro que na semana seguinte ele trouxe um livro da creche e disse para mim: mãe eu trouxe um livro "curtinho" para você poder ler. Ainda falando sobre a relação de meu filho mais novo com os livros, neste último ano ele começou a pedir para "ficar um pouquinho" na hora em que chegamos à creche. Ele gosta de ficar na sala (talvez imitando o irmão mais velho). Bom, em realidade o que ele quer é contar para mim o que eles estão lendo na sala. Mãe senta aí, olha "o morango silvestre maduro", eu vou contar pra você, mãe "os pingos", mãe "chapeuzinho vermelho", "Rapunzel" e já aconteceu de eu estar com alguma pressa e dizer para ele contar só um pedacinho, mas ele insiste em terminar a história e quando não lembra uma parte, pede para ler essa página que ele esqueceu. Luis gosta de acompanhar o irmão para a sala do G5, talvez seja o fato de ir para o módulo II, onde tem crianças grandes, e ai, fica observando o material e alguns livros, os mapas chamam particularmente sua atenção e heróis como Hércules ou o cavalo Pégasus. 
Terminando este depoimento com meu filho mais velho, um tempo atrás ao ver o livro do Harry Potter em casa, disse: Mãe esse é o livro do arry Hotter! Você pode ler para nós? Sim posso, respondi, mas Jorge não tem figuras é só escrita. Não tem importância ele disse. Comecei a leitura lembrando das críticas nos jornais e televisão à famosa série de J.K. Rowling. Tudo bem, pensei, eles já assistiram os filmes inúmeras vezes. Após o primeiro capítulo, uma noite meu filho mais velho disse, mãe essa parte não tem no filme, então o livro tem partes que os filmes não mostram? Sim, eu disse, os filmes são baseados nos livros, só que 2 horas de filme não dá para mostrar tudo, por isso os autores têm que resumir. Posso levar para a creche? Pode respondi, mas só tem letras, não tem figuras. Ele queria mostrar para a educadora e os colegas e comentar que tinha cenas que eles não tinham visto nos filmes. $O$ livro voltou bastante folhado, os dedinhos marcados em várias páginas. Olhei para o livro feliz, eles ainda não sabem ler, pensei, como é que ficaram folhando um livro no qual somente tem letras? Meu filho já levou para a creche alguns livros e os colegas demonstraram sempre muito interesse, na turma dele nunca um livro voltou rasgado. Assim também ele voltou um dia, dizendo que o colega tinha levado uma fita e um livro em japonês! E ele tinha visto como é a escrita no japão! Algo de muita emoção, descobrir que existem outros tipos de letras em outros lugares do mundo.

São inúmeras as anedotas que podem ser contadas neste sentido, a cada ano que passa o papel da creche no desenvolvimento do "gostar de ler", ainda mais diria eu, da compreensão da leitura, no sentido de compreender que o que está 
escrito é uma história e pode ser muito interessante, fica evidente na vida dos meus filhos e das outras crianças da creche.

É muito bom para um pai ver dentro dessa "bagunça organizada" nos horários de entrada e saída, enquanto umas crianças correm, outras brincam, desenham, conversam, alguma vez pode-se observar uma folhando um livro interessada em um cantinho ou um grupinho sentado em roda observando um livro ou revista. 0 acesso aos livros em todo momento, tanto na sala como na Oficina de Informação, a rotina de levar livros para casa e devolvê-los no tempo correto, o poder compartilhar com os colegas, o aprender que leitura é um prazer e não uma obrigação, fazem com que estas crianças descubram aos poucos o mundo maravilhoso dos livros na era do computador, internet e vídeo games. Imagino que no futuro estes pequenos leitores passarão a ser grandes leitores e alguns provavelmente influenciem seus pais a se tornar leitores também. Só nos resta esperar que este trabalho tenha continuidade na vida de cada um deles no Ensino Fundamental."

Márcia

S.P, dezembro de 2004

As práticas propostas pela Oficina de Informação, de acordo com os pais, interferem na formação dos seus filhos. A possibilidade de os livros e vídeos circularem nas casas das crianças proporcionam vínculos entre a comunidade, a Creche e a leitura, desafiando a família, muitas vezes, a contribuir nesse processo. 
Em um dos depoimentos, uma mãe declara:

"Foi um período de grande aprendizado, pois eu não tive, na minha infância, acesso a livros e muito menos a estórias infantis. Foi através da Oficina que eu conheci esse mundo tão mágico e lendo para a Lucilla eu aprendi a contar estórias."

E nesse diálogo entre mãe e filha, mediado pelo livro, muitas descobertas e aprendizagens foram se constituindo, demonstrando que aprender não tem idade, basta ter acesso e oportunidade. A forma de documentação da memória dos projetos de trabalho desenvolvidos junto às crianças e divulgados para a comunidade, chama muito a atenção de uma das famílias , que diz:

"Mas, voltando para minha fonte de inspiração, quando vi aquelas pastas com fotos, não me lembro exatamente do que, acho que eram de alguns passeios das crianças, fiquei encantada. Aí pensei: é desta forma que vou organizar as fotos tiradas aqui na creche."

A comunidade, inspirada na organização documentária da Creche, busca cultivar a memória, materializando momentos significativos que os filhos vivenciaram na Infância. A apropriação da cultura por parte de uma das crianças causa grande espanto em sua família:

"Quando Jorge estava no berçário gostava de algumas histórias, mas o que mais chamou nossa atenção neste período foi o fato de lembrar o nome dos autores."

Em casa, uma das crianças descobre a diferença entre dois suportes de informação, quando ouve a história de Harry Potter, lida por sua mãe:

"Após o primeiro capítulo, uma noite meu filho mais velho disse, mãe essa parte não tem no filme, então o livro tem 
partes que os filmes não mostram? Sim, eu disse, os filmes são baseados nos livros, só que 2 horas de filme não dá para mostrar tudo, por isso os autores têm que resumir."

A criança, ao descobrir a diferença, sente necessidade de compartilhar suas descobertas dos suportes de informação com os colegas da Creche. Marcas de dedos nas páginas dos livros demonstram o desejo de compreensão daquele emaranhado de letras:

"O livro voltou bastante folhado, os dedinhos marcados em várias páginas. Olhei para o livro feliz, eles ainda não sabem ler, pensei, como é que ficaram folhando um livro no qual somente tem letras?"

A contribuição de livros e fitas de vídeo trazidos pelos pais para ampliar o acervo da Oficina de Informação é um outro marco do reconhecimento da importância desse ambiente na Creche:

"É claro que a opção por contribuir com o acervo da Oficina de Informação foi baseado na constatação de quão importância é este projeto: a ânsia das crianças em subir para aquele espaço para escolher livros e fitas de vídeo era evidente."

Um dos depoimentos revela preocupação e desejo desse tipo de trabalho com todas as crianças:

"Que todas as crianças pudessem ter a oportunidade desse contado com a Oficina de Informação." 


\section{- Adolescentes}

Cristina saiu da Creche Oeste no ano de 1996, atualmente cursa a $8^{\underline{a}}$ série do ensino fundamental II, no Colégio Giordano Bruno e tem 15 anos.

"Pelo que eu me lembre da biblioteca da Creche Oeste, íamos lá, algumas vezes para a professora ler algum livro, e mais tarde, nos deixava pegar livro pra ver lá, ou levá-los para casa. Eu lembro que o primeiro livro que peguei pra levar pra casa foi "Cenouras Frescas e Pãezinhos Quentes". Nós podiamos também pegar vídeo cassete para assisti-los em casa, eu os pegava apenas quando iamos para a casa da minha vó (que era o único lugar onde iamos, e tinha televisão). Além disso, eu lembro que tinha vários gibis da Turma da Mônica, e eu adorava lê-los (e ainda o faço). Na verdade, só me lembro dessas coisas, e outras, mas aconteceram fora da biblioteca, e acho que isso não teria utilidade para você..."

Cristina

S.P, novembro de 2004

\section{$* * *$}

Gustavo Henrique Cantisani Finotti, freqüentou a Creche Oeste, no período de 1990 a 1995. Atualmente, cursa o $1^{\circ}$ Ano do Ensino Médio da Escola Vera Cruz, e tem 16 anos.

"Já faz alguns anos, oito para ser mais exato, que não sou mais aluno da Creche Oeste. Porém, minha memória de adolescente ainda me permite recordar alguns momentos do meu período na creche; e que momentos... 
A ida à OFIN no final de cada dia na creche era sempre um momento gostoso descontraído. Era raro existir alguém que não quisesse ir à OFIN no final das tardes, se é que me lembro bem. Eu, particularmente, gostava de deitar nos confortáveis "puffs" estampados para assistir aos filmes que eram colocados pelas educadoras. Elas sempre sugeriam uma olhada nos livros das estantes para que levássemos algum, mas eu sempre ia direto para os "puffs" torcendo para que o meu pai se atrasasse para vir me buscar. E esse era o momento que mais me entristecia: a hora de ir embora. E ele sempre chegava cedo, "sempre na melhor hora do filme". Ainda por cima, nós sempre tínhamos que ir embora, pois ele nunca podia esperar.

Lembro me também, do mural com fotos que era renovado a cada ano, se minha memória não me falha. Cada um tinha a sua, em tese, devia ser a melhor foto da família, ou uma das melhores. Eu, como toda criança ingênua e boba (no bom sentido, é claro) E esse era o momento que mais me entristecia: a hora de ir embora. E ele sempre chegava cedo, "sempre na melhor hora do filme". Ainda por cima, nós sempre tínhamos que ir embora, pois ele nunca podia esperar (na verdade, eu não gosto até hoje). Embora todas as educadoras gostassem de repetir que eu era muito fotogênico e que meu irmão Matheus, hoje com 9 anos, fosse minha cópia perfeita, eu sempre procurava desviar o olhar da minha foto. Mas, não era tão ruim assim: eu acabava até me acostumando com a idéia do mural, até porque todos tinham suas fotos expostas. $O$ mais engraçado era que cada um falava da foto do colega, ora caçoando, ora apenas vivendo mais um momento de descontração dos dias na creche. 
Por fim, posso dizer que a escola, nessa fase da infância de uma criança, não passa de uma etapa, recheada de alegria e diversão, no aprendizado das mesmas, mas que, contudo, significou uma fase importante e essencial da minha vida escolar assim como na de todas as outras crianças. É com base nisso que gostaria de terminar expressando a minha profunda tristeza em saber que parte das crianças, e uma parte significativa delas, não desfruta dessa passagem em suas infâncias, um momento único e tão pessoal na vida de cada uma delas, não importando cor, raça ou nacionalidade."

Gustavo

S.P, de dezembro de 2004

Os dois depoimentos de adolescentes que passaram uma parte de suas infâncias na Creche/Pré Escola Oeste, revelam que a Oficina de Informação deixou marcas significativas na memória de cada um. Isto pode ser observado a partir de alguns indicadores:

A lembrança do primeiro título escolhido para compartilhar com a família:

"Eu lembro que o primeiro livro que peguei pra levar pra casa foi "Cenouras Frescas e Pãezinhos Quentes".

A única possibilidade de assistir a vídeos junto à família:

"Nós podíamos também pegar vídeo cassete para assistilos em casa, eu os pegava apenas quando íamos para a casa minha vó (que era o único lugar onde íamos, e tinha televisão)." 
A iniciação da leitura dos gibis da Turma da Mônica na Oficina , levada para a vida:

"eu lembro que tinha vários gibis da Turma da Mônica, e eu adorava lê-los (e ainda o faço)"

A forte imagem dos elementos que compõem o ambiente da Oficina de Informação:

"Eu, particularmente, gostava de deitar nos confortáveis "puffs" estampados para assistir aos filmes que eram colocados pelas educadoras"

A vontade de "esticar" o tempo de permanência na Creche e poder assistir ao filme até o final se faz presente na memória deste adolescente:

"E esse era o momento que mais me entristecia: a hora de ir embora. E ele sempre chegava cedo, "sempre na melhor hora do filme". Ainda por cima, nós sempre tínhamos que ir embora, pois ele nunca podia esperar."

Com a ajuda dos amigos, a superação da dificuldade em se perceber exposto no painel de fotos:

"Mas, não era tão ruim assim: eu acabava até me acostumando com a idéia do mural, até porque todos tinham suas fotos expostas."

Além dessas memórias, um dos depoimentos revela a preocupação com questões políticas e sociais, a percepção de que nem todas crianças tiveram a oportunidade de viver experiências tão significativas e intensas no período de suas infâncias:

"É com base nisso que gostaria de terminar expressando a minha profunda tristeza em saber que parte das crianças, e uma parte significativa delas, não desfruta dessa 
passagem em suas infâncias, um momento único e tão pessoal na vida de cada uma delas, não importando cor, raça ou nacionalidade."

\section{2 - Depoimentos de pesquisadores}

Adriana Cerqueira, em 2002 participou do projeto da Oficina de Informação como bolsista, faz parte do quadro de educadores da Creche/ Pré Escola Oeste.

"Iniciei meu trabalho na Oficina de Informação como educadora da creche Oeste em 1998 e em 1999 como bolsista do CNPq. Participar do processo de pesquisa foi fundamental para minha formação de educadora, pois ampliou o meu olhar sobre a compreensão da Educação Infantil. Porque é um ambiente que propicia além do código escrito a leitura de mundo. A junção entre PROESI - Programa Serviços de informação em Educação e a Coseas - Coordenadoria de Saúde e Assistência Social - Divisão de creches possibilitou a realização deste projeto. Este se constituiu num espaço de construção de cultura, expressão, comunicação e resignificação de seu repertório simbólico, contribuindo para o processo de aprendizagem e desenvolvimento de todos os envolvidos, como crianças, pais e funcionários. Na Oficina de Informação, o momento mais apreciado era contar histórias, pois observar o brilho nos olhos das crianças, contemplar as expressões de alegria, tristeza e espanto ao dizer "... Era uma vez..." tornava esse momento único. Abria-se então a porta para o mundo mágico as crianças ficavam encantadas com a fada e sua varinha mágica, ou com medo da bruxa má e seu caldeirão ou entusiasmados com a coragem e a inteligência do menino ao enfrentar o gigante. Ao final da história falar "... Entrou por uma porta e saiu pela outra... "é imprescindível para ouvir : conta 
de novo! Enfim, considero na Creche Oeste, a Oficina de Informação um espaço lúdico importante que contribui para o desenvolvimento da criança na Educação Infantil."

Adriana

S.P, Novembro de 2004

$$
* * *
$$

Toninha, participou como supervisora das bolsistas na Creche/Pré Escola de 1995 a 2000.

"Em janeiro de 1995, aceitando convite do Prof. Edmir Perrotti para coordenar as atividades do espaço laboratorial do Projeto - Oficina de Informação - eu não poderia imaginar que o início de uma nova fase como educadora, após o término de uma carreira de 26 anos junto a escolas da Rede Estadual de Ensino do Estado de São Paulo, me abriria um mundo de novas aprendizagens e relações de amizade, tão intensas, que dariam novos significados às minhas experiências de vida tanto profissionais como pessoais. Penetrar numa instituição de educação infantil, não como supervisora de ensino, mas como pesquisadora, mudou o eixo de minha atuação profissional de tantos anos como especialista em educação. Na Oficina de Informação eu entrei para observar e aprender, mais do que para exercer uma função. Nunca eu havia trabalhado diretamente com crianças na faixa etária de atendimento da Creche Oeste de 3 meses a 6 anos e meio. Como professora de classes de alfabetização (1 ${ }^{a}$. série do ensino fundamental) eu já tivera experiência com crianças a partir de 6 anos e meio. 
O entusiasmo era total e o envolvimento numa estrutura de relações hierárquicas se me apresentava num outro viés: ali eu não estava subjugada à direção, todavia dependia de decisões da equipe de direção e coordenação, para desenvolver atividades constantes do Projeto, como reuniões com as educadoras e comunidade, visita às salas de aula, atendimento a grupos de alunos para visitas programadas à Oficina, etc..

Como toda inserção num novo grupo de profissionais, a situação implicava certas reservas, de ambas as partes, numa afirmação de competências $e$ habilidades, para alargar ou fechar limites nas relações. Eu me percebia como uma intrusa a ser vigiada, por vezes isolada no andar de cima da Oficina de Informação, como numa "torre da Rapunzel". Os primeiros contatos e reuniões foram bem formais, com olhares cruzados e "territórios" demarcados: eu sentia uma barreira que me impedia a espontaneidade para opinar, perguntar, me entrosar. Embora mobilizando sentimentos doloridos de minha própria história de vida, eu sabia que todo esse período de adaptação era previsível e normal.

Aos poucos, as relações davam sinal de uma confiança e aceitação na forma de realizar minhas atividades. Os primeiros resultados do Projeto, reforçados com a mediação do Prof. Edmir Perrotti nos encaminhamentos da pesquisa, mais as trocas com as "bolsistas de iniciação científica", foram permitindo novos vínculos e aproximações. Eu já me sentia, então, mais livre para circular nos espaços da Creche, para dialogar com as crianças, que diferentemente das implicações dos adultos, me recebiam no mesmo ritmo da minha empolgação. 
Tinha dias que eu me sentia tão feliz, só faltando falar sozinha, naquela pequena sala povoada de bichos de pano e um acervo de livros infantis (além dos cds e fitas de vídeo) que me permitia leituras de encantamento e magia. Eu queria dar conta de todos os contos, de todas as poesias, para depois programar atividades de interação com as crianças, por vezes me atrasando nos afazeres rotineiros de organização e conservação dos materiais.

Dessa rotina de atividades, nos quatro primeiros anos de freqüência diária e nos dois anos subseqüientes em que comecei o período de transição para um desligamento progressivo, mantendo um acompanhamento em forma de assessoria que possibilitasse a apropriação do Projeto pela própria instituição, muitas lembranças ficaram registradas. As mais especiais ou significativas me vêm, neste momento, da confiança que o coordenador do Projeto, Prof. Edmir, sempre demonstrou na minha atuação. Também as muitas reuniões e cursos de formação que me levaram ao embasamento científico das propostas em experimentação, acrescentando informações e elaboração de conhecimento no tocante às questões de desenvolvimento do potencial da criança para a comunicação e as relações com a informação e a leitura.

Trocar experiências com as bolsistas, coordenando as ações planejadas ao mesmo tempo de uma vivência conjunta dessas ações foi, também, muito produtivo tanto para a formação desse pessoal, como para mim, na medida em que interagia com pessoas recém saídas da Universidade, ou ainda concluindo cursos em diferentes áreas do conhecimento. Isso possibilitava renovação de antigos procedimentos ou posturas. 
Com a equipe da Creche Oeste, em especial com a Coordenadora Pedagógica, Rose Mara, e com a Diretora na ocasião, Marie Claire, pude perceber a habilidade necessária para se dar conta de um cronograma de atividades programado em minúcias, dada a complexidade de fatores intervenientes, exigindo uma flexibilidade e visão ampla dos objetivos e da programação anual a ser cumprida. Por conta do ritmo intenso em que toda a instituição se vê movida, com as crianças "crescendo" a cada minuto em todos os sentidos, um certo desencontro se dava com o ritmo de desenvolvimento da pesquisa que ali desenvolvíamos. Esta requeria muita observação e reflexão para tomada de decisões no desenrolar dos procedimentos que inquietava a todos os envolvidos, tanto pesquisadores como profissionais da instituição. Só o tempo deu conta, creio eu, da assimilação de informações exigidas para o bom termo da pesquisa, que, aliás, não tem um fim delimitado, dado que ela dá margem a novas e progressivas questões a serem pesquisadas.

Voltando às lembranças vivas na minha mente, me vejo falando com as crianças por meio do boneco "Ofin", criado por inspiração da exigência de uma delas, mesmo, quando disse que só o "Ofin", cuja imagem aparecia nos recados e mensagens trocados com a comunidade, não era de verdade como os "bichos" de pano da Oficina. Embarcando nesse imaginário que a tudo dava vida real, criamos uma relação com afetividade e ludicidade, realizando ritos marcantes, como nos aniversários do Ofin, comemorados nas datas referentes à inauguração e reinauguração da Oficina de Informação. A história do Soldadinho de Chumbo, contada com a intervenção de duas educadoras encarnando os personagens principais, bem como episódios do Sítio da Emília, do Lobato, revividos com a atuação de educadoras, bolsistas e até de funcionários da 
Creche, numa dessas comemorações, ficaram na minha memória de tal forma que integram as imagens que revivo a cada contação dessas histórias.

Ter tido, também, a experiência de coordenar as publicações bimestrais do Boletim OFINFORMA, com a supervisão do Prof. Edmir, foi algo muito especial para mim. O boletim materializava, naquelas comunicações escritas e nas ilustrações das crianças, não só as experiências vividas por conta da Oficina de Informação, mas, ainda, muito do dinamismo e entusiasmo que permeavam todas as nossas ações e expectativas.

Permanecer um período grande nesse espaço laboratorial, numa instituição bem estruturada do ponto de vista pedagógico e de coordenação, acompanhada pela orientação e formação constante junto ao Prof. Edmir, deu-me experiência e convicção nos fundamentos norteadores do Projeto, além de respaldo para atuar nos programas de formação e reciclagem de professores das escolas municipais de São Bernardo do Campo, entre outros, bem como de profissionais que atuam nas bibliotecas municipais de São Paulo. A cada projeção do vídeo "Aventura de Conhecer", elaborado sobre a Oficina de Informação, eu revivo essa experiência e retomo o entusiasmo com essa nova concepção de biblioteca interativa, para passá-lo aos educadores e profissionais hoje em ação nos espaços de leitura.

Claro que eu não poderia deixar de mencionar a incrivel experiência que tivemos no estágio efetuado no ano de 1998, em bibliotecas francesas, convivendo por 10 dias com outros bolsistas do PROESI (Programa Serviços de Informação em Educação), incluindo a participação de educadores da própria 
Creche Oeste. Considero ter sido essa uma oportunidade ímpar na minha vida, bem como acredito ter sido para os demais integrantes do grupo, que contribuiu para alargar o horizonte de perspectivas e formas de atuar com a informação e a leitura, junto a crianças e jovens."

Toninha

SP, dezembro de 2004

\section{***}

Waldomiro Vergueiro, é Professor Associado do Departamento de Biblioteconomia, da Escola de Comunicações e Artes - USP.

"Durante alguns anos, tive a oportunidade de exercer a coordenação do projeto Oficina de Informação junto ao PROESI, grupo de pesquisa ligado ao Departamento de Biblioteconomia e Documentação da ECA-USP. Como pesquisador desse Núcleo de Pesquisas, responsável por esse projeto específico, cabia-me zelar para que os objetivos estipulados para o projeto fossem seguidos em sua implementação, não se afastando ele do proposto pela equipe coordenadora do PROESI (da qual, à época, eu fazia parte, juntamente com a professora Regina Obata e o Prof. Edmir Perrotti).

Instalado na Creche-Oeste da USP, tratava-se de um projeto de pesquisa com uma vertente muito forte de intervenção social $e$ isso fazia dele uma experiência ao mesmo tempo fascinante e desafiadora. Mais do que qualquer dos projetos desenvolvidos pelo PROESI, a Oficina de Informação representou um compromisso com a mudança de uma situação estabelecida e aparentemente 
institucionalizada no país: o afastamento das novas gerações do mundo da leitura, fruto de políticas equivocadas de construção de biblioteca, da falta de uma estratégia ou mesmo de uma filosofia que guiasse a familiarização das crianças com o mundo dos livros e da informação. Nesse sentido, a proposta do projeto buscava estar à frente das barreiras que a educação institucionalizada criava em relação à leitura, envolvendo à em um manto de obrigações. $\mathrm{Na}$ proposta da Oficina, o contato da criança com a informação deveria ocorrer de forma prazerosa, sem imposições, sem verificações, sem cobranças, explorando sua curiosidade natural, sua afetividade e seu estágio de desenvolvimento intelectual. Era uma proposta inovadora, que buscava a criação de um ambiente diferenciado de relacionamento da criança com a informação, explorando meios e formas de tornar o mundo da leitura também o da inclusão, envolvendo todos os participantes na mesma busca de autonomia.

Quando comecei a participar mais ativamente da Oficina, ela já era um projeto totalmente estabelecido. Sendo o primeiro a ser desenvolvido pelo PROESI, aplainou, por isso mesmo, alguns trajetos epistemológicos, que foram depois trilhados com muito maior tranqüilidade pelos projetos que the seguiram. $A$ partir da Oficina foram estabelecidos os eixos básicos de intervenção do grupo de pesquisa, que funcionaram como guias aos projetos seguintes. $\mathrm{Na}$ Oficina foram definidas as estratégias de intervenção que sofreriam adaptações e adequações para aplicação a outros públicos (o estudante de primeiro grau, na Escola Interativa, e o idoso, na Estação Memória). Na Oficina afloraram as primeiras interrogações sobre o processo de intervenção, que possibilitaram a correção de rumos e a definição de objetivos mais bem delineados. Principalmente pela Oficina se conseguiu o apoio do grupo de 
pesquisadores franceses que possibilitou tantos avanços ao PROESI, maravilhados pela relação criança/informação que ali se estabelecia.

Nos anos que estive à frente - ou, melhor dizendo, ao lado do projeto Oficina de Informação, caminhando com ele -, pude perceber que seus bons resultados se deviam a uma série de fatores, não necessariamente fortuitos, que congregava todos aqueles que nele estavam envolvidos. Eu os resumiria basicamente em três: um ambiente, uma comunidade e uma paixão:

a) um ambiente: a Creche-Oeste da USP reunia todas as condições para aplicação do projeto. Já existia na instituição um ambiente que privilegiava elementos como a autonomia da criança, a exploração da afetividade e a participação da comunidade nas atividades institucionais. Pode-se dizer que a criação de um espaço específico para a discussão e aprimoramento de questões informacionais não apenas veio ao encontro da cultura organizacional predominante naquela instituição, mas, muito mais que isso, complementou $e$ ampliou as preocupações que ali predominavam. Ao se criar a Oficina naquele espaço, não houve agressões à cultura, à forma de ver o trabalho de intervenção e mediação que a creche executava. Além disso, juntamente com a direção da Creche, houve o cuidado, durante a instauração do processo, de negociar com a comunidade o melhor local de instalação e fazer com que ela participasse de sua instalação, assumindo-o como seu. Isso aconteceu em função do ambiente predominante, mas, também, por características da própria comunidade, como discuto a seguir. 
b) uma comunidade: a Creche-Oeste constituía uma comunidade bastante coesa, que respondia de forma entusiástica, ainda que não necessariamente homogênea, às convocações ou propostas de sua diretoria para o desenvolvimento de novas atividades. Embora apresentando as mesmas dificuldades de entrosamento de qualquer agrupamento humano formal, o corpo de funcionários atuava de forma coesa, entendendo suas atividades como partes de um projeto maior e que, em última instância, englobava o desenvolvimento de uma postura ativa da criança em relação à vida. Eram todos parceiros em uma proposta na qual acreditavam e não apenas simples trabalhadores que tinham aquele trabalho como forma de manutenção pessoal e familiar. Vários deles, inclusive, além de funcionários, tinham na Creche também os seus próprios filhos, tendo que desempenhar ao mesmo tempo o papel de educador e de mãe, desta forma compreendendo a importância dessa etapa de convivência institucional na vida da criança. O estabelecimento da Oficina de Informação contou, ainda, com o apoio direto dos pais e familiares, que também acompanhavam o trajeto da criança no mundo da informação (e, ao acompanha-la, ampliavam o seu próprio contato com recursos informacionais e com o mundo da leitura, redescobrindo novas maneiras de relacionamento com o mundo da palavra escrita e da leitura).

c) uma paixão: por trás da idéia da Oficina de Informação estava uma proposta capaz de entusiasmar de forma incondicional a todos que nela se envolviam. Talvez poucos outros projetos em informação e educação no país tenham ousado mirar tão longe quanto esse projeto, propondo a ampliação do relacionamento infantil com a informação de uma forma que não chegava a ferir o seu mundo, mas, pelo contrário, o integrava de forma tranqüila e 
efetiva, ao mesmo tempo em que, a partir dessa intervenção, criava condições para a constituição de um novo modelo de cidadão. E isso acontecia pelo próprio conceito de informação embutido no projeto, que ia além do mundo dos livros armazenados no espaço, dos filmes a que as crianças assistiam durante as visitas, às revistas que manuseavam, mas, muito mais que isso, incorporava as produções das próprias crianças e do seu mundo familiar. Nesse espaço institucional, o acervo deixava de ser apenas o que se comprava ou recebia por doação, mas passava a ser também aquilo que as próprias crianças elaboravam, seja em espaço de classe, para qualquer objetivo - um desenho comemorativo, uma narrativa gráfica, o desenvolvimento de algum projeto criativo, etc. -, como na sua própria casa - como as fotos da família, do aniversário, dos amiguinhos, do seu animal de estimação, entre outras coisas. Tudo isso fazia com que a Oficina de Informação representasse um elemento de convivência e criação a assumir cada vez mais importância no mundo da criança. Era não apenas o momento de quebra da rotina, o passeio em direção a um outro espaço de permanência, mas a introdução em um espaço meio mágico, no qual as atividades nem sempre seguiam uma rotina previamente estabelecida. Nesse sentido, as estratégias criadas para transformar a Oficina em muito mais que um espaço para o armazenamento de alguns materiais impressos levaram ao estabelecimento de uma arquitetura específica, um mobiliário especialmente preparado e a disposição dos materiais de forma a propiciar o fácil entrosamento das crianças no e com o mundo da informação. Além disso, contemplavam também um planejamento de atividades que buscava envolver plenamente as crianças, ampliando seu entusiasmo e participação. $E$, por outro lado, tampouco descuidava da preparação das educadoras, criando formas de participação nos treinamentos e encontros, que ocorriam periodicamente na 
Creche. Neste último aspecto, a Oficina foi bastante afortunada por contar com a participação de uma pessoa bastante dinâmica na organização das atividades, a Toninha, uma pessoa preparada e com larga experiência na área de educação, que, juntamente com os diversos estagiários que participaram do projeto, se esmerava em um permanente processo de aprimoramento das atividades, buscando sempre novas atividades, avaliando os resultados obtidos, questionando os educadores sobre formas de ampliar os efeitos das atividades da Oficina, abrindo-se a sugestões e incorporando novas idéias a cada momento. Tudo isto fez da Oficina uma experiência difícil de comparação com qualquer outro empreendimento educacional.

Minha participação na Oficina ligou-se muito mais a aspectos estratégicos. Como mencionado, cabia-me zelar para que as atividades desenvolvidas não se afastassem da linha-mestra do projeto, reforçando sempre os pilares estabelecidos para ele. É claro que essa atividade de planejamento não deixava de considerar e incorporar minha participação em algumas atividades práticas, principalmente quando de sua introdução, e também acompanhar todos os visitantes ao espaço, esclarecendo os objetivos e a filosofia de criação da Oficina. Tive, inclusive, a oportunidade de participar da realização de alguns encontros comemorativos, como a festa de aniversário da Oficina ou a celebração de algumas datas especiais, organizada pela Creche, em que a Oficina participava de alguma maneira. Em todo o período de acompanhamento, tive um contato permanente com a direção da Creche, principalmente com a diretora e com a coordenadora pedagógica, com quem sempre tive um relacionamento bastante amigável e de permanente colaboração. Não me 
lembro de desencontros, de desentendimentos, ou mesmo de atividades que não tenham atingido os objetivos pretendidos.

Parece-me que a Oficina conseguiu ser totalmente incorporada na cultura da Creche-Oeste, passando a representar um de seus maiores trunfos. Considero um privilégio ter participado da construção desse espaço e espero e me orgulho muito do que consegui ali construir, embora talvez a colaboração que dei não chegue a representar muito em todo o processo."

Waldomiro Vergueiro

S. P, fevereiro de 2005

$* * *$

Cíntia Shukusawa Kanashiro, participou como Bolsista de 1995 a 1997.

\section{A OFICINA DE INFORMAÇÃO EM MINHA VIDA}

"Autonomia, diversidade cultural, afetividade, ludicidade, sociabilidade. Essas palavras vêm forte à minha mente até hoje. Na ocasião do encaminhamento da pesquisa, em meados de 1996, eram os principais conceitos de que se ocupava um dos projetos-piloto do PROESI, a Oficina de Informação.

Não são apenas esses conceitos que ficaram em minha lembrança. Carreguei comigo, vida afora, as belas e ricas experiências que lá obtive.

Lembro-me do alvoroço das crianças nos dias em que se dirigiam à Oficina, seja para um momento de leitura, seja para retirar livros, assistir a filmes, 
participar das rodas de histórias, visitar os personagens daquele espaço (Ofin, Taru, macaco Kiko). Foram muitas vivências naquele lugar lúdico e mágico, permeado pelo sorriso das crianças e o esforço das educadoras em tentar conter tamanha energia, imaginação e fantasia...

Claro que não poderia deixar de mencionar, de meu lado, a confecção do boletim da Oficina de Informação - o Ofinforma. Foi uma experiência bastante gratificante por envolver o exercício da concepção editorial específica a um projeto, o processo de edição, o trabalho com o texto e a criatividade. Conceber o projeto final do boletim (foram mais de duas versões!), definir as seções, a pauta, coordenar as ilustrações das crianças, escanear os livros, fazer as reportagens, ter contato com as atividades nos módulos (G1, G2, G3... G6), conhecer mais de perto a realidade das crianças e dos educadores... Ufa! Quanta coisa gostosa de fazer e de aprender. E também, quanto esforço para chegar a um bom trabalho, um boletim de acordo com as concepções do projeto Oficina como um todo.

Foi difícil sair desse projeto e partir para o mundo, para as empresas, onde encontramos, em geral, uma realidade bem diferente, norteada por outros tipos de pressupostos e até de valores.

Mas, ao enfrentar o mercado de trabalho, pude perceber o quanto a Oficina de Informação havia sido um marco em minha vida e o quanto me influenciou - eu diria, me qualificou. Ter passado por essa experiência junto à Oficina mudou totalmente a minha visão do mundo. Passei a ter uma postura diferente em relação ao trabalho, à vida. 
Em termos profissionais, trabalhando com a edição de livros didáticos $e$ formação de professores, por exemplo, pude notar uma preocupação constante de minha parte em fazer um trabalho sério, verdadeiramente envolvido com as causas escolares, apesar das grandes corporações, muitas vezes, priorizarem os prazos, os lucros e a linha de produção - no âmbito da indústria cultural, massificada.

Mesmo assim, por influência de minha passagem por projetos como os do PROESI, sempre procurei, na medida do possivel, resistir às pressões corporativas de prazos e lucros, a fim de prezar a qualidade. Em minha trajetória profissional, pude perceber, cada vez mais, o envolvimento e o comprometimento com a educação, a ética e os projetos de qualidade. A tentativa e a esperança de levar para as salas de aula o melhor material possivel, dentro das limitações existentes na produção. Buscar a excelência nos projetos, mas sem que isso fosse visto como perfeccionismo, detalhismo. Não. É a excelência que se busca para ficar acima da mediocridade e atingir o mais alto potencial possível, o vôo sublime. Como já disse um autor, é a busca da excelência como "material de que se faz a grandeza", o que torna o trabalho muito mais significativo.

Outra questão que posso comentar se refere a um dos objetivos de caracterização da Oficina - concebida com um espaço de "difusão de conhecimentos científicos e tecnológicos, visando ao desenvolvimento do espírito científico da criança". Creio que isso não só repercutiu nas crianças e na comunidade da Creche mas também nos próprios participantes do projeto. 
Ter atuado num projeto desse nível ampliou o meu interesse por questões de educação, cultura, ciência e tecnologia, além de me direcionar mais profundamente a pressupostos teórico-metodológicos que norteiam qualquer trabalho. Em meus projetos editoriais, por exemplo, sempre levei em conta esses fatores; sempre tive a preocupação de verificar a fundamentação e a consistência da obra, coleção, manual do professor... Procuro levar aos livros a mesma preocupação existente naqueles projetos-piloto, em relação à fundamentação e ao embasamento teórico/prático/metodológico.

Cito um outro exemplo: Ao fazer os manuais da coleção didática, destinados ao professor, sempre tive a intenção de valorizar a formação de educadores, oferecendo-lhes subsídios teóricos e metodológicos significativos para contribuir com a prática pedagógica. E uma das preocupações da Oficina era exatamente a formação do educador/mediador, qualquer que fosse o espaço educativo em questão.

A Oficina, na medida em que visava à difusão de conhecimentos artísticos para desenvolver a sensibilidade estética e a imaginação da criança, formou a mim mesma nesse sentido. Passei a valorizar, em minha vida, a Arte $e$ desenvolvimento da sensibilidade estética.

Foi fantástico perceber que absorvi e levei comigo os pressupostos que caracterizam a Oficina de Informação, no trabalho, na Arte, na vida.

A proposta de criar um serviço referencial, com a perspectiva de sua multiplicação em diferentes espaços educativos, fez com que eu aprendesse a 
valorizar as ações culturais e educacionais como um todo, especialmente em comunidades que não têm acesso a esses bens, em comunidades carentes de recursos e estrutura.

E daí despertou-se em mim a vontade de fazer mais, de lutar por ideais e projetos que favoreçam a inclusão, a igualdade social e a pluralidade cultural.

Todo ser humano, para viver com dignidade, precisa de fato conquistar a autonomia, conhecer e vivenciar a diversidade cultural, desenvolver a afetividade, a ludicidade e a sociabilidade. Precisa sobretudo ter a capacidade de ser o protagonista de sua própria vida, de escrever a própria história.

Enfim, posso afirmar que ter passado pela Oficina deu-me um brilho especial aos olhos, à alma. Foi uma oportunidade ímpar de conviver com a grandeza de um projeto, de conhecer diversas pessoas e histórias. $E$ perceber que são esses projetos que influenciam e reformam poderosamente o mundo. Que contribuem para formar verdadeiros artistas da vida, valentes, lutadores de um mundo melhor, sementes de um novo amanhã. $E$ assim é possivel ter esperança, fé na vida, crença de que tudo pode ser melhor e de que ainda temos muito a fazer..."

\section{Cíntia}

S.P, março de 2005 
Linice da Silva Jorge, Doutoranda pela área de Psicologia e Educação da FEUSP, participa do PROESI desde a sua constituição.

\section{MEMÓRIAS DA OFICINA DE INFORMAÇÃO}

O primeiro espaço onde desenvolvi e apliquei a pesquisa de campo de mestrado, Roda de Histórias ${ }^{27}$ foi a Oficina de Informação ${ }^{28}$, na Creche-Oeste/USP, em 1998.

Este espaço laboratorial foi fruto de um projeto de pesquisa - PROESI Programa Serviço de Informação em Educação, em convênio com o COSEAS/USP, criado e coordenado pelo Professor Dr. Edmir Perrotti - do qual participei desde o início (1993), junto a um grupo de pesquisadores, bolsistas e professores de diferentes áreas - acompanhando todo o seu processo, desde a construção de conceitos e metodologias de implantação até a aplicação da Roda de Histórias em 1998.

$\mathrm{Na}$ época, foram realizados inúmeros encontros, reuniões de planejamentos, discussões e estudos criteriosos junto ao coordenador na busca e elaboração de concepções, teorias e práticas, tendo em vista a implementação de uma nova concepção de serviço de Informação em educação para crianças.

\footnotetext{
27 JORGE, Linice da Silva. Roda de Histórias: sons, imagens e movimentos - novos modos de informação em educação. Dissertação de Mestrado, ECA/USP, 1999, sob a orientação do Professor Edmir Perrotti da Escola de Comunicações e Artes da USP.

${ }_{28}$ Espaço laboratorial criado pela equipe do PROESI - Programa Serviços de Informação em Educação da ECA/USP em convênio com COSEAS/USP, cujo grupo de pesquisa foi constituído e coordenado pelo professor Dr. Edmir Perrotti CBD/ECA/USP em 1993.
} 
A instalação deste espaço exigia a mediação e o diálogo constante e cuidadoso do coordenador e equipe com os membros da Creche-Oeste. Era preciso estabelecer acordos e limites respeitando-se os princípios e objetivos do Projeto, bem como, o ritmo, a dinâmica, as exigências e as programações da Creche. Surgiram assim as negociações, resistências, constrangimentos, conflitos, preocupações que facilitavam ou dificultavam o avanço do mesmo.

Até então eu não podia imaginar que a preparação daquele simples espaço, relativamente pequeno, traria experiências tão amplas, ricas e significativas para minha vida, tornando-se uma verdadeira fonte de conhecimentos e de prazer nas relações de trocas sociais, culturais e educacionais com as pessoas envolvidas no processo. Assim, tenho a grata satisfação de rememorar a construção gradativa do espaço, do nosso desempenho, na luta árdua $e$ apaixonada para transformá-lo num ambiente bonito, lúdico, aconchegante e ao mesmo tempo funcional, adequado e significativo para a criança.

O espaço reservado para a Oficina de Informação, antes utilizado como depósito de materiais da Creche, passou a ser o foco principal de nossas atenções. Envolvidos e preocupados com a inserção dos produtos no local, pensávamos em todos os detalhes para sua implantação, desde a limpeza e arrumação, até o design geral de configuração do ambiente. $O$ mobiliário precisava apresentar uma linguagem que dialogasse com outras linguagens, criando uma rede de relações e sentidos. Assim, decidiu-se aos poucos a forma $e$ a posição dos armários, a quantidade e localização dos livros infantis, a criação de objetos, materiais ou recursos lúdicos como painéis, almofadas, caixas coloridas, móbiles, fantoches, cortinas, entre outros. 
Seiscentos livros de Literatura Infantil foram organizados e classificados por gênero, com fitas adesivas - azuis, amarelas, vermelhas $e$ verdes - $e$ colocados nas caixas correspondentes às cores, para facilitar o seu acesso, escolha e reposição dos mesmos no local. Outros foram apoiados sobre um trilho de cortina anexado na parede e expostos de maneira que as crianças pudessem alcançá-los e visualizar suas capas $e$ ilustrações. Foram confeccionados painéis lúdicos de histórias, com diversas ilustrações e almofadas de pano coloridas quadradas ou no formato de grandes animais uma cobra, um sapo e uma tartaruga - planejados para exercer diversas funções, ora como suportes para as crianças sentarem-se, ora como recursos narrativos etc. Depois de prontos os móveis, os recursos técnicos e lúdicos interagiam entre si formando no ambiente a síntese entre 0 real e 0 simbólico, estimulando o afloramento do imaginário e a fantasia das crianças.

Lembro-me com emoção, do olhar de encantamento e alegria das crianças ao entrarem pela primeira vez neste novo espaço que se inaugurava. Reconheciam suas próprias fotos ali expostas e pegavam os livros em suas mãos folheando e olhando curiosas as imagens e histórias ali existentes. Tocavam deslumbradas em tudo que viam, nas figuras dos painéis: árvores, borboletas, Saci Pererê entre outros. Aos poucos iam aconchegando-se nas almofadas coloridas para ouvirem as histórias e brincadeiras que preparamos para recepcioná-las. Atentas e com olhos arregalados escutavam as histórias sobre a cobra e o sapo que tinham saído do bosque para ficarem naquele local encantado, ouvindo também as narrativas junto aos seus novos amigos. Compreenderam que os livros tinham suas casinhas coloridas (caixas) para 
morar e que precisavam ao entardecer, voltar para as caixas para descansarem à noite. Após a primeira inauguração, estagiários, bolsistas e pesquisadores acompanharam a apropriação das crianças no espaço e sua relação com os recursos ali existentes.

Mais tarde, um novo momento inaugural festejava a entrada de um novo mobiliário mais aperfeiçoado, completando o espaço com novos armários, computador, aparelho de som, Cds, fitas e um trenzinho de madeira, substituindo as caixas coloridas. Seus vagões traziam faixas de cor $e$ abertura na parte superior, servindo de suporte para a colocação dos livros. Os vagões com rodas móveis podiam ser deslocados de um lado para outro.

Este espaço, assim preparado, foi o berço sobre o qual apliquei a proposta metodológica Roda de Histórias com crianças - pesquisa de mestrado que eu vinha desenvolvendo paralelamente a este processo - buscando referências teóricas e operacionais necessárias para sua aplicação no espaço. Nele encontrei os elementos (instrumentos ou dispositivos) necessários e compatíveis com as práticas narrativas, podendo trabalhar diversas linguagens, relacionando-as e cruzando-as entre si, tornando possível as trocas intersemióticas propostas na Roda. Desta forma a pesquisa foi realizada entre março e agosto de 1998 e incluiu encontros fundamentais com a Coordenadora Rose Mara e educadoras da creche para obtenção de informações, organização de horários dos grupos de crianças e momentos de atividades relacionadas com a Roda de Histórias. Nestes encontros tanto a Diretora na época, Marie Claire, Coordenadora da Creche e educadoras sempre atenderam prontamente minhas solicitações, acompanhando o meu 
processo de atuação com as crianças de forma participativa e interessada. Assim permaneci na Oficina de Informação durante seis meses com as crianças de 3 a 6 anos e meio, de ambos os sexos, formando grupos separados pelas mesmas faixas etárias, totalizando 71 crianças de nível sócio-cultural heterogêneo.

A minha experiência na Roda de Histórias com as crianças no espaço foi produtiva, gratificante e prazerosa. O desejo de ouvir histórias e a curiosidade pelas novidades ou surpresas do momento atraía muito o público infantil. À medida que as crianças se apropriavam da Roda e se organizam no espaço de forma circular sobre as almofadas, envolviam-se cada vez mais com as histórias e modificavam seu modo de agir, percebendo que podiam ouvir e também falar ou contar suas histórias. Diferente da hora do conto, a Roda intercambiava histórias entre os pequenos narradores estimulando o narrar e escutar de cada um. Tal dinâmica consistiu num conjunto de sensibilizações, que nasceram através das linguagens oral, sonora, visual, gestual e escrita (desenhos). Assim explorei a oralidade por meio das histórias de ficção, recursos lúdicos, livros etc., utilizando-me de acordo com o momento, dos sons, imagens e movimentos, que auxiliaram na descontração paulatina dos envolvidos. A fala e a escuta sensível conduziram a criança para uma "escuta de si e do outro" - uma forma de se auto-educar. Criou-se um clima lúdico e descontraído, mas ao mesmo tempo educativo e informativo, possibilitando criar formas de socialização que estimulassem a afetividade, a ludicidade, a diversidade e a autonomia da criança. Segundo depoimentos de algumas educadoras, as crianças faziam questão de recontar as histórias que tinham ouvido na Roda solicitando às educadoras que as escutassem. $O$ interesse pelos 
livros também foi crescente, e foram muito utilizados e solicitados pelas crianças. Quanto às ilustrações, estas permitiam que as crianças fizessem relações com outras imagens, desenhando, criando e recriando histórias. A extensão do texto em livros - longo ou curto - não representou dificuldade para elas no acompanhamento ou "leitura" das histórias até o final.

Quanto aos recursos lúdicos além daqueles existentes no espaço, criei para a pesquisa outros recursos narrativos como o avental lúdico, o biombo mágico, a caixa lúdica e o tapete de histórias, os quais foram utilizados amplamente. Assim as crianças se envolviam, apropriando-se das histórias e do espaço aproximando-se, interagindo e compreendendo o sentido da Roda e das relações que podiam estabelecer entre si e com espaço intersemiótico. A Roda na sua dinâmica interagiu, despolarizou narradores e mobilizou crianças, pais e educadoras.

Dado o envolvimento das crianças e os vínculos construídos, estendemos a proposta, além do tempo previsto pela pesquisa, trabalhando também com grupos compostos de crianças com faixas etárias diferentes, no horário de ateliê dos mesmos. Tal decisão deveu-se ao próprio interesse despertado pelo trabalho da creche. A participação intensa das crianças na Roda de Histórias, ampliando suas capacidades de expressão e comunicação, trouxe resultados positivos, constatados por mim e através de depoimentos dados pelos professores, coordenadores, pais e pelas próprias crianças da creche. E assim nasceu a Roda de Histórias. 
Participar do Projeto Oficina de Informação e da Pesquisa Roda de Histórias despertou em mim um novo olhar sobre a pesquisa científica permitindo-me compreender um pouco mais sobre as complexas e difíceis relações metódicas e sistemáticas que se constroem e se articulam entre teoria e prática e sobre as relações e vínculos interpessoais que se estabelecem com crianças, comunidade educadores, pais no processo da pesquisa no seio de uma instituição.

A construção desse espaço Oficina de Informação, na Creche-Oeste representou um grande avanço para a instituição e para a Educação, trazendo perspectivas e concepções educacionais inovadoras. Ao criar este novo instrumento ou dispositivo informacional em educação infantil, o Projeto possibilitou a produção, difusão e recepção de informações e cultura para a criança, oferecendo a elas e aos usuários condições necessárias, para que estes pudessem freqüentá-lo de maneira descontraída e interessada, explorando com liberdade os recursos ali existentes como livros, vídeos, CDs, brinquedos, jogos e outros, além de permitir a escolha e retirada dos mesmos, visando o desenvolvimento do espírito crítico e científico de cada um. Além disso, o espaço atuou com toda a comunidade educativa, desenvolvendo atividades de informação e cultura, abertas a públicos externos à instituição, possibilitando também o encontro de criadores de cultura em geral, permitindo a difusão de conhecimentos científicos. Daí a importância dos espaços interativos de Informação nas instituições de Educação.

Por isso, nada supera o prazer de saber que muitos objetivos foram alcançados e que o espaço segue suas metas e o seu destino. Hoje, sou grata pela 
oportunidade de ter sido convidada pelo Professor Dr. Edmir Perrotti para participar da construção desse Projeto que vi nascer e se tornar palco de muitas oficinas na pesquisa Roda de Histórias, prática narrativa, transformadora e significativa que me conduziu a outros patamares no campo das relações e do conhecimento, levando-me à realização de sonhos $e$ concretização de ações pedagógicas satisfatórias, além de me trazer novas perspectivas de vida profissional e de relacionamento educacional, intelectual e humano."

Linice Jorge

SP, abril de 2005

\section{$* * *$}

Edmir Perrotti, é Prof. Dr. do Departamento de Biblioteconomia, da Escola de Comunicações e Artes - USP

A Margarete, aluna do curso de Biblioteconomia que trabalhava na Creche Central da COSEAS, teve o insight: as creches da USP não possuem bibliotecas! Parece que sabia que nós - eu e um grupo de colegas do Departamento e de fora da ECA - havíamos criado um programa de pesquisas, destinado ao estudo e desenvolvimento de novos Serviços de Informação em Educação, o PROESI. Falou com a Profa. Regina, que naquela época pertencia ao grupo e de quem frequentava a disciplina. Foi encaminhada a mim, coordenador do Programa. Falou de suas preocupações e, quem sabe, da possibilidade de uma parceria com as creches da USP. 
Como desejássemos constituir um ambiente de informação em situação concreta, a fim de sistematizarmos referências científicas fundamentais à Educação do país, fomos falar com a Yara, então diretora geral das Creches da COSEAS/USP. Mulher de visão larga e de decisão, ela percebeu de imediato a importância do projeto e da cooperação. Consultou sua equipe e procurou-nos dias depois, propondo a Creche Oeste como espaço para a implantação da «Oficina de Informação» - o nome foi decidido em conjunto, numa reunião nossa com a Yara e a equipe da COSEAS, com as primeiras discussões já em andamento.

Que me lembre, a Divisão de Creches optou pela Creche Oeste pela necessidade de redefinição do trabalho pedagógico nessa unidade, que estaria passando por várias dificuldades, decorrentes de sua história. Pretendia a Divisão que houvesse mudança de rumos, requalificação dos serviços fundamentais prestados à comunidade da Universidade. A Oficina seria um passo essencial rumo aos novos caminhos a serem tomados pela Creche Oeste. E acertou!

Para fazer a interlocução da Creche com os pesquisadores, foram indicados pela Divisão dois membros da equipe de supervisão pedagógica das Creches: a Consolação e a Márcia.

Era pretensão inicial da proposta- até hoje, infelizmente, não concretizada- a extensão do projeto para todas as creches, da USP, após a implantação na Oeste. As duas supervisoras poderiam, com a experiência da primeira implantação, acompanhar o projeto Oficina de Informação nas outras unidades 
de Educação Infantil então existentes nos campi da USP. As supervisoras passaram, pois, a integrar a equipe de planejamento e implantação do projeto, introduzindo-nos no terreno, ao mesmo tempo em que eram introduzidas em questões teóricas e metodológicas próprias da pesquisa.

«Deus põe e os homens dispõem », diz o ditado. Daí que a prévia e necessária definição das posições e acordos não garantiu mares permanentemente serenos, entre as muitas partes envolvidas no projeto. Todavia, especialmente em processos complexos - se é que existem processos humanos simples! - não se deve ficar amedrontado com tal fato. Há muitos elementos em jogo e, quando o sonho é grande e o desejo forte, a agitação das águas é intensa. Mas ela é também densa e consistente. COSEAS, Divisão de Creche, Creche Oeste, ECA, Pesquisadores, Administração Geral da Universidade, quantas vidas, temperamentos, paixões, vontades! Algumas conscientes, outras nem tanto, outras ainda impossíveis de serem explicitadas. Dizia, contudo, o poeta, navegar é preciso, viver, não é preciso. Desse modo, se o desconhecido assusta, impele; se produz resistências, provoca adesões e descobertas; se paralisa e separa; entusiasma e reúne, com seus portais voltados ao infinito.

Por isso, com marinheiros muito, pouco ou nada experientes, içamos velas e lançamo-nos ao mar. Direção: um magnífico objetivo comum, as novas possibilidades de relações de crianças com o conhecimento e a cultura, a Oficina de Informação.

Constuma-se dizer que os pequeninos ficam maravilhados com histórias de príncipes, bruxas e feiticeiras, de fadas, bichos e duendes. Passados dez anos, 
olhando as propostas e as realizações dessa construção a várias mãos, longe de ser criança, não há como não ficar encantado com a vida, quando embalada por ritmos criativos; não há como permanecer insensivel diante de lembranças como a da moça Pedra Margarete me procurando para falar de seu lampejo lúcido. Jovens querendo um mundo mais bonito, mais humano, mais sensível e inteligível. Que alegria!

Nunca esqueci da véspera da inauguração da Oficina. Ficou pronta no último dia, lá pelas sete ou oito da noite. Eu, a Márcia, a Linice - minha orientanda, preparando na época sua dissertação de Mestrado sobre as Rodas de Histórias, com crianças que freqüentariam o espaço. Ah, havia o guarda, na portaria. Ninguém mais na Creche. Sentados no chão, em silêncio, olhávamos e sorvíamos o sonho objetivado em livros, revistas, CDs, vídeos, fotos, painéis, almofadas, TV. Era novembro, um móbile com motivo natalino, pendendo do teto, movimentava-se e preenchia o vazio com sua dança lenta, plena de cores e reflexos. Lembro que, de repente, vislumbrei um violão, surgido não sei até hoje de onde. Não resisti. Quando jovem, aprendi uns poucos acordes. Quem sabe fosse preparação para o momento! Dei o tom, cantamos baixinho, como convém a certas celebrações:

Se essa rua, se essa rua fosse minha, eu mandava, eu mandava ladrilhar, com pedrinhas, com pedrinhas de brilhante...

Era assim que o trabalho tinha sido feito. A equipe cuidava-ao menos pretendíamos- da Oficina como se lapidasse brilhantes. Que as crianças, como garimpeiros de boa sorte, pudessem encontrar as mais belas e preciosas pepitas naquele lugar. Que pudessem construir anéis, colares e braceletes 
deslumbrantes com suas imaginações, inteligências e sensibilidades. Que pudessem produzir jóias que não são visíveis em sua essência, mas que nos movem e constituem: conhecimento e cultura.

Felizmente, a Oficina não foi feita somente de promessas e esperanças. Desde que abriu as suas portas, realizou a máxima barthesiana: o saber com sabor. Ali, num movimento vibrante, ininterrupto e vivo, significados circulam, são produzidos, construídos e reconstruídos; ali, sujeitos constituem e se constituem, sempre em festa, com muita alegria, numa indicação de que vale à pena indagar, refletir, questionar, abraçar uma idéia, um amigo, uma criança, um adulto. Afinal, os perigos existem não só nas histórias e a solidariedade é condição para enfrentá-los. Compartilhar lobos, chapeuzinhos, lenhadores e vovós é forma de resistência e de pertencimento. E a Oficina oferece, desde que abriu, tal possibilidade às crianças: a construção de si e a conquista da alteridade.

É fantástico lembrar do menino que descobriu um livro sobre o Monet, encantou-se e acabou fazendo com que toda a Creche se mobilizasse $e$ organizasse uma ida ao Museu de Arte de São Paulo, o MASP, onde uma exposição sobre o impressionista francês era um enorme sucesso. Muitas crianças jamais haviam saído de seu próprio bairro. A descoberta proporcionada pela Oficina permitiu que atravessassem fronteiras que não eram só geográficas, mas sociais e culturais.

E aquele garoto, de origem japonesa! Trouxe uma fita-cassete com músicas orientais para dividir suas raízes com os colegas. A partir da iniciativa, criou-se 
também toda uma programação na Creche, tendo o Japão como referência. Ao mesmo tempo, instituiu-se um novo padrão na ordem cultural estabelecida: não só a Oficina iria emprestar livros e outros materiais às crianças; elas emprestariam também à Oficina, enriquecendo seus acervos e as possibilidades de leitura de todos, num vai-e-vem salutar e cidadão de produtos culturais. Novos vínculos entre as crianças e o novo espaço; novos vínculos entre Creche e Casa e vice-versa. O conhecimento como reconhecimento, identificação, pertencimento. Um país mestiço encontrando-se, trocando, comunicando, construindo-se na e pela Oficina.

E aqueles dois meninos que se trancaram na Oficina! Não queriam sair dali, não queriam ir para outro lugar da Creche. Passaram a chave na porta. Foram necessárias longas negociações para que abrissem e atendessem súplicas de pais, mães e educadores atônitos com tanta paixão. Um desses dias, encontrei um deles, já rapaz, e sua mãe numa livraria da cidade. Tinham ido ao lançamento de um livro. Ele estava totalmente feliz e à vontade no habitat. Era íntimo. Que sorte a minha, encontrar o André ali (acho que é esse seu nome, como o do meu pai). Como diz um outro poeta : a bêncão, menino, moço, signo!

Não pesquisamos apenas. Vivemos, compartilhamos, navegamos na Oficina de Informação... Que as naus possam sempre prosseguir no mar. A invenção constitui, acalenta e conforta. Eternos navegantes, dela necessitamos, seja sob a forma de ciência, de arte, de filosofia ou dos saberes da experiência.

Edmir Perrotti

S.P, junho de 2005 
Os depoimentos dos pesquisadores revelam que é possível estabelecer parcerias entre pesquisa e serviço no contexto educacional.

O reconhecimento do terreno fértil que é a Creche Oeste aparece no depoimento de um dos pesquisadores:

"a Creche-Oeste da USP reunia todas as condições para aplicação do projeto. Já existia na instituição um ambiente que privilegiava elementos como a autonomia da criança, a exploração da afetividade e a participação da comunidade nas atividades institucionais. Pode-se dizer que a criação de um espaço específico para a discussão e aprimoramento de questões informacionais não apenas veio ao encontro da cultura organizacional predominante naquela instituição, mas, muito mais que isso, complementou $e$ ampliou as preocupações que ali predominavam."

A oportunidade de participação no projeto da Oficina de Informação mostrou novos caminhos e possibilidades de atuação na Educação:

"Penetrar numa instituição de educação infantil, não como supervisora de ensino, mas como pesquisadora, mudou o eixo de minha atuação profissional de tantos anos como especialista em educação."

Uma das pesquisadoras demonstra no seu depoimento o envolvimento, compromisso e a emoção de participar do projeto:

"Tinha dias que eu me sentia tão feliz, só faltando falar sozinha, naquela pequena sala povoada de bichos de pano e um acervo de livros infantis (além dos cds e fitas de vídeo ) que me permitia leituras de encantamento e magia. Eu queria dar conta de todos os contos, de todas as 
poesias, para depois programar atividades de interação com as crianças..."

Inicialmente, houve estranhamentos entre as equipes do PROESI e da Creche, como demonstra o seguinte depoimento :

"Os primeiros contatos e reuniões foram bem formais, com olhares cruzados e "territórios" demarcados: eu sentia uma barreira que me impedia a espontaneidade para opinar, perguntar, me entrosar."

Apesar de alguns descompassos entre as equipes, havia algo em comum, motivando a parceria:

"Eram todos parceiros em uma proposta na qual acreditavam e não apenas simples trabalhadores que tinham aquele trabalho como forma de manutenção pessoal e familiar."

As comemorações ou celebrações, ora promovidas pela Creche, ora pela Oficina de Informação, possibilitaram a quebra da hierarquia entre as equipes (Creche e PROESI) e dentro da própria Creche, como mostra um dos depoimentos:

"...realizando ritos marcantes, como nos aniversários da Oficina, comemorados nas datas referentes à inauguração e reinauguração da Oficina de Informação. A história do Soldadinho de Chumbo, contada com a intervenção de duas educadoras encarnando os personagens principais, bem como episódios do Sítio da Emília, do Lobato, revividos com a atuação de educadoras, bolsistas e até de funcionários da Creche, numa dessas comemorações, ficaram na minha memória de tal forma que integram as imagens que revivo a cada contação dessas histórias." 
O boletim Ofinforma marca o investimento da equipe do PROESI em integrar a Oficina de Informação à proposta pedagógica da Creche, possibilitando que todos segmentos tivessem vez e voz no processo de apropriação.

"Claro que não poderia deixar de mencionar, de meu lado, a confecção do boletim da Oficina de Informação - o Ofinforma. Foi uma experiência bastante gratificante por envolver o exercício da concepção editorial específica a um projeto, o processo de edição, o trabalho com o texto $e$ a criatividade. Conceber o projeto final do boletim (foram mais de duas versões!), definir as seções, a pauta, coordenar as ilustrações das crianças, escanear os livros, fazer as reportagens, ter contato com as atividades nos módulos (G1, G2, G3... G6), conhecer mais de perto a realidade das crianças e dos educadores... Ufa!"

\section{3 - Depoimentos de Funcionários}

\section{- Educadoras}

Valéria, participou do quadro de funcionários da Creche Oeste, como educadora e coordenadora de módulo de 1994 a 2003

\section{UMA EXPERIÊNCIA QUE LEVO NOS NOVOS DESAFIOS PROFISSIONAIS}

"A implantação da Oficina de Informação (Biblioteca Interativa) foi desde a primeira reunião com Edmir Perrotti e as educadoras, até a inauguração, um espaço cheio de dúvidas, ansiedades, um lugar que necessitaria estar em constantes mudanças. Algumas perguntas me marcaram muito e hoje escrevendo este depoimento, acredito que conseguimos ao longo dos anos, respondê-las. Como por exemplo: 
- Quem vai cuidar do espaço?:

- É difícil entender as classificações dos livros;

- Precisamos ter uma quantidade grande de livros, pois iremos emprestálos;

- Vão ter muitas pessoas usando, e se rasgar os livros?

Várias reuniões aconteceram e tudo parecia muito complicado, a sensação era: Não vamos dar conta!

No dia da inauguração, fizemos um coquetel com presenças ilustres, sabíamos que seria um grande desafio, mas a equipe da Creche estava disposta a enfrentá-lo.

Pudemos, aos poucos, compreender e responder para nós mesmos, algumas dúvidas. Percebemos que livros são para ser lidos, usados e aparecer algumas vezes rasgados (tínhamos que agüentar ...) Inauguramos a Oficina de Informação com uma quantidade muito boa de livros, onde podíamos emprestá-los para cada sala, para casa e ainda ter bastante disponível na $O$ ficina de Informação. Enfim dúvidas, ansiedades, aos poucos e com muita conversa, foram sendo esclarecidas.

Um problema que foi aparecendo: a organização do espaço. Todos funcionários, educadores e crianças tinham que se conscientizar sobre o problema: o significado do espaço coletivo. Por muitas reuniões a pauta era: organização da Oficina. Foram conversas cansativas, mas a transformação só acontece com muito esforço coletivo e com o tempo. 
Muitas pessoas passaram pela Oficina, no início quem era responsável pelo espaço, eram as bolsistas da Eca, pessoas que deixaram sua marca. Lembro-me da Cíntia, com seus "Ofin Informa" (boletim informativo),entrevistava pais, crianças, educadoras, sempre destacando alguns grupos, seus trabalhos e livros favoritos.

$E$ as histórias da Toninha algumas longas...mas contadas com um grande prazer, ela fazia daquele momento único na sua vida. Tem uma história que não me lembro o nome, mas era de um menino e seu cavalo de madeira, que linda! Conto hoje para meus filhos. Ela junto com a Linice, criaram o mascote da Oficina, o Ofin, um fantoche que contava histórias, e participava das rodas de conversas nas salas.

Penso na Linice, e logo imagino a cobra, a tartaruga, e o sapo, personagens importantes na Oficina de Informação, muitas vezes pareciam criar vida nesse lugar. Penso nos momentos que vivi, as histórias que contei, deitada ou sentada em um desses personagens.

Bom...chegou a hora de andarmos com as próprias pernas. Não teríamos mais bolsistas da ECA e a presença do Edmir e Toninha não seria mais constante, também se passaram 2 anos, é chegada a hora de enfrentar o novo, apesar de fazer parte da nossa rotina.

Cada ano, uma educadora da Creche ficaria responsável pelo espaço, planejaria junto com a educadora de cada grupo atividades, enfim seria a forma de 
conhecer realmente o espaço e conviver com todas as crianças da Creche, pois passariam por ali todos os grupo. Foi nesse rodízio que fiquei responsável pela Oficina, e pude aprender uma lição que jamais esquecerei...

Foi em um encontro da Rose Mara, pedagoga da Creche e a Márcia, educadora da Creche Central, que também desenvolvia um trabalho na comunidade São Remo.

A Rose Mara, pensou em realizar um trabalho com essas crianças, para que elas pudessem usar esse espaço, já que não era um privilegio das nossas crianças, mas sim um direito, não estávamos sendo "boazinhas" seria uma extensão da Oficina de Informação - Creche Oeste para a comunidade São Remo .

Marcamos o primeiro encontro, recebemos as crianças com um lanche no pátio da árvore, chegaram bem ansiosos, queriam conhecer todo o espaço. Levamos eles até o tanque de areia e percebemos que as crianças do $G 6$ estavam curiosas em saber quem eles eram, alguns até se conheciam, pois moravam na mesma comunidade.

Foi então que fizemos uma grande roda no pátio coberto, onde todos puderam se conhecer. Em seguida, fomos até a Oficina, mais uma vez a descoberta, o novo, a exploração falo mais alto. Ler uma história, pedir para relaxar e se concentrar, seria impossível. Quando foram embora, ficamos com a sensação de que fizemos a coisa certa, tinha que ser assim... mas teríamos que pensar, planejar. 
Nos encontros seguintes as crianças do $G 6$ participaram da organização do espaço do lanche, comiam juntos com as crianças, trocariam assim experiências. A ida à Oficina foi ficando mais tranqüila, conversávamos, pude contar histórias, escolhiam livros que levariam para a escola e desenhavam.

Nos convidaram para conhecer a escola, marcamos o dia e fomos com o $G 6$ até lá. Nos recebemos como "grandes convidados" conhecemos o espaço onde brincavam, estudavam e o canto da leitura... quantos livros... pensaram na organização, comida e até fizeram uma carta para o G6. Algumas crianças saíram de lá falando: que legal ! uma escola só para eles !!!! Esses encontros duraram o ano todo e pode ser estendido para o ano seguinte.

Que lugar é esse onde me deixou tantas lembranças e experiências ricas para minha vida. É um lugar pequeno... chamado Oficina de Informação, lá na Creche Oeste. Não consigo pensar na Oficina sem usar a emoção, não dá para ser racional, teórica, a Oficina é o coração da Creche.

Hoje no meu novo trabalho fui chamada para ajudar na organização da Biblioteca do Fundamental I (1 a 4 séries) que coincidência, coisa do destino...fui dando idéias, contando minhas experiências vividas na Creche, e hoje olho para esse espaço e vejo a extensão da Oficina de Informação.

Quando chego em casa e meus filhos correm para o quarto aonde tem um canto de leitura (com a Deitalê, a cobra que a vovó fez para eles) e me pedem para contar histórias, paro e penso... foi na Creche Oeste que me foi despertando o 
amor pelos livros, pelas histórias de Literatura Infantil. Vejo meus filhos apaixonados pelas histórias que aprendi a gostar na Oficina de Informação."

Valéria

S. P, dezembro de 2004

$* * *$

Marionice, faz parte do quadro de educadores da Creche/Pré Escola Oeste desde 1995.

"Após algum tempo trabalhando com grupos de crianças, fui contemplada a estar na Oficina como "educadora da Oficina". Confesso que, no começo, fiquei um pouco receosa, com medo de não corresponder à importância que esse local tem dentro da Creche-Oeste, mas, ao poucos, no seu dia-a-dia, pude perceber como este universo era e é "rico" de informações e quanto conhecimento e experiências únicas poderiam ser extraídas para toda minha vida profissional.

Os grupos de crianças ou de educadores e pesquisadores que visitam este espaço contribuem para torná-lo encantador, cheio de vida. É um ambiente que forma $e$ informa ao mesmo tempo, proporcionando, assim, a construção de saberes que interagem entre si para formação da bagagem cultural de cada um, tornando-os cidadãos críticos numa sociedade em constante mudança. O que é muito interessante é que mesmo estando dentro da Creche-Oeste, a Oficina também é um espaço aberto à comunidade. As crianças do "Centro Educacional Girasso/'29 puderam usufruir, por algumas vezes, deste espaço através das

\footnotetext{
${ }^{29}$ Esclarecemos que a Escola Alô a Alô mudou seu nome para Centro Educacional Girassol.
} 
histórias narradas, de vídeos, fotos, objetos e empréstimos de livros, assim como, interagir com as crianças do $G 6$ que sempre as recepcionavam com um lanche e brincadeiras. Foi possivel observar como estes momentos foram prazerosos para elas, havia um brilho diferente em seus olhares e a despedida ficava sempre com um gostinho de quero mais. Provavelmente, muito poderia se dizer dela, mas é um espaço dinâmico, que fala por si só, e cada um terá um modo para descrevê-la e para guardá-la em sua memória."

Marionice

S. $P$, fevereiro de 2005

$* * *$

Mariana, exerceu a função de educadora, e também Coordenadora de Módulo, fez parte do quadro de funcionários de 1995 a 2000.

"Minha relação com a Oficina sempre foi de muito prazer, adorava acompanhar o grupo de crianças lá e contar histórias para elas, vê-las manusear os livros, era uma ambiente tão lúdico, tão especial.

Antes da reforma, achava as caixas coloridas (nas quais os livros eram acomodados) muito atrativas aos olhos das crianças, após a reforma então nem se fala,tudo pensado para a criança, o olhar voltado para a criança, móveis, almofadões, caixas em formato de trem para os livros.

O fato dos livros estarem ao alcance das crianças desmistifica a nobreza/elitização do objeto "livro" já que, aos olhos de muitos as crianças não podem pegar, manusear os livros pois, sendo "crianças"não tem 
capacidade, cuidado, e os livros seriam rasgados, danificados. o adulto, este sim, por ser adulto tem condições de manusear o livro sem danificá-lo. A Oficina põe abaixo esta idéia, acredita na criança acredita que a criança produz e consome cultura.

$\mathrm{Na}$ Oficina facilmente nos transportávamos para o universo mágico retratado nos livros.

Lembro de uma ocasião em que a Toninha contava uma história sobre uma Fênix renascendo das cinzas com uma bola no bico...; da Rosana (educadora) brincando de borboleta com as crianças ao som da música da Marisa Monte "...eu sou uma borboleta pequenina e feiticeira..." (e as crianças rindo); do Felipe Altimeyer (na época criança do G2) pedindo para contar a história do Batmão; do Edmir (em reunião na ECA falando sobre afalta de políticas públicas e a importância de se apoiar essas ações isoladas; da Taru; das crianças sentadas na cobra; olhando as fotos no mural; do Élye contando para nós a história "Pedro e Tina uma amizade muito especial"; Especial como foi a Oficina (e tudo o que eu vivi com relação a ela) na construção da minha história", pessoal e profissional, na construção da "história da minha vida"...

Mariana

S. P, outubro de 2004 
Kamila Rumi Toyofuki, educadora participou da proposta pedagógica Creche Oeste de 2001 a 2004.

\section{PEQUENOS DETALHES QUE FAZEM UMA GRANDE DIFERENÇA} "Ler...

Nunca gostei de ler, sempre li por obrigação, obrigação imposta pela escola, obrigação de fazer uma prova ao término da leitura. Durante toda a minha infância, só li para a escola. Em casa não havia, não se via o hábito da leitura, mesmo os jornais, meu pai os lia no seu trabalho. Histórias? Só as contadas oralmente, pela minha mãe e pela minha avó. Eu gostava mesmo é de ver televisão!

$\mathrm{Na}$ Escola, democraticamente, a professora sempre indicava pelo menos dois livros para que pudéssemos "escolher". A minha escolha era simples: o livro que eu leria deveria ter o maior número de ilustrações, o menor número de páginas e, se possível, letras grandes! Adquirido o livro, a primeira coisa que fazia era contar o número de páginas que teria que ler. Ler sempre foi uma tortura. Se não me engano, de todos os livros que "escolhi", só consegui chegar ao final de três ou quatro. As histórias eram muito mais interessantes quando recontadas pelos meus amigos rapidamente durante os intervalos, antes das provas. Talvez esse meu "gosto" pela leitura fez com que eu preferisse o caminho das ciências exatas e decidisse, aos quinze anos, fazer um curso técnico em processamento de dados para poder trabalhar com os computadores. Trabalhei no ramo da informática por três anos até me entediar da máquina, passar a me interessar pelas pessoas, chegar às ciências humanas e fazer o curso de pedagogia. 
Para quem não gostava de ler, o curso de pedagogia foi muito difícil no início, eu precisava ler textos e mais textos todos os dias. As provas e os trabalhos exigiam muito mais do que a "descrição dos personagens da história" como no ensino fundamental. Começar a trabalhar logo na área foi um fator que me ajudou muito nesse sentido, dessa vez eu me interessava pelas leituras oferecidas, pois de alguma maneira contribuíam para a reflexão da minha prática e para o meu desenvolvimento profissional, não serviam apenas para ter um bom desempenho nas provas, comecei a me interessar pelo "final da história".

Quando estava no terceiro ano da faculdade tive a oportunidade de estagiar na Creche e Pré-Escola Oeste da Coordenadoria de Assistência Social da Universidade de São Paulo. Trabalhei lá por aproximadamente três anos e meio, inicialmente como estagiária e posteriormente como funcionária efetiva, sempre exercendo a função de educadora.

Foi na Creche que tive a oportunidade de reconstruir a minha relação com 0 livro e aprender a ler por prazer, "simplesmente" para saber o final da história. Para mim, querer saber o final da história não era um desejo assim tão natural, tão espontâneo... o esforço que envolvia a leitura era muito maior e acabava com qualquer desejo, as lembranças eram amargas.

A primeira vez que entrei na Oficina de Informação pensei: Ah, aqui é a biblioteca das crianças! Que bonitinho! Tem almofadas! Que gostoso... Uma caixa de sapato encapada de branco com uma cruz vermelha, uma caixa de primeiros socorros com durex, tesoura... ?!?, "São para consertar os livros, 
Kamila", Ah... Nossa, tem televisão! Que legal, eu adorava ver TV quando era pequena... Mas com essa televisão aqui, será que as crianças se interessam pelos livros?".

A primeira vez que conduzi uma Roda de História na Creche fiquei espantada. Foi na primeira vez que substituí uma educadora que havia faltado. Era um grupo de crianças de cinco anos de idade. Assim que sentamos na roda, imediatamente as crianças selecionaram os livros que gostariam que eu lesse. Uns sentados, outros deitados, todos atentos a história. Li uns três ou quatro livros para eles naquele dia. Parecia mágica!

Os segredos dessa magia eu fui descobrindo aos poucos, durante o período que trabalhei na Creche, inicialmente substituindo alguns educadores, posteriormente acompanhando o meu próprio grupo.

O início foi de puro encantamento observando o movimento das crianças. Observando e vivenciando... Aprendi a contar histórias vendo os educadores contando histórias para as crianças. Vi crianças que não sabiam ler, "lendo" livros, do seu modo, sozinhas. Vi também crianças "lendo" livros umas para as outras. Vi crianças lendo enquanto outros brincavam no pátio. Vi crianças escolhendo o livro dentre diversas propostas oferecidas (jogos, artes e jogo simbólico). Vi o encantamento de uma criança de dois anos por um livro grande, grosso com letras pequenas! Vi crianças maiores escolhendo o mesmo livro grande, grosso com letras pequenas porque "tem mais histórias, Kamila!". Vi uma criança do pré, já alfabetizada, orgulhosa por poder ler uma história para 
mim. Vi também um bebê de um ano e meio pedir para que eu lesse uma história pra ele.

Nessa trajetória, trabalhar no G2, grupo das crianças de dois anos, depois de "ter visto tanta coisa" foi muito importante para compreender e apreender o trabalho realizado com a Oficina de Informação. No G2, tive a oportunidade de refletir com minhas parceiras de trabalho sobre o canto de leitura, sobre o a proposta da Oficina de Informação, sobre a melhor forma iniciar o processo de empréstimo de livros e fitas, de apresentar a Oficina aos pais e convidá-los a fazer uso desse espaço junto com seus filhos.

Depois do G2, tive a oportunidade de trabalhar no Berçário também. Trabalhar com crianças tão pequenas possibilitou-me refletir sobre a leitura de uma forma mais ampla, que vai além da decodificação das letras, refletir sobre a importância de se oferecer um ambiente alfabetizador e principalmente, sobre a relação que estabelecemos com a leitura através do objeto livro antes mesmo de aprender a ler convencionalmente. Acompanhando as crianças pequenas, pude observar o início da relação destas com os livros. Por serem tão pequenas dispensam as formalidades, no começo vão logo colocando o livro na boca, sentindo o seu gosto, o seu cheiro, a sua forma, vão se encantando pelas imagens e aos poucos vão se interessando pela história que está sendo contada pela educadora. Consertar os livros que foram rasgados também faz parte dessa relação, consertar é cuidar, é também saber reparar o erro de tê-lo danificado. O tempo de concentração deles é bem pequeno, como o meu era em relação à leitura, e assim, como educadora, fui descobrindo junto com as crianças, o prazer da leitura, afinal, era tão agradável e gratificante vê-los se 
interessar pelos livros que não tinha como não me interessar também. Aos poucos eles foram ficando mais tempo nas nossas rodas de história, e eu com os livros.

Saí da Creche há uns dois meses, atualmente trabalho com crianças de quatro anos de uma Escola Municipal de Educação Básica da Prefeitura de São Bernardo do Campo. Por ser uma escola localizada no centro do Município, apesar de ser pública, é uma escola com muitos materiais pedagógicos, brinquedos e livros. A primeira vez que entrei na biblioteca da escola ${ }^{30}$, logo percebi a falta que fazia a existência de uma pessoa para poder cuidar daquele espaço. Muitos livros rasgados, sem capa ou sem algumas páginas e ainda à disposição das crianças, junto com os livros que estavam em bom estado de uso. Uma das primeiras vezes que levei o meu grupo até lá foi a convite de uma professora que estava levando o seu grupo para assistir um filme no aparelho de DVD. Fomos ver o filme juntos. As crianças entraram e a professora foi logo avisando: "É para sentar no chão e não no 'sapo', porque vamos ver o filme! Sentem-se um ao lado do outro para que todos possam se acomodar". O "sapo" é na verdade uma grande almofada em forma de "sapo" que infelizmente não foi feito com um material adequado, é revestido com um tipo de plástico, assim, quando as crianças se acomodam nele faz barulho e ainda corre-se o risco de rasgar o material... Imediatamente lembrei-me das almofadas da Oficina de Informação. Eram grandes, coloridas, macias, de diversas formas, havia uma quantidade adequada para que todos pudessem se acomodar nelas. Ah, essas crianças iam adorar a "Cobra" e a "Tartaruga" da Oficina... Assim que as

\footnotetext{
${ }^{30}$ Apesar de pertencer a Rede Municipal de Ensino de São Bernardo do Campo, trata-se de uma escola que ainda não possui uma "Biblioteca Interativa", como outras do município, desenvolvidas em cooperação com a equipe do Pr.Dr. Edmir Perrotti.
} 
crianças se acomodaram, a professora convidou a me sentar numa das duas cadeiras de adulto que havia lá para uso exclusivo das professoras. O filme começou e uma criança que estava sentada perto dos livros resolve pegar um para folhear. Logo a professora chamou a sua atenção dizendo que não era momento de ver o livro, afinal, se outras crianças resolvessem pegar um livro também, faria muito barulho e atrapalharia quem estava assistindo o filme. Novamente a imagem da Oficina de Informação veio em minha mente, de fato esta biblioteca era muito pequena e organizada para se fazer uma atividade de cada vez.

A primeira vez que fui ver os livros da biblioteca fiquei encantada. Nossa, a biblioteca tinha ótimos livros! Ótimos livros mas...

Quando levei meus alunos para escolherem livros para levarem para casa, foi uma confusão. Como nem todos os livros estavam ao alcance das crianças, elas começaram a me pedir para pegar "aquele livro lá de cima"! Então eu começo perguntando: "É esse? Não? Então é esse?". Os mais ansiosos, logo pegaram "a cadeira da professora", subiram e pegaram sozinhos os livros que queriam. Imediatamente me lembrei das caixas coloridas onde são guardados os livros da Oficina. Nada é por acaso, não é? E a questão da classificação dos livros? Quando uma aluna me perguntou: "Onde está o livro da Pequena Sereia que eu vi outro dia?", tive que responder "Não faço a menor idéia, temos que procurar por toda a biblioteca". Existe ainda uma estante e uma prateleira, cheia de livros de poesia, científicos, literatura nacional e internacional, uma maravilha, curiosamente os livros pelos quais havia me encantado quando conheci o acervo da Biblioteca. Depois eu descobri que justamente aqueles livros não poderiam 
ser emprestados para as crianças, pois alguns custaram muito caro e eram para ser lidos em sala de aula, pela professora. Esses livros devem compor praticamente cinquienta por cento do acervo da biblioteca, são muitos livros que as crianças não podem ter acesso autonomamente.

A cada dia que passa trabalhando nessa nova escola, cada pequeno detalhe da Oficina de Informação e da Creche de modo geral, vai sendo ressignificado em minha mente, o que antes era tão natural ou óbvio, talvez por estar incorporado na rotina diária, hoje percebo que faz toda diferença quando se pensa numa educação de qualidade. Cada detalhe foi pensado, planejado, nada é como é ou está onde está por mero acaso, e tudo está constantemente sendo mudado, repensado para melhor atender as crianças.

Hoje, lembrando da Oficina de Informação, me vem em mente um momento o qual confesso que dava pouco valor em nossa rotina, afinal, eram os últimos minutos do dia, quando levávamos as crianças que ainda não tinham ido embora lá para a Oficina. Um dia em especial me vem à mente. Era, se não me engano, o dia do encerramento das Olimpíadas 2004, em Atenas, na Grécia. Estávamos no pátio, devia ser por volta das 17h45, muitos pais já haviam levado seus filhos e estávamos com poucas crianças. Um educador deu a idéia de irmos todos à Oficina e propôs ao grupo de não assistir a um filme dessa vez, mas ver a festa de encerramento das Olimpíadas. Todos concordaram e fomos à Oficina. Chegando lá, a TV foi sintonizada no canal aberto que estava transmitindo o evento, algumas crianças como sempre foram se acomodando nas almofadas $e$ outras aproveitaram para ver um livro, sentando-se próximo as caixas de madeira. Uns bebês ficaram nos colos das educadoras, folheando um livro ou 
vendo a TV, outros preferiram exploram as fotos expostas na parede; um bebê mais agitado, gostou da idéia de ficar vendo os animais (cavalo-marinho, siri, peixe porquinho...) que ficam em potes de vidro numa das prateleiras de um armário da Oficina. Não sei se isso aconteceu nesse mesmo dia, mas me lembro também de ver duas crianças do $G 3$ que gostavam muito de explorar o computador quando iam à Oficina no final da tarde. Nesse momento também, algumas crianças sentem o desejo de desenhar e para isso, os papéis e os potes com giz de cera, lápis e canetinha estão na estante sempre à disposição. Os pais continuavam a chegar para buscar seus filhos. Um deles chegou e pediu licença para pegar uma fita de vídeo para levar para casa, acho que era para assistir no final de semana, um outro, viu que estávamos assistindo festa de encerramento das Olimpíadas e disse: "Nossa, ainda está passando?", e logo se juntou a nós para assistir a grande festa que estava acontecendo na Grécia naquela mesma hora. Crianças, educadores e pais estavam encantados com 0 evento, todos que passavam por lá, ficavam por alguns minutos assistindo a festa.

Diferentemente das demais bibliotecas, onde o silêncio, a ordem e a disciplina imperam, na Oficina de Informação eu vi VIDA, um espaço criado para receber e acomodar pessoas e não livros. Se um livro está fora do lugar é porque ele foi lido, porque alguém passou por lá, e como muitas pessoas passam por lá, existe a educadora responsável por esse espaço. O silêncio precisa ser quebrado, afinal, como ficar quieto e não compartilhar com meu amigo uma história fantástica que encontrei? 
É, a Oficina de Informação é mais que uma "biblioteca bonitinha". Acredito que é um espaço que vai além de TER e OFERECER livros, revistas, gibis, filmes, CDs, fotos, televisão, computador, aparelho de som para as crianças. A Oficina não é só um espaço, mas parte de uma proposta de Educação. Pude ver e vivenciar uma proposta que se preocupar com a RELAÇÃO que o indivíduo estabelece com tudo aquilo que a Oficina oferece. É um espaço cuidadosamente criado para promover ENCONTROS, encontros entre pessoas e entre estas com o mundo por intermédio das diversas mídias (não sei se é o termo correto) que ele oferece. É uma proposta que é desfrutada não só pelas crianças, mas por toda a comunidade escolar. Como educadora, através da Oficina de Informação pude me reencontrar com o livro e me deparar com diversos princípios de uma educação de qualidade vistos na faculdade, como teoria, traduzidos em pequenos detalhes que compõe uma prática.

Kamila Rumi Toyofuki

São Bernardo, novembro de 2004

\section{$* * *$}

Rosi, educadora que participou do quadro de educadores da Creche/ Pré Escola Oeste até o ano de 1994.

"Já faz tempo. Mas lembro-me bem que naquela época houve uma movimentação gostosa na Creche Oeste, com todas as informações, novidades... Lembro bem das caixas de livros chegando e da euforia que causou, parecíamos crianças abrindo balas, presentes... queríamos saber quais e quantos livros haviam chegando, quais as novidades. Lembro também da equipe decorando o espaço, 
construindo cobras, tartarugas, almofadas em panos bem coloridos, com a preocupação em fazer um espaço bonito e aconchegante. Depois de toda esta movimentação, pensar o uso do espaço. Lembro também que às vezes procurávamos uma criança (depois que o espaço já estava em uso) e a primeira idéia que nos ocorria era procurar na Oficina, ao chegarmos lá encontrávamos a criança nos almofadões com livros, de pernas cruzadas, desfrutando deste espaço.

Me recordo também da primeira dormida que teve depois da inauguração, planejamos um horário para história e uma das educadoras (Teresa)se vestiu de bruxa e contou histórias na penumbra da Oficina, foi muito significativo. Todas estas vivências contribuíram para a minha vida profissional e pessoal sou muito grata a Creche Oeste por ter me proporcionado estas experiências as quais multipliquei de alguma forma nos espaços e com as pessoas com as quais me relacionei.

Espero que ajude, um abraço"

Rosi

S.P, dezembro de 2004

\section{$* * *$}

Cristiane Aparecida dos Santos de Faria compôs o quadro de educadores de 1999 a 2001.

"Ao rememorar o significado da Oficina de Informação no contexto da proposta pedagógica de Creche Oeste, penso que se configura como instância de (in) formação de crianças e educadores enquanto leitores e escritores, não apenas 
das palavras, mas do mundo. Desde o Berçário, na Creche Oeste, as crianças são estimuladas a amar os livros por meio da escuta diária de histórias e da leitura que fazem delas por si mesmas. Esta concepção de que os bebês lêem, surpreende no início os pais, assim como me surpreendeu quando comecei a trabalhar com este grupo. Mas é isto mesmo: o manuseio de livros, mesmo que de plástico ou de papelão, e a observação das imagens constitui leitura.Ao acompanhar o grupo do Berçário quando passaram pro G2, lembro-me que as crianças tinham muita facilidade para se concentrar na Roda de História e um repertório grande de livros conhecidos, o que encantou uma educadora recémchegada do Módulo II para trabalhar neste grupo comigo.

No $G 2$ as crianças começaram a freqüentar a Oficina, mas antes houve todo um processo de preparação e sensibilização. O Ofin, fantoche habitante ilustre da Oficina, foi à sala conversar com as crianças e convidá-las para emprestar livros. Foi grande a euforia! Então demos início à construção de um espaço mágico na sala para a colocação dos livros: a "Tenda dos Livros", feita com tules coloridos, bolsões de tecido na parede, tapete e almofadas.

Depois deste trabalho com o imaginário das crianças, fizemos nossa primeira visita à Oficina com o objetivo de emprestar livros para deixar na sala, mais especificamente, na "Tenda". Realizada uma roda explicativa na sala, fomos cantando pelo caminho para traduzir a alegria do momento. A escada, desafio que se mostrava grande, não assustou as pequenas crianças: subiram "de gatinho" e desceram "de bundinha". Após observar os livros nos caixotes dispostos em forma de trem e até folhear alguns, cada criança escolheu um livro, cujo título foi anotado junto com a data do empréstimo. Os livros 
emprestados eram muito apreciados especialmente nos momentos de Roda, de Ateliês e outros.

Então chegou o grande momento de emprestarem livros para levar para casa, o que supunha uma parceria com os pais. Para garantir esta parceria foi feita, no espaço da Oficina, uma Reunião de Sensibilização, na qual, depois da leitura do texto "Livro: a troca" de Lygia Bojunga Nunes, os pais foram motivados a evocar memórias acerca do contato com os livros na infância, o que despertou a emoção de vários, inclusive de educadoras. Ficou claro que a leitura é marcada pela "amorosidade" entre leitor e livro. Em seguida, houve uma partilha sobre a cultura desenvolvida na Creche no que diz respeito à importância da leitura. Os pais, incentivados a ler com e para as crianças, cavando um espaço para isso na rotina, compreenderam que deviam valorizar o fato de o livro se fazer mediador significativo na relação entre pais e filhos. Na sequiência, foi explicada a operacionalização dos empréstimos e os pais foram convidados a também se servir do acervo, anotando no caderno e devolvendo no bolsão na entrada da Creche. Por fim, foi feita uma Roda de História, na qual uma educadora leu um dos livros preferidos das crianças.

Neste mesmo dia, cada criança, na presença do pai ou da mãe, fez a primeira escolha de livro para levar para a casa. Assim criou-se um vínculo ainda mais afetivo com a situação, que foi marcada pela alegria e pelo brilho nos olhos de todos, como se pode constatar por meio de fotos.

Nas escolhas posteriores, sempre às sextas-feiras, a mesma alegria vinha à tona ao manusearem diferentes portadores de textos na Oficina, e algo de muito interessante acontecia: várias crianças escolhiam sempre os mesmos 
livros, pois por se tratarem de histórias conhecidas conseguiam fazer uma leitura de imagens mais ligada ao contexto real da história. As crianças acostumadas a escutar histórias lidas ou contadas por educadores e pais, iriam escutar com os olhos, por si próprias. Aos poucos, as crianças se lançavam ao desafio de novos livros, de histórias desconhecidas.

A Oficina de Informação, espaço mágico e aconchegante, proporciona o contato com o universo cultural que se apresenta e se oferece sob a forma de vídeos, fotos, revistas científicas, jornais, gibis e sobretudo livros, impulsionando a formação dos pequenos leitores.

Aos educadores e pais a Oficina promove uma aprendizagem fundamental: como ser mediador na relação criança-livro e como fazer do livro um mediador da ação educativa.

Dialeticamente, o espaço da Oficina se presta a reuniões de formação continuada dos educadores, nas quais se faz a leitura reflexiva da prática pedagógica, visando melhorá-la continuamente.

Pode-se concluir que esta instância de (in) formação de crianças e adultos mobiliza a leitura de si mesmo, do outro e do mundo, merecendo ser reproduzido em muitas outras instituições educativas para o bem das gerações futuras"

Cristiane

Taubaté,fevereiro de 2005 
Sonia Vitória, faz parte do quadro de educadores desde o ano de 1994.

"Posso dizer que assisti ao nascimento da Oficina de Informação, pois, comecei a trabalhar na Creche Oeste em 1994 e naquele tempo já percebi que havia algo de inovador e respeitoso no trabalho dessa instituição. Minha experiência pessoal e profissional de antes não havia me proporcionado ver a criança como alguém com vez e voz, como realmente uma cidadã. Por quê ? As escolas particulares, principalmente as que trabalhei, via e ainda muitas vêem, a criança como algo a ser lapidado, que não sabe nada, que precisa aprender o que os adultos têm a lhes ensinar, a infância é vista apenas como uma passagem e não como um ciclo da vida que tem suas próprias necessidades.

Antes da Oficina de Informação ser construída, a Creche já possuía a prática de oferecer às crianças um ambiente de comunicação através de rodas de história. Quem passeava pela Creche podia apreciar crianças lendo gibis sentadas num canto, ou então usando esse material como brinquedo para construir castelos e, também, fazia parte da rotina das educadoras ler livros na sala para seu grupo.

Havia um desejo por parte das educadoras e outras equipes de organizar melhor esse trabalho de leitura com as crianças e quando veio a proposta de termos um espaço que proporcionasse não somente livros, mas também outros meios de informação a idéia foi muito bem recebida por todos. Então, o Edmir Perrotti e toda a sua equipe passaram a fazer parte de nossa equipe durante 
muito tempo e assim começamos a ter um grande investimento em informação e formação.

Nós educadoras só tivemos a ganhar com esse investimento, pois, ampliamos através de várias formações continuadas, o nosso conhecimento sobre literatura, gibis e filmes infantis, passamos compreender cada vez mais o universo das crianças, por meio dessa comunicação, dessa troca de experiências pudemos modificar também muitas de nossas atitudes e adquirir uma postura mais sólida e profissional no trabalho junto às crianças.

Hoje a palavra democracia é muito falada por muitos, mas poucos sabem utilizá-la, posso dizer com toda propriedade que as crianças que freqüentam a Creche Oeste podem vivenciar a democracia, porque, nosso trabalho e nossa prática é oferecer-lhes ferramentas para a escolha, nosso objetivo é criar condições para que construam a autonomia e isso se dá, principalmente, quando há um espaço e profissionais que proporcionam a elas vez e voz.

A Oficina de Informação, um espaço configurado para o universo infantil, com suas almofadas em forma de cobra, tartaruga, sapo, os livros organizados à altura das crianças num trenzinho móvel, o acervo de revistas, gibis e fitas de vídeo veio consolidar o nosso respeito às crianças, veio dizer que é possível ter um trabalho de qualidade na educação infantil."

Sonia Vitória

S.P, janeiro de 2005 
Tânia, faz parte do quadro de educadores desde 1998.

"Penso o quanto é importante para formação da criança ouvir histórias. Escutálas é o início da aprendizagem para ser leitor, e não há nada de importância maior que o ensino do prazer da leitura.

Lembro-me quando eu era pequena e ouvia muitas histórias. Tantas que me faziam entrar em um mundo mágico. Eram histórias bonitas com explicações do mundo como a de meu avô que quando morreu virou uma estrela, aquela que aparecia todas as noites e com quem eu poderia conversas. Histórias que meu pai contava e me levavam ao encanto da magia, do medo do saci, do gigante $e$ cuca, os seres que apareciam no quintal. Acho que ele nem sabia, mas estava me dando a chave de abrir o mundo.

Nos primeiros anos de escola, me divertia lendo gibis, com os planos infalíveis de cebolinha ficava encantada com a aventura de Henrique e Eduardo, perdidos em uma ilha cheia de mistérios e torcia para que eles encontrassem o caminho de casa. Ler para mim foi sempre um prazer.

É ouvindo histórias que se pode sentir emoções, que descobrimos outros lugares, outras culturas, é entrar em um mundo encantado e para isso não precisa saber ler.

Em 2001, quando fiz faculdade de letras, apresentei um seminário sobre leitura. Nesta época eu trabalhava com crianças na faixa -etária de 2 anos. 
Exibi um vídeo onde estas crianças folheavam livros, uma cena de um trio em que uma delas "lê" para as outras duas. Uma outra cena em que "lê" folheando as páginas delicadamente e acompanhando com o dedinho a história que contava.

As alunas do meu curso acharam que aquilo não era possível. Como e por que levar livros para crianças tão pequenas e que nem sabiam ler? Fui discutindo $e$ pontuando a importância das histórias para as crianças. Elas aprenderam a folhear livros, a manuseá-los e a ler as imagens.

Ao ler, ajudamos a ampliar o vocabulário das crianças, a imaginação, abrimos as portas do mundo e mostramos que através dos livros podemos conhecer o universo. $O$ principal é que possamos apresentar a leitura como um prazer a ser desfrutado por nós e não ler porque alguém vai fazer perguntadas ou porque precisa responder questionários.

Por ser a leitura um momento agradável na vida destas crianças, elas mesmas escolhem os livros a serem lidos ou relidos, este é o momento de máxima gratificação.

$\mathrm{Na}$ Oficina, as crianças têm a oportunidade de selecionar os livros que procuram nas caixas coloridas. Elas estão cada vez mais apaixonadas pelos livros e por suas histórias. Uma das coisas que fazem quando chegam lá é apresentar o livro que levam pra casa aos amigos. As crianças também tomam cuidado com o livro e, quando encontram algum rasgado, nós consertamos na roda. 
O debate foi intenso, pois para as alunas do meu curso, o livro só deveria ser oferecido quando a criança começa a ler.

Recordei de como comecei a ser leitora e o quanto ouvi histórias foi importante na minha vida. Os adultos são os primeiros leitores na vida das crianças. Formar leitores significa encantá-los com o poder que vem dos livros.

Tenho certeza que uma sementinha foi lançada naquele seminário e quem sabe um dia, elas reconhecerão a importância de propiciar às crianças pequenas, o contato com o livro. Acredito que apreciar boas histórias é o melhor adubo para formar futuros leitores."

Tânia

S. P, Abril de 2005

$* * *$

\section{- Equipe Cozinha}

Raquel faz parte do quadro de funcionários da cozinha desde 1998.

"Geralmente uso a Oficina de Informações no meu horário de almoço. Acho um lugar interessante para funcionários de 8 horas pois lá temos a oportunidade de viajar, tanto na leitura de livros como no acesso à Internet podemos também relembrar o passado com fotos disponíveis a todos que sentirem saudade de momentos que passaram. 
O ambiente é bem aconchegante para quem apenas prefere descansar. Fico meio deslocada quando não posso desfrutar neste horário pois na maioria das vezes é o único que posso. Não vivi a construção deste espaço, mas hoje não vejo a Creche Oeste sem ele."

Raquel

SP, novembro de 2004

$* * *$

\section{- Equipe da limpeza}

Elenilza Fagundes, faz parte do quadro de funcionário da limpeza, desde 1992, é mãe de gêmeos que freqüentaram a Creche Oeste até o ano de 2000.

"Participo da Oficina de Informação desde o início (estou na Creche há 12 anos), para mim é um lugar fascinante, como sou apaixonada por livros sempre que posso leio um livro. Para os meus filhos que ficaram desde bebês, a Oficina teve um papel importante na vida deles, foi onde aprenderam a gostar de livros e histórias. Hoje, com 9 anos, eles continuam gostando de ler e sempre que vêm a Creche vão até as Oficina de Informação e levam livros e fitas de vídeo para casa ou pedem que eu leve para eles. Fico feliz quando vêm pessoas de outros lugares visitar a Creche e a Oficina, que já é um marco na Creche Oeste. Falo com orgulho da Oficina para as pessoas e fico feliz de ter um espaço tão importante e de qualidade para as crianças e nós funcionários."

Elenilza Fagundes

S. P, outubro de 2004 


\section{- Equipe de coordenação}

Maira Claudia Lopes da Silva, Psicóloga da Creche Oeste desde de 1996.

"Sou psicóloga e faço parte da equipe de Coordenação da Creche Oeste, desde 1996, quando passei a acompanhar o trabalho da Oficina de Informação. Nesse tempo pude presenciar muitos momentos interessantes que ocorreram nesse espaço. Sempre chamou muito a minha atenção a atração que a Oficina exercia. Desde os funcionários que optavam por aproveitar seu horário de almoço para momentos de leitura, como pais que muitas vezes ao virem buscar seus filhos subiam em sua companhia e ali contavam histórias acomodados em almofadas pelo chão. Na infância e na adolescência freqüentei escolas que ofereciam bibliotecas para seus alunos, mas em nenhuma delas encontrei essa proposta que se abre e se estende para todos, chegando a ser um espaço de possível convivência e troca entre pais e filhos. Para mim esse sempre foi o diferencial da Oficina, um espaço que se pretende democrático, em constante mudança e busca de compartilhar cultura e informação com diferentes segmentos da sociedade. Outra experiência muito interessante nesse sentido, foi a parceria que se estabeleceu com uma escola situada nas proximidades da Creche Oeste, na Comunidade São Remo. As crianças dessa escola freqüentavam a Oficina com certa periodicidade e participavam de atividades juntamente com as crianças do Pré da creche. Esses foram momentos riquíssimos de troca em todos os sentidos. Após algum tempo de convivência entre as crianças das duas instituições, tendo a Oficina como elemento de mediação, tive a grande oportunidade de acompanhar uma visita de nossas crianças à escola na São 
Remo. Lá ouvimos histórias, brincamos de roda, tomamos lanche e conversamos muito! Na saída ganhamos um presente, um grande desenho produzido pelas crianças e a mensagem de uma grande amizade. Penso que essa experiência traduzia de forma simples essa idéia tão discutida nos dias de hoje, educação e cultura para todos. A Oficina vem ao longo desses anos acumulando histórias que a transformam em um espaço onde todos são protagonistas, um espaço que nos traz boas lembranças!"

Cacau

S.P, fevereiro de 2005

****

Maire Clarie Sekkel, participou do projeto pedagógico de 1992 a 2004, no primeiro momento como psicóloga e depois como diretora da Creche Pré Escola Oeste.

"Já faz onze anos da inauguração da Oficina na Creche Oeste! Quanto tempo e quantas mudanças aconteceram. Dessa perspectiva de uma década alguns detalhes se perdem e tem até acontecimentos importantes que não vai ser possível lembrar. Mas tem algumas situações vividas que ficaram bem registradas na memória.

Lembro bem do momento que a Creche Oeste atravessava quando Iara e Edmir decidiram sobre a construção da Oficina. Eram muitas as dificuldades de relação entre crianças, educadoras, funcionários e pais. Os livros que havia na Creche estavam recolhidos, fora do alcance das crianças, para preservá-los, porque elas não tinham cuidado e destruíam tudo que lhes caía nas mãos. Acho 
que esse foi o primeiro e inesquecível aprendizado com que o Prof. Edmir nos presenteou: confiar nas crianças, na família e na comunidade, e deixar que os livros percorressem as mãos delas, mesmo que algum se rasgasse ou se perdesse. Terá valido à pena! Nossa, que verdade! No começo eu duvidei que fosse dar certo, ao mesmo tempo que sentia confiança na fala do Edmir. Como os livros estavam sendo doados pelo projeto também não havia o que temer. Esse foi um aprendizado que levo comigo desde então, e que me serviu de inspiração em muitas outras oportunidades. Aprendi que confiança gera confiança!

A Oficina foi concebida inicialmente sem a participação dos educadores da creche (que eu me lembre!), e foi apresentada a todos, como um presente, no dia da inauguração. Acredito mesmo que foi um presente muito bom, que com o tempo ganhou as marcas do uso e passou por reformas e reinvenções. Lembro que na época eu era a psicóloga da creche, e me sentia tão pouco envolvida no processo, que fui embora no meu horário no dia da inauguração!

Uma das idéias orientadoras desde o princípio é que a Oficina estivesse impecável, em todos os detalhes. Por isso houve a inauguração e a reinauguração (termo que deu margem a muitas controvérsias) um ano depois, com o mobiliário adequado e todos os detalhes planejados. $O$ cuidado estético foi sempre priorizado, junto com os cuidados nas relações. $E$ foi muito interessante perceber o poder de irradiação que tem um ambiente bem concebido e cuidado. Aprendi muito com essa experiência também: se não der para cuidar de todos os espaços é melhor concentrar os esforços em um deles e ajeitar os outros como for possível. A Oficina funcionou como fonte 
inspiradora para os educadores, e todos os espaços se transformaram ao longo desses anos. Mas, acho muito importante fazer uma ressalva: outras determinações também foram significativas nesse processo, e não é possível identificar a medida da contribuição de cada uma delas. A equipe de coordenação da creche estava passando por mudanças quando a Oficina foi inaugurada, e as barreiras que impediam os relacionamentos sofreram grandes transformações. A concepção da Oficina estava agora em sintonia com a concepção da creche, e acredito que isso foi fundamental no processo de apropriação desse projeto. A creche amadureceu, construímos um coletivo e o trabalho se tornou participativo. A experiência com os círculos de qualidade, aprendida com o Prof. Waldomiro Vergueiro, foi de valor inestimável nesse processo, no qual aprendemos a dinâmica de ir e vir do grande grupo para os pequenos grupos e depois sempre de volta para o grande grupo de novo. Essa articulação não hierarquizada entre o grande grupo e os pequenos grupos fortalece a participação, o respeito e o compromisso. Rose Mara e eu nos aprofundamos na pesquisa sobre o planejamento dos espaços, o que, sem dúvida, trouxe grande contribuição para essa reflexão na creche.

Desde a inauguração a Oficina criou a personagem Ofin, um fantoche que conversava com as crianças sobre as regras da Oficina. Nunca gostei do Ofin, achava que ele não tinha uma personalidade, e era apenas um boneco com a função de trabalhar as regras com as crianças. Eu via com olhos críticos esse uso da brincadeira para alcançar determinados fins. Com o passar dos anos o Ofin sumiu, não sei o que aconteceu com ele. 
Uma grande barreira arquitetônica teve que ser vencida na implantação da Oficina: as escadas e a distância. Sem o compromisso dos educadores não teria sido possível. Era muito lindo ver os bebês subindo as escadas, devagar, alguns engatinhando, outros no colo. E o mais interessante é que todos tinham clareza do sentido dessa atividade na rotina deles.

Passaram-se dez anos, o projeto da Oficina de Informação é hoje, creio eu, inseparável da Creche Oeste, foi apropriado, transformado e (talvez) reinventado nos espaços e rotinas. Foi uma experiência muito importante na minha trajetória acompanhar esse processo de implantação, com todas as nuanças das relações pessoais que ora erguem barreiras, ora constróem caminhos. Como dizia o Waldomiro, "a qualidade se faz com pessoas" e os projetos (assim como os livros) precisam ser tomados nas mãos!"

\section{Maire Clarie Sekkel}

S.P, abril de 2005

A possibilidade de os funcionários, especialmente os educadores, participarem das experiências promovidas pela Oficina de Informação permite evocar momentos de suas próprias infâncias, ressignificando os processos vivenciados:

É o caso da educadora que conta no seu depoimento:

"Nunca gostei de ler, sempre li por obrigação, obrigação imposta pela escola, obrigação de fazer uma prova ao término da leitura. Durante toda a minha infância, só li para a escola..." 
$\mathrm{Na}$ relação com as crianças, a mesma educadora, que antes lia somente por obrigação, descobre o prazer da leitura:

"O tempo de concentração deles é bem pequeno, como o meu era em relação à leitura, e assim, como educadora, fui descobrindo junto com as crianças, o prazer da leitura, afinal, era tão agradável e gratificante vê-los se interessar pelos livros que não tinha como não me interessar também. Aos poucos eles foram ficando mais tempo nas nossas rodas de história, e eu com os livros."

A desconstrução de concepções reducionistas, que impedem o manuseio de livros por parte de crianças bem pequenas, é evidenciada nesse trecho do depoimento de uma das educadoras:

"O fato dos livros estarem ao alcance das crianças desmistifica a nobreza/ elitização do objeto "livro" já que, aos, olhos de muitos as crianças não podem, manusear os livros, sendo "crianças não tem capacidade, cuidado, e os livros seriam rasgados, danificados."

Uma das educadoras, ao apresentar um vídeo no curso de letras, causa uma grande indignação em uma de suas colegas:

"O debate foi intenso, pois para as alunas do meu curso, 0 livro só deveria ser oferecido quando a criança começa a ler."

Ao acondicionar diversos dispositivos de informação, num determinado espaço, dúvidas aparecem :

"Ah... Nossa, tem televisão! Que legal, eu adorava ver TV quando era pequena... Mas com essa televisão aqui, será que as crianças se interessam pelos livros?". 
As educadoras assumem a responsabilidade de informar e sensibilizar os pais, sobre a chegada dos livros nos seus lares:

"Então chegou o grande momento de emprestarem livros para levar para casa, o que supunha uma parceria com os pais. Para garantir esta parceria foi feita, no espaço da Oficina, uma Reunião de Sensibilização, na qual, depois da leitura do texto "Livro: a troca" de Lygia Bojunga Nunes, os pais foram motivados a evocar memórias acerca do contato com os livros na infância, o que despertou a emoção de vários, inclusive de educadoras."

No depoimento dessa educadora, também fica evidenciado que o livro, muitas vezes, serve para mediar a relação entre criança e família, num mundo em que, cada vez mais, os pais necessitam trabalhar para sobreviver:

"Os pais, incentivados a ler com e para as crianças, cavando um espaço para isso na rotina, compreenderam que deviam valorizar o fato de o livro se fazer mediador significativo na relação entre pais e filhos."

Ao vivenciar práticas na Oficina de Informação, uma das educadoras constrói critérios de qualidade para criticar a biblioteca da escola onde, atualmente, trabalha:

"Quando levei meus alunos para escolherem livros para levarem para casa, foi uma confusão. Como nem todos os livros estavam ao alcance das crianças, elas começaram a me pedir para pegar "aquele livro lá de cima"! Então eu começo perguntando: "É esse? Não? Então é esse?"

O desconhecimento da forma de classificação dos livros no espaço da biblioteca acima citada, dificulta, para crianças e educadora, o encontro dos títulos desejados: 
"Quando uma aluna me perguntou: "Onde está o livro da Pequena Sereia que eu vi outro dia?", tive que responder "Não faço a menor idéia, temos que procurar por toda a biblioteca".

A importância do papel da educadora da Oficina de Informação é lembrado por uma delas, a partir da nova experiência:

"Se um livro está fora do lugar é porque ele foi lido, porque alguém passou por lá, e como muitas pessoas passam por lá, existe a educadora responsável por esse espaço."

A construção do projeto da Oficina de Informação proporcionou diversas reflexões sobre os dispositivos de informação, ampliando os conhecimentos dos educadores:

"Nós educadoras só tivemos a ganhar com esse investimento, pois, ampliamos através de várias formações continuadas, o nosso conhecimento sobre literatura, gibis e filmes infantis, passamos compreender cada vez mais o universo das crianças, por meio dessa comunicação, dessa troca de experiências pudemos modificar também muitas de nossas atitudes e adquirir uma postura mais sólida $e$ profissional no trabalho junto às crianças."

A possibilidade de os educadores tornarem-se multiplicadores da concepção da Oficina de Informação aparece como realidade, na seguinte narração:

"Hoje no meu novo trabalho fui chamada para ajudar na organização da Biblioteca do Fundamental I (1 a 4 séries) que coincidência, coisa do destino... fui dando idéias, contando minhas experiências vividas na Creche, e hoje olho para esse espaço e vejo a extensão da Oficina de Informação." 
O orgulho de a Creche Pré/ Escola Oeste possuir um projeto inovador é registrado no depoimento da funcionária da limpeza:

"Fico feliz quando vem pessoas de outros lugares visitar a Creche e a Oficina, que já é um marco na Creche Oeste. Falo com orgulho da Oficina para as pessoas e fico feliz de ter um espaço tão importante e de qualidade para as crianças e nós funcionários"

O espaço da Oficina de Informação integra-se na Creche Oeste, de acordo com o depoimento da funcionária da cozinha:

"Não vivi a construção deste espaço, mas hoje não vejo a Creche Oeste sem ele."

Uma das diferenças do dispositivo de informação, em relação a outras bibliotecas escolares, é traduzida no depoimento da psicóloga da Creche:

"Na infância e na adolescência freqüentei escolas que ofereciam bibliotecas para seus alunos, mas em nenhuma delas encontrei essa proposta que se abre e se estende para todos, chegando a ser um espaço de possível convivência e troca entre pais e filhos."

A Oficina de Informação abre as portas para uma escola de Educação Infantil bem próxima da Creche Oeste; inúmeras descobertas vão se dando nessa nova relação:

"Após algum tempo de convivência entre as crianças das duas instituições, tendo a Oficina como elemento de mediação, tive a grande oportunidade de acompanhar uma visita de nossas crianças à escola na São Remo." 
Diversos depoimentos dos funcionários da Creche/ Pré Escola Oeste evidenciam a importância desse tipo de dispositivo de informação no processo educativo de crianças, pais, funcionários e educadores. A seguir, um desses relatos:

"É, a Oficina de Informação é mais que uma "biblioteca bonitinha". Acredito que é um espaço que vai além de TER e OFERECER livros, revistas, gibis, filmes, CDs, fotos, televisão, computador, aparelho de som para as crianças. A Oficina não é só um espaço, mas parte de uma proposta de Educação. Pude ver e vivenciar uma proposta que se preocupa com a RELAÇÃO que o indivíduo estabelece com tudo aquilo que a Oficina oferece. $E$ um espaço cuidadosamente criado para promover ENCONTROS, encontros entre pessoas e entre estas com o mundo por intermédio das diversas mídias (não sei se é o termo correto) que ele oferece. É uma proposta que é desfrutada não só pelas crianças, mas por toda a comunidade escolar." 
PARTE IV 


\title{
Conclusões
}

\begin{abstract}
Ser, sentir, brincar, expressar-se, relacionar-se, mover-se, organizar-se, cuidar-se, agir, e responsabilizar-se são partes do todo de cada indivíduo, menino ou menina, que desde bebê vão, gradual e articuladamente, aperfeiçoando estes processos nos contatos consigo próprios, com as pessoas, coisas e o ambiente em
\end{abstract}

geral.

Regina Alcântara de Assis

Ao relembrar meu percurso profissional na área de Educação, percebo que ele possibilitou a ampliação de meu universo pessoal no que diz respeito a conhecimentos, sonhos e lutas. Participar de uma proposta pedagógica com qualidade e sensibilidade, fruto de ações coletivas, é um verdadeiro privilégio, para quem, um dia, ainda menina, indignou-se com situações do cotidiano escolar, a partir de suas próprias experiências.

A pesquisa e a experiência vividas na Oficina de Informação da Creche/Pré Escola Oeste possibilitaram a constatação da importância desse dispositivo informacional, num mundo em constante transformação. Assim, a minha participação no projeto proporcionou um novo olhar sobre a pedagogia da infância. Esse tipo de dispositivo não é "um luxo", mas sim uma necessidade dos novos tempos. O acesso e apropriação dos conteúdos culturais: da arte, da ciência, da filosofia, da tecnologia, dos mitos e de saberes cotidianos, a participação em sua produção devem ser compreendidos como direito de todos, independentemente da classe social e de outros condicionantes. 
Compreende-se que cada instituição esteja inserida num determinado contexto, com suas especificidades e particularidades, porém, entendemos que essa experiência relatada e vivida, tecida a várias mãos, poderá contribuir com conceitos e metodologias, visando o diálogo com o patrimônio acumulado, inspirando políticas públicas e novas práticas na Educação Infantil.

Vale lembrar que a finalidade da educação é promover a formação integral das crianças, nos vários aspectos: físicos, emocionais, afetivos, cognitivos, sociais, éticos e estéticos. E, para que as crianças e suas famílias sejam inseridas em uma vida plena de cidadania, é necessário contemplar nas Propostas Pedagógicas de Educação Infantil, de acordo com as Diretrizes Curriculares Nacionais para a Educação Infantil (1998), os seguintes fundamentos:

a. Princípios Éticos da Autonomia, da Responsabilidade, da Solidariedade e do Respeito ao Bem Estar Comum;

b. Princípios Políticos dos Direitos e Deveres de Cidadania, dos Exercícios da Criticidade e do Respeito à Ordem Democrática;

c. Princípios Estéticos da Sensibilidade, da Criatividade, da Ludicidade, da Qualidade e da Diversidade de Manifestações Artísticas e Culturais.

Assim, recuperando os princípios referendados pelas Diretrizes Curriculares Nacionais para a Educação Infantil, em consonância com a Proposta Pedagógica da Creche/Pré Escola Oeste, e relacionando-os com o objetivo desta dissertação de mestrado, apresentamos alguns pressupostos básicos, elaborados a partir da experiência e da reflexão: desconfinamento espacial, social e cultural, construção de autonomia e afetividade. Apesar de os pressupostos básicos estarem separados nesse momento, é fundamental registrar que se acham intimamente relacionados. Dessa forma, buscamos evidenciar a importância da Oficina de Informação no processo educativo das crianças, dos funcionários, dos educadores, entrelaçando-a com a proposta pedagógica da Creche/Pré Escola Oeste. 


\section{Desconfinamento espacial, social e cultural}

Ao considerar que as crianças bem pequenas estão inseridas em instituições educativas, o desconfinamento espacial, social e cultural faz-se necessário nas propostas pedagógicas. A Oficina de Informação contribui, assim, para ampliar o universo infantil, ao somar suas atividades com as demais práticas da Creche /Pré Escola Oeste.

\section{- Espacial}

A possibilidade de a Creche oferecer mais um espaço coletivo, por meio da Oficina de Informação, propicia o diálogo não só entre as crianças, mas entre toda a comunidade (interna e externa), com a cultura e o conhecimento. Se esse ambiente tivesse sido organizado somente nas salas de atividades das crianças, os adultos que trabalham na Creche e outros segmentos dificilmente teriam esse tipo de participação. Desta forma, a Oficina de Informação rompe com ambientes especializados. De acordo com o depoimento de uma funcionária:

"Para mim esse sempre foi o diferencial da Oficina, um espaço que se pretende democrático, em constante mudança $e$ busca de compartilhar cultura $e$ informação com diferentes segmentos da sociedade."

O conjunto de sujeitos sociais com suas ações diversas e diferentes, que educam as crianças, também tem o direito de desfrutar da cultura e do conhecimento.

No diálogo com o espaço da Oficina de Informação, as salas de atividade das crianças de 4 meses a 6 anos e 6 meses foram se transformando para acolher os livros escolhidos quinzenalmente, por educadoras e crianças. As educadoras passaram, assim, a delimitar um espaço nas salas para receber os livros, criando um ambiente acolhedor e aconchegante que redefinia o espaço educativo, como relata essa educadora: 
"O Ofin, fantoche habitante ilustre da Oficina, foi à sala conversar com as crianças e convidá-las para emprestar livros. Foi grande a euforia! Então demos início à construção de um espaço mágico na sala para a colocação dos livros: a "Tenda dos Livros", feita com tules coloridos, bolsões de tecido na parede, tapete e almofadas."

Apesar de a Oficina de Informação estar distante das salas de atividades, as marcas materiais e simbólicas do espaço circulam, desconfinadamente, por toda a Creche, aproximando os adultos e, principalmente, as crianças, dos livros.

A disposição do mobiliário e a organização do ambiente na Oficina de Informação favorecem a expressão de diferentes posturas corporais, pois quando as crianças desenham, assistem a fitas de vídeo, ou mesmo lêem um livro, fazem-no de diferentes maneiras, atendendo a desejos do corpo e não a posturas padronizadas, como revela um dos depoimentos de adolescente:

"Eu, particularmente, gostava de deitar nos confortáveis "puffs" estampados para assistir aos filmes que eram colocados pelas educadoras. Elas sempre sugeriam uma olhada nos livros das estantes para que levássemos algum, mas eu sempre ia direto para os "puffs" torcendo para que o meu pai se atrasasse para vir me buscar."

Gradativamente, as crianças vão aprendendo a controlar suas ações e a necessidade de variar constantemente suas posições corporais diminui. Mesmo assim, compreende-se que a corporalidade é um elemento essencial na forma como as crianças apreendem o mundo; por isso, não pode ser formatada. À criança devem ser oferecidos diferentes convites a novos posicionamentos corporais. 


\section{- Cultural}

Relacionar-se com o mundo não significa assimilar passivamente seus valores, suas práticas, suas ações. Ao contrário, a relação deve pautar-se no diálogo, pela reflexão, pela negociação dos valores e das práticas sociais. Um exemplo disso pode ser dado por um episódio, envolvendo a Oficina de Informação, numa atividade que a Creche Pré-Escola propõe às crianças no último grupo de permanência em seu espaço. Assim, estas são levadas a visitar escolas de ensino fundamental para que possam conversar com os professores, coordenadores e alunos, satisfazendo curiosidades e dúvidas, já que no ano seguinte deverão ser transferidas para tais escolas:

"Em uma dessas visitas, as crianças perguntaram para a coordenadora pedagógica: "Onde está a Oficina de Informação?"Ela, evidentemente, não compreendeu. Então uma das educadoras traduziu: "É um espaço semelhante a uma Biblioteca". A coordenadora, rapidamente, pegou um molho de chaves e levou o grupo até um local protegido com grades, que era a biblioteca. As crianças ficaram felizes, mas logo tiveram uma grande decepção ao contemplarem o espaço. "Isso não é Oficina! não têm almofadas, caixas de livros, televisão, vídeo..." A coordenadora da escola respondeu: "Lógico que temos livros, estão nas estantes". As crianças se dirigiram até elas, mas logo foram advertidas: "Essa não é a estante para idade de vocês."

A ampliação do repertório cultural das crianças aparece em vários depoimentos dos pais:

"Mãe senta aí, olha "o morango silvestre maduro", eu vou contar pra você, mãe "os pingos", mãe "chapeuzinho vermelho", "Rapunzel" e já aconteceu de eu estar com alguma pressa e dizer para ele contar só um pedacinho, mas ele insiste em terminar a história e quando não 
lembra uma parte, pede para ler essa página que ele esqueceu."

\section{- Social}

A possibilidade de convívio social proporciona às crianças e aos adultos aprendizagens diversas de relacionamentos com as diferenças de opiniões, temperamentos, usos, costumes e culturas. A parceria que se estabeleceu entre a Creche Pré-Escola Oeste e a Escola localizada na favela São Remo, possibilitou encontros entre classes sociais diferentes:

"E, pela primeira vez, a maioria das crianças da Creche/Pré Escola Oeste adentrou em uma favela, exceto as três crianças que moravam no local. Os dois meninos, orgulhosos, mostraram o caminho para chegar na comunidade São Remo. Tudo era uma grande novidade para aquelas crianças - a rua com várias barracas de doce e aguardente e as carroças de cavalos circulando."

Abrir a Oficina de Informação para a comunidade do entorno possibilitou um elo entre iguais e diferentes - meninos e meninas, alguns muito pobres, outros nem tanto. As experiências compartilhadas entre Creche e comunidade permitem dizer que é perfeitamente possível estabelecer um verdadeiro diálogo entre diferentes: às crianças das diferentes classes sociais foi possibilitado desconfinar-se, desconsiderando os muros que separam a São Remo da Universidade, sem ameaças, em experiências diversas de alguns episódios que, infelizmente, marcaram, em momentos anteriores, essa relação. Assim, o dispositivo de informação não só insufla vida no mundo, como também é insuflado por tudo aquilo que constitui sua essência: cor, cheiro, sabores, sentidos, memória, lembranças, invenções, vivências. 
A Oficina de Informação foi resultado de uma ação coletiva que envolveu diversos segmentos da Creche e da comunidade: crianças, pais funcionários, educadores, pesquisadores, voluntários, evidenciando a relevância dessa parceria para conceber a proposta e manter seus princípios, após dez anos de sua existência.

Tanto os depoimentos, quanto o percurso dos 10 anos de Oficina de Informação evidenciam que as relações entre Informação e Educação nos termos de propostas contribuiem, de forma decisiva, na construção de conhecimentos, valores, atitudes, por parte das crianças e adultos, frente ao mundo em que vivem.

É preciso reconhecer que a implantação desse projeto num ambiente como o da Creche Pré-Escola Oeste - que possui princípios de Educação democrática e uma política de formação em serviço - favoreceu avanços significativos no processo educativo. Na parceria entre Creche e PROESI, os descompassos entre adultos e seus pontos de vistas foram aparecendo, mas não conseguiram gerar grandes dissensões, porque se tornaram irrelevantes diante de tudo o que era expresso pelas crianças. Com seus interesses indisfarçáveis, suas manifestações, suas aprendizagens e mobilizações apaixonadas, elas foram demonstrando 0 significado essencial da Oficina de Informação na sua Educação.

\section{Construção de autonomia Cultural}

A construção da autonomia intelectual e moral é extremante relevante no processo de formação de crianças que vivem na e para uma Sociedade Democrática. Várias ações são planejadas na Creche/Pré Escola Oeste para que as crianças possam exercitar o pensamento, levantando hipóteses, resolvendo problemas, utilizando, assim, as formas diversas de representação e comunicação. A construção de valores é outro princípio que norteia as ações das crianças na Creche. 
Contribuindo com as ações acima citadas, os grupos da Creche participam, formalmente, da Oficina de Informação, duas vezes por semana. Ali têm oportunidades de desenvolver aprendizagens culturais, mobilizadas à construção de autonomia nos processos de conhecimento e cultura.

No período da manhã, utilizam os vários dispositivos de informação para pesquisar assuntos que estão atrelados ao projeto de trabalho desenvolvido na sala de atividades. Já no período da tarde, sobem à Oficina para escolher livros a serem levados para casa e também para a classe. Atualmente, as crianças têm um tempo maior para escolher os livros e sugeri-los aos amigos. Quando existe possibilidade, ouvem histórias propostas pela educadora da Oficina de Informação ou assistem a uma fita de vídeo. As escolhas dos livros, tanto para sala, quanto para o domicílio, são realizadas pelas próprias crianças que as fazem "de corpo inteiro". A pele roça as texturas do livro, percebendo áreas macias, rugosas, que disparam sensações táteis. Um livro aberto inspira ser um chapéu sobre a cabeça, enquanto olhos buscam imagens e cores. Ouvidos, mãos, dedos, olhos, pernas e pés encontram-se em movimentos contínuos, às vezes mais leves, às vezes mais bruscos, traduzindo a liberdade de escolha, a possibilidade de trocas e, ou mesmo, momentos íntimos, confidentes.

No diálogo entre Creche, Cultura e família, as crianças aprendem a trocar informação sobre o acervo de livros da Oficina de Informação:

"Quando meu filho mais novo começou a freqüentar a creche, eu me perguntava se ele teria o mesmo gosto pelos livros que o irmão? Por ser mais agitado em casa, imaginava que talvez os interesses dele fossem ser outros menos literários e mais esportivos. Grande engano, a ida para a "Oficina de Informação" é para ele uma aventura, Jorge você viu o livro do bumbum? Perguntava para o irmão." 
Aprendem também, a compartilhar os livros escolhidos na Oficina de Informação, e a se responsabilizar pelo objeto. O depoimento da menina que veio visitar a Creche junto com a Escola Alô-Alô, comprova o papel da biblioteca no processo educativo, não só das crianças que estão inseridas na instituição, mas de amigos, parentes e vizinhos de seu convívio:

"Aqui nessa creche fica o meu primo, eu já li vários livros que ele trouxe da creche para minha casa."

As crianças, na relação com os livros, constroem valores fundamentais de cidadania, indignam-se com atitudes de destruição frente ao objeto. Essa relação ficou nítida em um episódio que ocorreu no G2:

"a Creche recebeu uma criança nova no G2. Quando ela avistou os bolsões com os livros, aproximou-se, pegou um deles e logo foi rasgando-o. As crianças por volta de 2 anos e 5 meses, que já tinham um contato intenso com os livros no berçário, imediatamente correram ao encontro da educadora para mostrar a gravidade da situação."

Se, porventura, as crianças rasgam os livros, são encorajadas a reparar sua ação; da mesma forma, caso encontrem os objetos danificados, são convidadas a recuperá-los. Mesmo compreendendo que tais intercorrências acontecerão na relação entre os pequenos leitores e os objetos, é fundamental que os adultos atuem no sentido de que as crianças aprendam a assumir suas ações, reparando seus atos em caso de necessidade, numa atitude de preservação do patrimônio público:

"As crianças também tomam cuidado com o livro e, quando encontram algum rasgado, nós consertamos na roda." 
Na relação com os livros, uma mãe constata que seu filho é capaz de nomear os autores das histórias infantis. Essa aprendizagem é vislumbrada pelos membros da família:

"Quando Jorge estava no berçário gostava de algumas histórias, mas o que mais chamou nossa atenção neste período foi o fato de lembrar o nome dos autores. Ainda hoje posso lembrar dele pequeno dizendo: Mãe olha! Este livro é da Mary França e do Eliardo França. Até hoje ele pergunta o autor de alguns livros do seu interesse como Harry Potter."

Esses e outros episódios permitem-nos afirmar que a Oficina de Informação tem contribuído para o desenvolvimento da autonomia; as crianças percebem-se capazes e são, cotidianamente, encorajadas a agirem e responderem por si mesmas.

\section{Afetividade}

A relação interpessoal (comunidade, crianças, pais, funcionários,) que se estabelece no cotidiano das instituições educativas poderá promover, ou não, interações carregadas de significado com o mundo, pois são permeadas por relações também estabelecidas com o conhecimento. No dia 17 de novembro de 2004, o jornal "Folha de São Paulo" publica uma reportagem sobre um menino de 7 anos que é punido pela professora por ter esquecido de devolver o livro à biblioteca. O castigo foi ficar atrás da porta da sala de aula, e o pior, esqueceramno por mais de 4 horas, após a escola estar fechada. Se consideramos as reformas educacionais ocorridas ao longo da história, essa atitude é um verdadeiro contra-senso na/para uma sociedade democrática com tantos dispositivos legais que amparam o cidadão brasileiro e, em especial, a criança. 
Que tipo de relação essa criança estabelecerá com a escola, a biblioteca, o livro e o conhecimento?

A relação de confiança faz-se necessária nesse processo de interação do leitor com o objeto livro. As crianças na Creche Pré-Escola Oeste, quando esquecem, eventualmente, os livros em suas casas, não são punidas e nem necessitam ressarcir financeiramente o atraso pela devolução, como ocorre em algumas instituições educativas. Nessa relação entre sujeito e objeto, a criança é mais importante no processo, pois sem o leitor, não há leitura. Embora admitamos problemas, a Creche realiza diversas ações respeitosas no sentido de as crianças cuidarem dos materiais de uso coletivo; afinal, dentre as várias competências de um leitor, preservar o livro também faz parte desse processo educativo.

Apesar de a Creche Pré-Escola Oeste já trabalhar embasada na concepção de que, para as crianças ficarem tranqüilas e poderem desfrutar do ambiente da Creche, é importante construir vínculos de confiança com as famílias, aprendeuse com a Oficina de Informação, outras formas de relacionamento com a comunidade, através de novas ações que foram propiciadas e evidenciaram-se em relatos, como o que se segue:

"Eram muitas as dificuldades de relação entre crianças, educadoras, funcionários e pais. Os livros que havia na Creche estavam recolhidos, fora do alcance das crianças, para preservá-los, porque elas não tinham cuidado $e$ destruíam tudo que lhes caía nas mãos. Acho que esse foi - primeiro e inesquecível aprendizado com que o Prof. Edmir nos presenteou: confiar nas crianças, na família e na comunidade, e deixar que os livros percorressem as mãos delas, mesmo que algum se rasgasse ou se perdesse... Aprendi que confiança gera confiança!"

Para finalizar, vale lembrar que de todas as evidências do aprendizado obtido com a Oficina de Informação, devido à política administrativa à qual está vinculada a 
Creche Pré/Escola Oeste, não foi possível investir, da forma como desejávamos e avaliávamos ser necessária, na ampliação e reposição de aparelhos eletrônicos e materiais tais como: livros, cds, fitas de vídeo, cd-rom e computadores, dificultando ou mesmo empobrecendo, muitas vezes, o desenvolvimento de determinadas propostas. Na tentativa de solucionar alguns desses problemas, a Creche junto com a associação de pais, organizou campanhas para conseguir recursos financeiros, ou mesmo materiais. Além disso, a informatização da Oficina de Informação foi completamente paralisada com a saída da equipe do PROESI.

Para estabelecer relações entre Informação e Educação, num mundo cada vez mais informatizado, aprendemos, com essa experiência, que há necessidade de uma política de ampliação e reposição para obter recursos necessários para o desenvolvimento do trabalho educativo, pois estas implicam em considerar novas formas de relações pedagógicas no ato de ensino-aprendizagem. Ainda assim, os depoimentos mostram a importância desse dispositivo no processo educativo não só das crianças, mas de todos os que participaram direta ou indiretamente do projeto.

Neste momento, arrisco-me a terminar essas considerações finais, utilizando novamente dois depoimentos: o de uma educadora que trabalhou apenas três anos na Creche/Pré Escola, que, mesmo não participando da implantação do projeto, traduziu em seu relato, o esforço coletivo da construção de um dispositivo de Informação num ambiente de Educação Infantil. O outro depoimento é de um adolescente que freqüentou a Creche na sua infância, em que é interessante perceber as marcas da Creche/Pré Escola Oeste, a percepção de sua importância e a clareza de que essa experiência deveria estar presente na história de todas as crianças.

"É, a Oficina de Informação é mais que uma "biblioteca bonitinha". Acredito que é um espaço que vai além de TER 
e OFERECER livros, revistas, gibis, filmes, CDs, fotos, televisão, computador, aparelho de som para as crianças. A Oficina não é só um espaço, mas parte de uma proposta de Educação. Pude ver e vivenciar uma proposta que se preocupa com a RELAÇÃO que o indivíduo estabelece com tudo aquilo que a Oficina oferece. É um espaço cuidadosamente criado para promover ENCONTROS, encontros entre pessoas e entre estas com o mundo por intermédio das diversas mídias (não sei se é o termo correto) que ele oferece. É uma proposta que é desfrutada não só pelas crianças, mas por toda a comunidade escolar."

Kamila Rumi Toyofuki

"É com base nisso que gostaria de terminar expressando a minha profunda tristeza em saber que parte das crianças, e uma parte significativa delas, não desfruta dessa passagem em suas infâncias, um momento único e tão pessoal na vida de cada uma delas, não importando cor, raça ou nacionalidade."

Gustavo Henrique C. Finotti 
PARTE V 


\section{Bibliografia}

ACHARD, P. Papel da memória. Campinas, São Paulo: Pontes, 1999.

AMARO, R. K. O. F. Biblioteca Interativa: concepção e construção de um serviço de informação em ambiente escolar. São Paulo: ECA/USP, 1998. Tese de Doutoramento.

ARROYO, M. Introdução. In: VEIGA, Cynthia Greive. Infância no Sótão. Belo Horizonte: Autêntica, 1999.

AZANHA, J.M. Uma idéia de pesquisa educacional. Edusp/ Fapesp,1992.

BACHELARD, G. A Poética do Espaço. São Paulo: Martins Fontes, 2000.

BAJARD, E. Ler e dizer : compreensão e comunicação do texto escrito. São Paulo: Cortez, 1994.

BOFF, L. Saber Cuidar - Ética do Humano- Compaixão pela Terra. Rio de Janeiro: Vozes, 2000.

BETHELHEIM, B. A psicanálise dos contos de fadas. Porto Alegre: Artes Médicas, 1997.

BRASIL. Ministério da Educação e do Desporto/ Conselho Nacional de Educação - Câmara de Educação Básica. Diretrizes Curriculares Nacionais para a Educação Infantil. Brasília, 17 de dezembro de 1998.

BRASIL. Ministério da Educação e do Desporto. Secretaria de Educação Fundamental. Referencial Curricular Nacional. Brasília: MEC/SEF, 2000, 3v.

Constituição Federal. Brasília, 6 de outubro de 1988.

Estatuto da Criança e do Adolescente. Lei 8.069/90.

Subsídios para credenciamento de instituição infantil. Brasília: MEC/SEF,1998, 2v.

BRUNER, S.J. Atos de significação. Porto Alegre: Artes Médicas, 1997.

CAMARGO, Aspásia. História Oral e Política. In: MORAES, Marieta de (org.). História Oral e Multidisciplinariedade. Rio de Janeiro: Diadorim, 1994. 
CARVALHO, E. A. Apresentação. In: MORIN, E. Os setes Saberes necessários à Educação do Futuro. São Paulo: Cortez, 2002.

CHARTIER, R. Práticas de leitura. São Paulo: Estação Liberdade, 1996.

CORTELLA, M. S. A escola e o conhecimento: fundamentos epistemológicos e políticos. 4 ed. São Paulo: Cortez, 2001.

DELANNOY, J.P. Guia para a transformação das bibliotecas escolares. Lisboa, Livros Horizonte, 2000.

DIAS, M. C.M. Metáfora e pensamento; considerações sobre a importância do jogo na aquisição do conhecimento e implicações para a educação pré-escolar. In: KISHIMOTO, T. (org). Jogo, Brinquedo e Brincadeira e a Educação. São Paulo: Cortez, 1996.

DIAS, M. C. M..Saberes Essenciais ao Educador da Primeira Infância: uma Reflexão na Perspectiva dos Protagonistas. Tese de Doutorado, FEUSP, 1997.

Metáfora e Pensamento: Considerações sobre a Importância do Jogo na Aquisição do Conhecimento e Implicações para a Educação Pré-escolar.

FARIA, I. P. Estação Memória: lembrar como projeto.Contribuições ao estudo da mediação cultural. São Paulo, 1999. (Dissertação de mestrado apresentada à ECA/USP)

FREIRE, M. Rotina: Construção do tempo na relação pedagógica. São Paulo: Espaço Pedagógico, 1998.

FORNEIRO, L I. A organização dos espaços na Educação Infantil. In ZABALZA. M. Qualidade em Educação infantil. Porto Alegre: ArtMed, 1998.

GALVÃO, I. Henri Wallon. Uma concepção dialética do desenvolvimento infantil. Petrópolis, RJ: Vozes, 1995.

GALVÃO, I. A questão do movimento no cotidiano de uma pré-escola. Caderno de pesquisa, São Paulo, 1996, n.98.

GOZZI, R. M ; SEKKEL, M. C. O espaço: Um parceiro na construção das relações entre as pessoas e conhecimento. In: Dias, M.C.M \& NICOLAU, M.L.M. (org.) Oficinas de Sonho e Realidade na Formação do Educador da Infância. São Paulo: Papirus, 2003.

GOZZI, R.M. Formação de leitores, espaço de leitura e comunidade. Disponível em http:// www.tvebrasil.com.br/salto/boletins/el/tetx4.htm. Acesso em 25 de outubro de 2004.

JOSSO, M.C. Experiências de Vida e Formação. São Paulo: Cortez, 2004. 
KAMII, C. A criança e o número. Campinas: Papirus, 1989.

KISHIMOTO, T. M. Formação de Profissionais de Creches no Estado de São Paulo 1997 - 1998. São Paulo: Fund. Orsa, 2000.

LEITE FILHO, A. Proposições para uma Educação Infantil Cidadã. IN: GARCIA, R. L. ; LEITE FILHO, A. (org). Em defesa da Educação Infantil. Rio de Janeiro: DP\&A, 2001.

LÉVY, P. Cibercultura. São Paulo: Ed.34, 1999.

MATTOS, Y. Histórico das creches da Universidade de São Paulo. Divisão de Creches: Relatório de atividades, 1990, p. 3-5.

MICHAELIS: Dicionário escolar língua portuguesa. São Paulo: Editora Melhoramentos, 2002.

MORIN, E. A cabeça bem-feita: repensar a reforma, reformar o pensamento. Rio de Janeiro: Bertrand Brasil, 2000.

Ciência com consciência. Rio de Janeiro: Bertrand Brasil, 1999.

Cortez, 2000.

Os sete saberes necessários à educação do futuro. São Paulo:

OBATA, R. K. (v.t. AMARO, Regina Keiko O. F). Biblioteca Interativa: construção de novas relações entre Biblioteca e Educação. R. bras. Bibliotecon. Doc. São Paulo, Nova Série, 1999, p.91-103.

OLIVEIRA, Z. R. Educação Infantil: fundamentos e métodos. São Paulo: Cortez, 2002.

PERAYA, D. O Ciberespaço: Dispositivo de Comunicação e de Formação Midiatizada. In: ALAVA, Séraphin \& Colaboradores. Ciberespaço e formações abertas. Rumo a Novas Práticas Educacionais? Porto Alegre: Artmed, 2002.

PERRENOUD, Ph. Construir as competências dentro da escola. Porto Alegre: Artmed, 1999.

PERROTTI, E. Confinamento cultural, infância e leitura. São Paulo: Summus, 1991.

E. Projeto integrado: Biblioteca Interativa e Educação: um novo paradigma em Ciência da Informação. São Paulo: CBD/ECA/USP, 1996. (Relatório apresentado ao CNPq), 
E. Leitores, ledores e outros afins (apontamentos sobre a formação ao leitor). In Prado, J (org.) A Formação de leitor: pontos de vista. Rio de Janeiro: Argus, 1999, p.36

E. Ementa do curso de pós graduação: Informação e Educação: Teoria e Prática. São Paulo, 2004.

PINTO, M. \& SARMENTO, M. J. (org.) As crianças: Contextos e Identidades. Portugal - Minho: Universidade de Minho, 1997.

RODARI,G. Introdução. In: TONUCCI, F. Com olhares de criança. Porto Alegre, Artes Médicas, 1997.

ROSEMBERG, F. O movimento de mulheres e a abertura política no Brasil: 0 caso da creche. In: Creche. Cortez/FCC,1989, p.90-103.

RUSSELL, Bertrand. O Elogio ao Ócio. Rio de Janeiro: Sextante, 2002.

SANCHES, E. C. Creche: realidade e ambigüidades. Petrópolis - RJ: Vozes, 2003.

SATO, L ; SOUZA, M. P.R de. Contribuindo para desvelar a complexidade do cotidiano através da pesquisa etnográfica em psicologia. In: Psicologia USP. Vol.12, n.2. São Paulo - IP, 2001.

SEKKEL, M. C. Reflexão sobre a experiência com a Educação Infantil: Possibilidades de uma Educação contra a violência na primeira Infância. Dissertação apresentada ao Instituto de Psicologia, Universidade de São Paulo, 1998.

SERRÃO, C. R. B. O tempo na Educação Infantil: Rotinas In: Dias, M.C.M \& NICOLAU, M.L.M. (org.) Oficinas de Sonho e Realidade na Formação do Educador da Infância. São Paulo: Papirus, 2003.

TONUCCI. F. Com olhos de crianças. Porto Alegre: Artes Médicas, 1997.

VIRILIO, P. Estratégia da decepção. São Paulo: Estação Liberdade, 2000.

VYGOTSKY, L.S. A formação social da mente. São Paulo: Martins Fontes, 1991.

WALLON, H. Psicologia e educação da criança. Lisboa, Veja Universidade, 1979.

ZABALZA. M. Qualidade em Educação infantil. Porto Alegre: ArtMed, 1998. 